\title{
The role of adenosine monophosphate activated protein kinase in luteal progesterone production
}

\author{
Elizabeth Compton Bowdridge
}

Follow this and additional works at: https://researchrepository.wvu.edu/etd

\section{Recommended Citation}

Bowdridge, Elizabeth Compton, "The role of adenosine monophosphate activated protein kinase in luteal progesterone production" (2015). Graduate Theses, Dissertations, and Problem Reports. 5241.

https://researchrepository.wvu.edu/etd/5241

This Dissertation is protected by copyright and/or related rights. It has been brought to you by the The Research Repository @ WVU with permission from the rights-holder(s). You are free to use this Dissertation in any way that is permitted by the copyright and related rights legislation that applies to your use. For other uses you must obtain permission from the rights-holder(s) directly, unless additional rights are indicated by a Creative Commons license in the record and/ or on the work itself. This Dissertation has been accepted for inclusion in WVU Graduate Theses, Dissertations, and Problem Reports collection by an authorized administrator of The Research Repository @ WVU.

For more information, please contact researchrepository@mail.wvu.edu. 


\title{
The role of adenosine monophosphate activated protein kinase in luteal progesterone production
}

\author{
Elizabeth Compton Bowdridge
}

\author{
Dissertation submitted \\ to Davis College of Agriculture, Natural Resources and Design \\ at West Virginia University \\ in partial fulfillment of the requirements for the degree of \\ Doctor of Philosophy \\ in \\ Reproductive Physiology
}

\author{
Jorge A. Flores, Ph.D., Chair \\ Melanie J. Clemmer, Ph.D., HCLD \\ Robert A. Dailey, Ph.D. \\ E. Keith Inskeep, Ph.D. \\ Michael Vernon, Ph.D., HCLD \\ Jianbo Yao, Ph.D.
}

Division of Animal and Nutritional Sciences

Morgantown, West Virginia

2014

Keywords: corpus luteum, bovine, luteal regression, AMPK, human granulosal cells, progesterone

Copyright 2014 Elizabeth Compton Bowdridge 


\section{Abstract \\ The role of adenosine monophosphate activated kinase in luteal progesterone production}

\section{Elizabeth Compton Bowdridge}

Prostaglandin $\mathrm{F}_{2}$ alpha $\left(\mathrm{PGF}_{2 \alpha}\right)$ has in vivo luteolytic actions on the bovine corpus luteum (CL). Although $\mathrm{PGF}_{2 \alpha}$ is utilized extensively in livestock to synchronize estrus, its actions in vitro are controversial and do not always result in a reduction in progesterone (P4) secretion. The mechanism of action of $\mathrm{PGF}_{2 \alpha}$ is thought to involve activation of the phospholipase $\mathrm{C}-\mathrm{Ca}^{2+}$ pathway. The luteolytic actions of PGF2 $\alpha$ are mediated through an elevation of cytosolic $\mathrm{Ca}^{2+}$ involving activation of protein kinase $\mathrm{C}$ (PKC). Expression of $\mathrm{PKC}$ isozymes and calcium/calmodulin-dependent protein kinase kinase 2 (CAMKK2) change as the CL develops to a mature stage. Either CAMKK2 directly affects steroidogenesis or works indirectly through an intermediary step, such as adenosinemonophosphate kinase (AMPK), which is activated through CAMKK2 targeted phosphorylation. Specifically, the hypothesis that activation of $\mathrm{PGF}_{2} \alpha$ receptor (FP) in the mature CL involves AMPK was examined. Expression of mRNA encoding a potential target AMPK for the action of CAMKK2, was increased in the mature versus developing CL. Furthermore, activation of FP induced rapid phosphorylation of AMPK. An AMPK-specific inhibitor, dorsomorphin dichloride (DM), eliminated effects of $\mathrm{PGF}_{2} \alpha$ on secretion of $\mathrm{P} 4$, supporting the hypothesis that activation of the FP receptor in mature CL involves participation of AMPK. Furthermore, in vitro two AMPK activators, 5-aminoimidazole-4-carboxamide ribonucleotide (AICAR) and metformin, decreased basal P4 secretion in mature but not in developing CL. Effect of FP activation on cholesterol transport in the mature CL was investigated. Both serum and luteal P4 declined as soon as 2 hours after $\mathrm{PGF}_{2 \alpha}$ administration, which was paralleled by a decrease in protein concentration of low density lipoprotein receptor (LDLR). Human mural granulosal cells are collected routinely when a patient is undergoing in vitro fertilization (IVF) and are useful for studying granulosal lutein cells of the CL. Altering intracellular calcium in these cells through an ionophore, A23187, increased basal P4 production. However, at high concentrations a calcium chelator, BAPTA, decreased P4 from mural granulosal cells. Infertility is a problem that affects more than 6.1 million women and their partners across the United States. Causes of infertility range from female related tubal factors such as blockage, endometriosis, diminished ovarian reserve, to male related infertility due to abnormal sperm motility or morphology to unexplained infertility. Primary infertility types, age, BMI, and pregnancy outcome influenced ability of granulosal cells to increase $\mathrm{P} 4$ production when stimulated with human chorionic gonadotropin (hCG). AICAR decreased basal P4 production in these cells, which is similar to earlier observations in the mature bovine CL. Thus, AMPK appears to be a distal target in the pathway responsible for mediating the actions of $\mathrm{PGF}_{2} \alpha$. Directly activating AMPK could lead to better estrous cycle manipulation in the cow, or overcoming luteal insufficiency in women undergoing IVF. 


\section{Dedication}

"Here's to strong women, May we know them, May we be them, May we raise them." -Unknown

To my daughter, Charlotte, and to all the great women who have made me who I am. 


\section{Acknowledgements}

I would like to begin by thanking my advisor, Dr. Jorge Flores. His passion for science is both palpable and contagious. He has taught me to think outside the box whenever possible, attempted to improve my poor Spanish language skills, and reminded me that science should always be fun. Thank you for always supporting me as a scientist, and as an individual throughout this journey.

Thank you to my committee members for guiding me along this path to success, each in your own individual ways. Thank you to Dr. Clemmer for always inviting me to observe procedures at the CRM, and for being a great example of what a scientist and a mother looks like. Dr. Vernon thank you for all the knowledge you provided during seminars, and the great girl's photobomb from the Kentucky Research Symposium trip. It's classic. I would not have considered coming to WVU for a $\mathrm{PhD}$ if it weren't for Dr. Inskeep. Thank you for all you have done for the WVU reproductive physiology program, and thank you for not retiring prior to my decision to come here. I am also forever grateful for the appreciation of the historical perspective and your knowledge of the literature that you have passed on to me. Thank you Dr. Yao for always listening and assisting me when I had a problem in the lab. More importantly, thank you for teaching me that it's not always critical, and to believe in my project. I am also incredibly appreciative of the ways that Dr. Dailey has built my critical thinking and "interpretation" skills. Thank you for letting me make mistakes and being there as I worked through the solutions. Even when you knew I had made the mistake before I did.

I would not be where or who I am today without the love and unwavering support my family. Thank you to my parents and my brother, and all of the wonderful members 
of the Bowdridge bunch that have supported me from afar. You are the best people in the world, and I am so lucky to call you guys mine. Thank you to my friends who have stuck by me since middle school, and never really understood why I'm still in school. A special thank you to Kristina, who helped me name this dissertation, Phyllis my " $\mathrm{PhD}$ baby", and always asked how things were going. That meant more than I could ever express. I big thank you to Ida for walking me through my statistics and always being a smiling and encouraging face for me. Thank you all the graduate students both in animal science and biology. We are the only ones who truly know what we're going through at the time, and having that community is priceless.

I can never say thank you enough to my husband, Scott. We began this journey together three and a half years ago, and I wouldn't have gone through it with anyone else. Your support, wisdom, and love have been the driving force behind me continuing to move forward in this endeavor. You can't read this yet, but thank you to my daughter, Charlotte. I never knew what real dedication, perseverance, hard work, or love was until you joined our family. You are my life. I love you both so much. 


\section{Table of Contents}

The role of adenosine monophosphate activated kinase in luteal progesterone

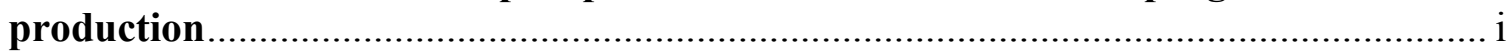

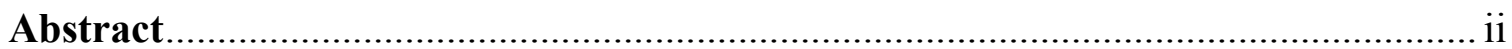

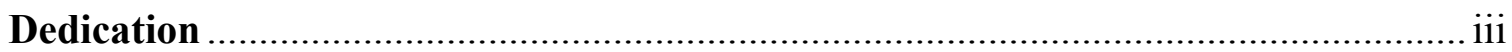

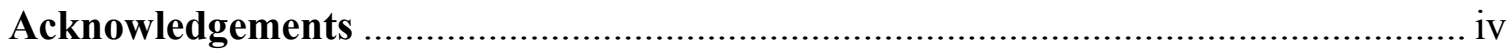

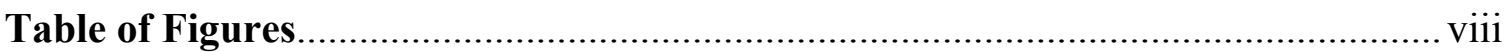

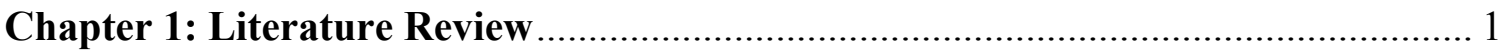

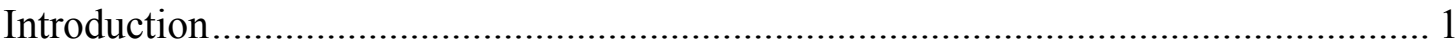

Development of the bovine corpus luteum ................................................................ 2

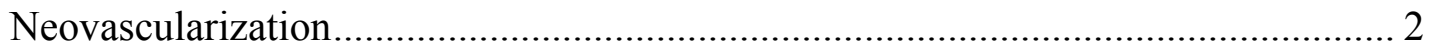

Small and large luteal cells ................................................................................. 4

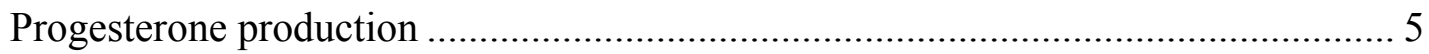

Lutienization of human mural granulosal cells....................................................... 6

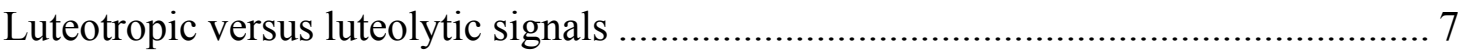

Luteotropic hormones ………………………………...................................... 7

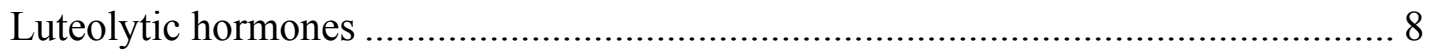

Signals for maintenance of the corpora lutea................................................................. 10

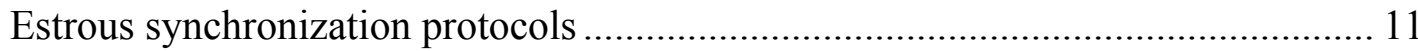

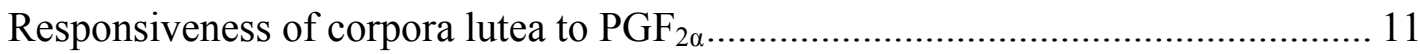

Normal versus induced corpora lutea ................................................................. 12

Structural and functional regression of corpus luteum ............................................. 12

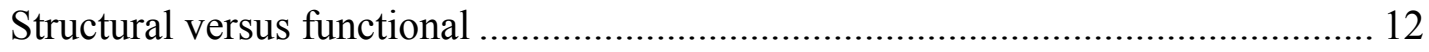

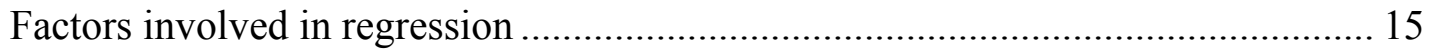

$\mathrm{PGF}_{2 \alpha}$ signal transduction pathway........................................................................ 21

Adenosine monophosphate activated kinase (AMPK) ………………………….... 21 


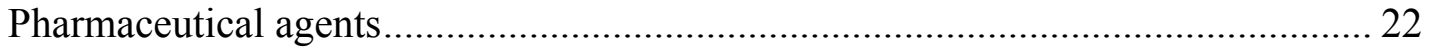

Model of activation of AMPK in the corpus luteum........................................... 25

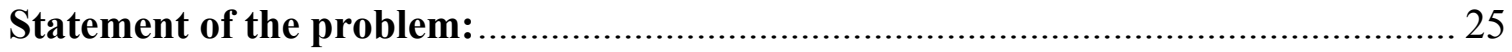

Chapter 2: Effects of prostaglandin $F 2$ alpha and adenosine monophosphate activated kinase on progesterone production in the bovine corpus luteum in vivo .. 28

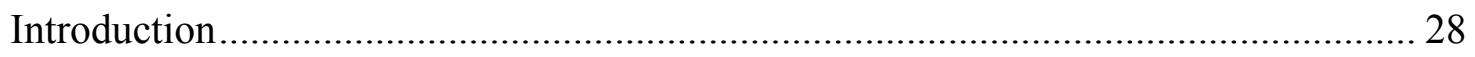

Materials and Methods....................................................................................... 31

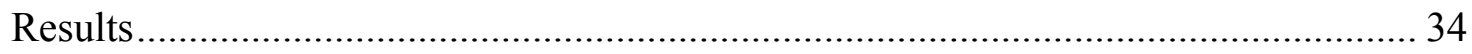

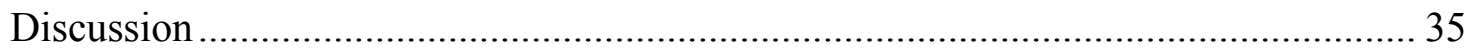

Chapter 3: Adenosine monophosphate activated protein kinase activation in vitro modulated progesterone secretion in mature but not developing bovine CL ......... 44

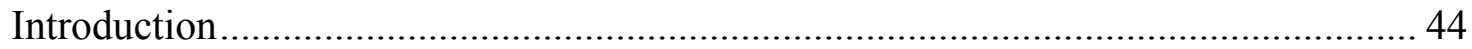

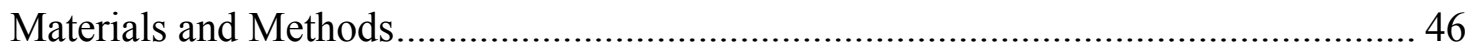

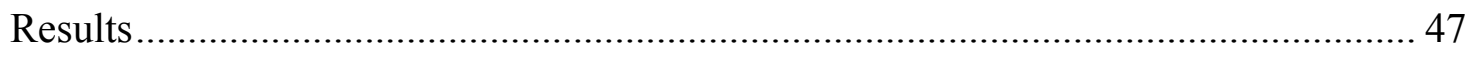

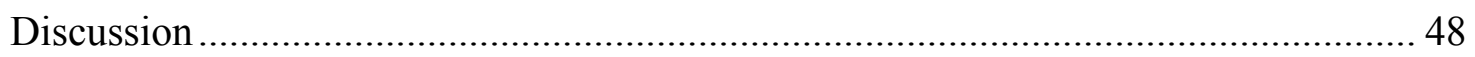

Chapter 4: Primary infertility affects progesterone production by luteinized human

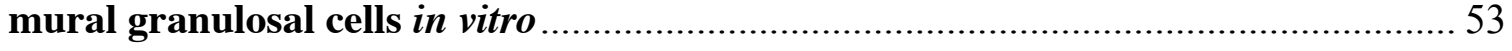

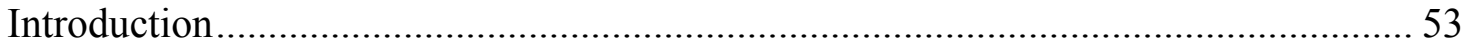

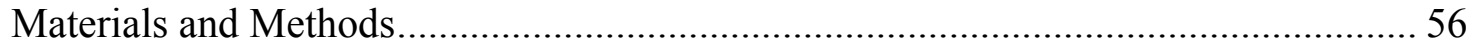

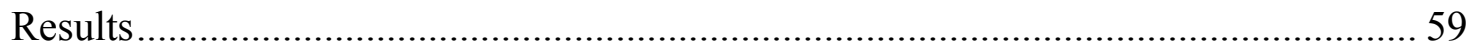

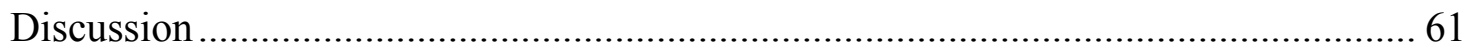

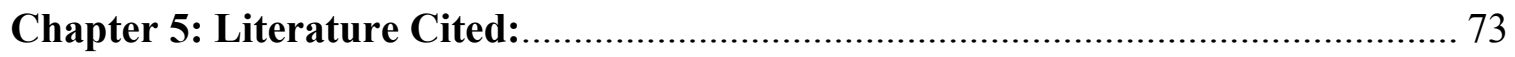




\section{Table of Figures}

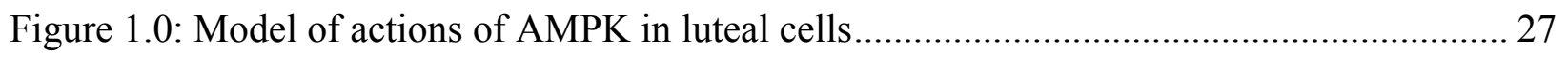

Figure 1.1: Bivariate fit of serum (A) and luteal (B) P4 (ng/ml) by time from $\mathrm{PGF}_{2 \alpha}(\mathrm{h})$. ........ 39

Figure 1.2: Semiquantitative analysis of the densitometric data derived from Western blots using protein samples isolated from mature bovine CLs 0,2 , and $4 \mathrm{~h}$ after $\mathrm{PGF}_{2 \alpha} \ldots \ldots \ldots \ldots \ldots \ldots . . . . .40$

Figure 1.3: Concentrations of serum progesterone after 15 or 30 (mg/kg of BW) IU of

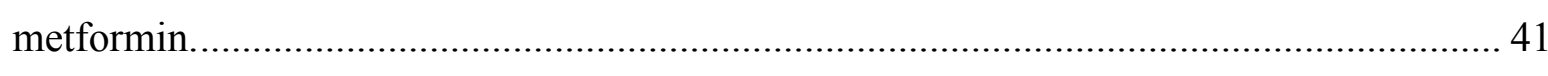

Figure 1.4: Concentrations of serum progesterone pooled across experiments........................... 42

Figure 1.5: Serum insulin concentrations one day prior to and during metformin treatment....... 43

Figure 2.1-Stimulatory effect of PGF2 $\alpha$ as blocked by DM in mature (d10) but not developing CL (d4). 50

Figure 2.2: Neither $\mathrm{PGF}_{2 \alpha}$ nor its activators, metformin and AICAR, had any significant effect on basal progesterone production in developing (D4) bovine CL...........................................51

Figure 2.3: At the greatest concentrations tested, both metformin and AICAR significantly decreased basal progesterone production in mature (D10) bovine CL. 52

Figure 3.1: Production of progesterone by granulosal cells from patients with male factor (A), endometriosis (B), diminished ovarian reserve (C), and tubal (D) primary infertility......... 65

Figure 3.2: Production of progesterone in mural granulosal cells as affected by age. .................. 66

Figure 3.3: Production of progesterone in mural granulosal cells as affected by BMI............... 67

Figure 3.4: Production of progesterone in mural granulosal cells as affected by pregnancy status

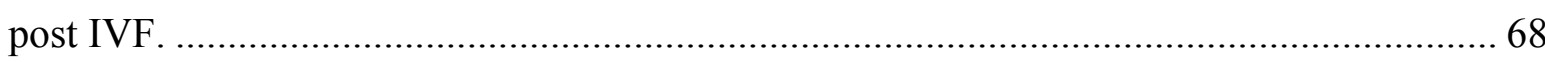

Figure 3.5: The AMPK activator, AICAR, inhibited P4 production by human luteinized mural granulosal cells.

Figure 3.6: Production of $\mathrm{P} 4$ as stimulated by $\mathrm{PGF}_{2 \alpha}$ in mural granulosal cells but not cumulus granulosal cells.

Figure 3.7: Biphasic effect of BAPTA on production of P4 in luteinized mural granulosal cells 71 Figure 3.8: Increases in intracellular $\mathrm{Ca}^{+2}$ increased productin of $\mathrm{P} 4$ in mural granulosal cells. 


\section{Chapter 1: Literature Review}

\section{Introduction}

Follicles, composed of the oocyte, granulosal and thecal cells, are the functional unit of the ovary. The somatic cells in the outermost vascular portion of the follicle include thecal and myoepithelial cells. Myoepithelial cells aid in rupture of the follicle during ovulation by increasing intrafollicular pressure through contraction. At least two populations of thecal cells are recognized: theca interna and theca externa. The theca interna expresses luteinizing hormone (LH) receptor and produces androstenedione, but does not contain aromatase, the enzyme needed for conversion of androstendione to estrogen, which is expressed in granulosal cells (Hseuh et al., 1984). The avascular component of the follicle is delimited by a basement membrane upon which the other somatic cells of the follicle, the granulosal epithelial layer and the germ cell reside. Two populations of granulosal cells have been identified: mural and cumulus granulosal cells. Both populations of cells are organized as a stratified epithelium with the basal layer of mural cells contacting the basement membrane adjacent to the thecal cells and the cumulus cells surrounding the oocyte (Buccione et al., 1990). The 2-cell, 2-gonadotropin theory was first suggested 50 years ago (Short, 1961). The theory is essential in understanding the role that these two types of granulosal cells play in estrogen secretion from the growing follicle (Liu and Hsueh, 1986). In most mammalian species, formation of a follicular antrum, a fluid filled form of extracellular matrix (ECM; Rogers and Rogers, 2010), divides these two populations of granulosal cells. Presumably, the antrum is formed by an osmotic gradient that draws fluid from the vasculature that is adjacent to the thecal cell population (Rogers and Rogers, 2010). Granulosal cells produce both hyaluronan and versican, and these two molecules contribute to cumulus cell expansion (Rogers and Rogers, 2010). After antrum formation, mural granulosal 
cells express both FSH and LH receptor as well as 3 $\beta$-HSD and P450 SCC (Zoller and Weisz, 1979) the expression of these two enzymes is more a luteal feature in these cells. Cumulus granulosal cells remain with the oocyte after ovulation and respond to the ovulatory LH surge by assembling another specialized ECM by a process known as cumulus expansion (Russell and Salustri, 2006). This unique set of somatic cells possess an epithelial phenotype and are tightly connected to one another via intercellular processes, known as gap junctions, which allow for passage of small molecules that regulate signaling and metabolism by the oocyte (Russell and Salustri, 2006). This subset of granulosal cells has a gene expression profile that is specific for cumulus cell expansion, which distinguishes them from mural granulosal cells, which do not undergo expansion. Once ovulation has occurred, mural granulosal cells lose their ability to proliferate, undergo epithelial-mesenchyme transition and differentiate into the large luteal cells (LLC) of the corpus luteum (CL), which secrete high concentrations of basal progesterone (Chaffkin et al., 1992). Theca cells become small luteal cells (SLC) once luteinization has occurred. In the primate, the granulosal and thecal cells remain as two distinct populations and are separated by the remnants of the follicular basement membrane (Guraya, 1971). In contrast, the basement membrane separating these two cell populations is degraded, and thecal cells invade the granulosa to form a heterogeneous mixture of cells in the CL of nonprimate species (Niswender, 2000).

\section{Development of the bovine corpus luteum}

\section{Neovascularization}

The CL is a transient endocrine organ that begins to form immediately after ovulation and requires extensive neovascularization to ensure both structural and functional development. During the first eight to ten days of growth, the CL doubles in size and cell number every $60-70$ 
hours (Reynolds et al., 1994). This rate of growth is comparable to the fastest growing tumors, yet, unlike tumors, cell proliferation in the CL is self-limiting and tightly regulated (Reynolds et al., 1994). Ovulated follicular tissues of approximately $40 \mathrm{mg}$ grow to 600-700 $\mathrm{mg}$ of CL tissue within a few days (Reynolds, 2000). This growth can be attributed to hyperplasia of SLC, fibroblasts, and endothelial cells, as well as hypertrophy LLCs without hyperplasia in the ovine CL (Farin et al., 1986). However, in vitro both hypertrophy and hyperplasia occur in bovine luteal steroidogenic cells as measured by cell cycle (cyclin D2 and E1) and cell proliferation (Ki-67) genes (Yoshioka et al., 2013). To support such extensive cell growth, angiogenesis occurs rapidly and reaches a maximum 2 to 3 days after ovulation (Reynolds, 2000). This change is reflected by the fact that approximately $50-85 \%$ of the luteal cell proliferation occurs in the microvasculature unit, and endothelial cells and pericytes make up over half of the cell population in the mature CL (Reynolds et al., 1994). Increased vascularization enables the CL to receive more blood flow per unit of tissue than any other mature organ in the body (Reynolds, 2000). Most membranes of luteal cells are either adjacent to capillaries or adjacent to the interstitial space that is in close proximity to capillaries (Dharmarajan et al., 1985). Inadequate or subfunctional luteal development is known to occur in cattle (Redmer \& Reynolds, 1996) and in humans (Reynolds et al., 2000) and is associated with reduced vascularization in both cases.

Several angiogenic factors contribute to the vascularization of the bovine CL. Two key mediators in neovascularization are fibroblast growth factor 2 (FGF2) and vascular endothelial growth factor (VEGF) A (Robinson et al., 2009). Both VEGF and its receptors VEGFR1 and VEGFR2 mRNA are expressed in the bovine CL and endothelial cells (Berisha et al., 2000). Additionally, VEGF is a mitogen for endothelial cells, and its expression is induced by the preovulatory LH surge (Garrido et. al, 1993). In the cow, FGF2 protein synthesis occurs in 
endothelial cells and pericytes of the thecal layer occur prior to the LH surge and in the luteinizing granulosa mainly after ovulation (Berisha et al., 2006). After a few days FGF2 was absent from all steroidogenic cells but reappeared in endothelial cells (Berisha et al., 2006). Both endothelial cells (Robinson et al., 2008) and pericytes (Robinson et al., 2007) are targets for multiple angiogenic factors. Pericytes appear to play a dual role in neovascularization. First they act as a guide for the outgrowth of endothelial cells, and secondly they help stabilize newly formed vessels (Robinson et al., 2009). Changes in mRNA and protein expression in FGF2 that occur after the LH surge imply that FGF2 is crucial for the follicle-luteal transition in cattle (Robinson et al., 2007). The LH surge had no effect on VEGF concentrations, so VEGF is thought to play a constitutive, but essential, role in the development of luteal vasculature (Robinson et al., 2007). Both factors and their receptors are expressed at higher concentrations in the developing bovine $\mathrm{CL}$ and decrease significantly in the maintenance to regressing $\mathrm{CL}$ (Schams et al., 1994; Berisha et al., 2000).

\section{Small and large luteal cells}

Two morphologically distinct steroidogenic cells types comprise CL of cattle, sheep and many other mammalian species (Niswender and Nett, 1994). Small luteal cells $(18-20 \mu \mathrm{m})$ are derived from the thecal cells of the follicle, contain receptor for luteinizing hormone ( $\mathrm{LH})$, respond to LH by producing cAMP and increasing secretion of progesterone, and usually contain multiple lipid droplets (Niswender, 2002). The number of SLC increased four-fold from day 4 to day 8 in the estrous cycle of the ewe, but these cells maintained a constant volume (Farin et al., 1986). Large luteal cells $(25-40 \mu \mathrm{m})$ originate from granulosal cells, secrete high basal concentrations of progesterone, and have receptors for both $\mathrm{LH}$ and $\mathrm{PGF}_{2} \alpha$ (Niswender, 2002). Numbers of LLC did not change throughout the estrous cycle of the 
ewe but volume and diameter increased until day 16 of the cycle (Farin et al., 1986). Basal secretion of progesterone differs between these two luteal cell types with LLC producing 2-40 times more progesterone than SLC (Niswender et al., 2000). Both LLC and SLC differ in their response when stimulated with hormones and/or intracellular mediators. Physiological concentrations of LH increased secretion of progesterone from bovine SLC but not LLC in vitro (Alila et al., 1998). Steroidogenic cells in the CL synthesize large amounts of progesterone. Increased synthesis of progesterone occurs as the CL develops and is maintained if a pregnancy is established, or is abolished due to CL regression.

\section{Progesterone production}

All steroids, including progesterone, are derived from cholesterol, which can come from the plasma membrane, cellular stores (lipid droplets), lipoproteins (low density lipoproteins [LDL] and high density lipoproteins [HDL]), and de novo synthesis (Hu et al., 2010). Each LDL particle contains approximately 2500 cholesterol molecules, which makes this pathway very efficient for progesterone production. Uptake of LDL by luteal cells occurs by receptormediated endocytosis (Hu et al., 2010). During this process, LDL binds to its plasma membrane (PM) bound receptor, which then translocates to specialized regions of the PM called coated pits to invaginate and pinch off to form clathrin-coated vesicles (Hu et al., 2010). These vesicles rapidly fuse with lysosomes where the protein of the LDL is hydrolyzed to amino acids and cholesteryl esters are hydrolyzed by a lysosomal acid lipase (Brown and Goldstein, 1979). The LDL-receptor complex rapidly dissociates with the full intact LDL-receptor being sorted and returned to the PM. The resulting cholesterol from the LDL particle can be released and transported to the mitochondria for steroid hormone synthesis (Hu et al., 2010) or undergo esterification by A:cholesterol acyltransferase 1 (ACAT1). Additionally, ACAT1 is responsible 
for esterification of de novo synthesized cholesterol. Cholesterol esters are stored in lipid droplets, which have been shown to be hormonally regulated in steroidogenic cells of the adrenal, ovary and testis (Behrman and Greep, 1972; Hu et al., 2010).

The HDL is taken up by the cell by binding to the plasma membrane-bound HDL binding protein (Lestavel and Fruchart, 1994), and cholesterol is mobilized into the cell by an undefined mechanism. Free cholesterol is transported to the mitochondria along the cytoskeletal network and by sterol carrier proteins where it is then transported from the outer to inner mitochondrial membrane by steroidogenic acute regulatory protein (StAR) (Niswender, 2002). Cholesterol is converted to pregnenolone by an inner mitochondrial enzyme, cytochrome P450 side chain cleavage (P450scc). Pregnenolone travels out of the mitochondria and is converted to progesterone by the smooth endoplasmic reticulum enzyme $3 \beta$-hydroxysteroid dehydrogenase (3ß-HSD) (Niswender, 2002). Additionally, peripheral-type benzodiazepine receptors (PBR) may play a role in cholesterol transport as it is moved from the outer to inner mitochondrial membranes (Niswender, 2002). Targeted deletion of the PBR from Leydig cells drastically reduced steroid secretion, and reintroduction of PBR allowed steroid secretion to be restored (Papadopoulos et al., 1997). Additionally, phosphorylation of PBR by protein kinase A (PKA) enhanced cholesterol transport (Papadopoulos et al., 1997). It is possible that PBR works as a cholesterol channel.

\section{Luteinization of human mural granulosal cells}

During follicular development granulosal cells primarily secrete estrogen $\left(E_{2}\right)$, but as ovulation approaches they begin to produce progesterone $\left(\mathrm{P}_{4}\right)$. During the preovulatory period $\mathrm{E}_{2}$ secretion is drastically reduced, and granulosal cells begin to synthesize $\mathrm{P}_{4}$ (McNatty et al., 1979). Additionally, these cells undergo loss of aromatase and mitotic activity (Robertson and 
Baker, 1969; Friedrich et al., 1975). Interestingly, $\mathrm{P}_{4}$ receptors (PGR) cannot be detected with immunohistochemical analysis in human granulosal cells at any follicular stage but are detected readily in human luteal tissue (Suzuki et al., 1994). This finding supports the hypothesis that LH induces PGR expression (Hild-Petito et al., 1988).

Human granulosal cells recovered during oocyte retrieval in patients undergoing in vitro fertilization have been shown to luteinize in culture and, therefore, have been used as a model to study granulosal lutein cells of the CL (Stewart and Vandevoort, 1997). This model has several advantages: no collagenases or other proteolytic enzymes that may influence hormone secretions are needed for cell isolation; unlike ovarian cell line cultures, primary granulosal cell cultures retain their ability to produce and respond to steroid hormones; and serum-free media can be used to examine circulating hormones or serum-derived factors (Hsueh et al., 1984). This model has limitations: absence of vascularization and the influence of angiogenic factors; inability of other follicular cell types such as theca interna or oocyte-cumulus cells to influence granulosal cell differentiation (Hsueh et al., 1984); and representative of only one stage of development of the CL (which has not been clearly defined) and do not take into account the heterogeneity of a granulosal cell population or the fertility status of the patient from which they were isolated.

\section{Luteotropic versus luteolytic signals}

\section{Luteotropic hormones}

Luteotropic hormones support the growth and/or function of the CL. Luteinizing hormone (LH), growth hormone (GH), prolactin, insulin-like growth factor 1 (IGF-1), prostaglandin $(\mathrm{PG}) \mathrm{E} 2\left(\mathrm{PGE}_{2}\right)$ and prostacyclin $\left(\mathrm{PGI}_{2}\right)$ are all luteotropic hormones. In order to increase P4 LH acts on the SLC of most species and the LLC in pregnant and pseudopregnant rats as well as nonhuman primates (Hild-Petito et al., 1989; Niswender et al., 2000). Most 
luteotropic hormones work by initiating the same intracellular mediator cascade. For example in bovine luteal tissue or cells, LH binds to its G-protein-coupled receptor in SLC and activates adenylate cyclase, which increases concentrations of cyclic adenosine monophosphate (cAMP) and activates PKA (Hoyer et al., 1984). Increase in P4 is achieved through increased transport of cholesterol to the P-450 SCC enzyme complex to the mitochondria (Wiltbank et al., 1993). The LLC also express LH receptor but secrete more basal P4 than SLC, so an increase in response to LH may be due to constitutively expressed PKA (Hoyer et al., 1984).

\section{Luteolytic hormones}

Luteolytic hormones promote luteal regression. In many species, including cattle, $\mathrm{PGF}_{2} \alpha$ is the primary uterine factor responsible for functional and structural luteolysis (McCracken, 1971). Additionally, oxytocin and luteal $\mathrm{PGF}_{2 \alpha}$ play roles in luteolysis. Increases in protein kinase $\mathrm{C}(\mathrm{PKC})$ enzyme activity and intracellular calcium mediate the anti-steroidogenic effects of $\mathrm{PGF}_{2} \alpha$ (Niswender et al., 2000). In fact, $\mathrm{PGF}_{2} \alpha$-induced accumulation of extracellular calcium in the cytosolic compartment enhances PKC enzyme activity (Niswender, 2000).

Metabolism and actions of intraluteal PGs, including but not limited to $\mathrm{PGF}_{2 \alpha}$, affect the lifespan of the CL. Actions of luteal-derived $\mathrm{PGF}_{2 \alpha}$ are likely mediated by the G-protein coupled plasma membrane receptor, FP, that uterine $\mathrm{PGF}_{2} \alpha$ acts on (Wiltbank and Ottobre, 2003). Expression of FP receptor mRNA is present at 100-fold greater concentrations in the CL than in any other tissue, EP3 receptor is also expressed (Anderson et al., 2001). Koybayashi et al. (2001) found that developing bovine CL (day 3) produce more $\mathrm{PGF}_{2 \alpha}$ than mid phase CL (days 4-6). In agreement with those results, luteal concentrations of cyclooxygenase-2 (COX-2) mRNA were greater in the developing than mature to regressing CL. Additionally, $\mathrm{PGF}_{2} \alpha$ increased the availability of arachidonic acid (AA) and COX-2 activity, both essential for PG 
production in the CL (Niswender et al., 2000). This evidence supports the ability of $\mathrm{PGF}_{2} \alpha$ to regulate its own production in the CL. However, a temporal relationship exists in the ratio of luteotropic $\left(\mathrm{PGI}_{2}\right)$ and luteolytic $\left(\mathrm{PGF}_{2 \alpha}\right)$ PGs throughout the estrous cycle (Milvae and Hansel, 1983). Luteal PGs are stimulated by cytokines such as INF $\gamma$ (Fairchild and Pate, 1991) and TNF $\alpha$ (Benyo and Pate, 1992) but suppressed by high intraluteal concentrations of progesterone (Pate, 1988). Although uterine-derived $\mathrm{PGF}_{2} \alpha$ is the main luteolytic factor in ruminants, other PGs appear to play a role in determining the lifespan of the CL.

Luteal regression is not mediated by uterine $\mathrm{PGF}_{2} \alpha$ in primates (Beling, 1970). Infusion of $\mathrm{PGF}_{2} \alpha$ directly into the $\mathrm{CL}$ reduced $\mathrm{P} 4$ and caused premature menses in monkeys (Auletta et al., 1984). It has been suggested that luteal-derived $\mathrm{PGF}_{2} \alpha$ acts in a paracrine and/or autocrine manner to induce luteal regression (Auletta and Flint, 1988). Despite this evidence, the source and actions of $\mathrm{PGF}_{2} \alpha$ in the primate still remain controversial.

Oxytocin is secreted mainly by the posterior pituitary during and after parturition and lactation in order for milk letdown to occur, but also it is an important factor during luteal regression. Flint and Sheldrick (1982) showed that a rapid increase of ovarian oxytocin was elicited within five minutes of administering a $\mathrm{PGF}_{2 \alpha}$ analogue (Estrumate ${ }^{\circledR}, 125 \mu \mathrm{g}$ i.m.). In part due to this finding, McCracken et al. in 1996 suggested that the initiating factor for luteolysis is stimulation of posterior pituitary oxytocin by $\mathrm{E}_{2}$ or the removal of $\mathrm{P} 4$ (McCracken et al., 1996), which in turn stimulate secretion of uterine $\mathrm{PGF}_{2 \alpha}$ (Fairclough et al., 1980). This cascade leads to a positive feedback loop that causes the release of luteal oxytocin as well as luteal and more uterine $\mathrm{PGF}_{2 \alpha}$ (Silvia et al., 1991) leading to luteal regression. One explanation for the time between pulses of naturally occurring uterine $\mathrm{PGF}_{2 \alpha}$ is refractoriness of the uterus to oxytocin. However, depletion of oxytocin or its receptors in the bovine CL did not delay 
luteolysis (Kotwica and Skarzynksi, 1999), implying that it is not critical for luteal regression. The role of oxytocin in luteal regression remain controversial.

\section{Signals for maintenance of corpora lutea}

During gestation, maternal recognition of pregnancy must occur so that P4 synthesis and secretion continue uninterrupted. Considerable variation exists among species, but, in general, the conceptus secretes factors that are anti-luteolytic $($ anti-PGF $2 \alpha)$ or luteotropic (Roberts et al., 1996) to maintain the CL and P4 secretion. In the case of the human, [human] chorionic gonadotropin (hCG) is secreted by the trophoblastic cells of the implanting embryo (Hearn et al., 1991) and binds to the LH receptors in the CL to increase P4 secretion as well to protect the CL from $\mathrm{PGF}_{2 \alpha}$ (Patton and Stouffer, 1991). In contrast, in the cow, secretion of the protein interferon tau (IF $\tau)$ by the trophectoderm of the elongating blastocyst has been postulated to suppress the pulsatile release of $\mathrm{PGF}_{2 \alpha}$ from the uterus (Roberts et al., 1996).

During a non-fertile luteal phase, luteotropic signals allow the CL to increase in size and ability to secrete P4 (Niswender et al., 2000). However, if a pregnancy is not established, the CL must regress in order for another follicle to grow, ovulate, and a new cycle begin. As mentioned earlier, uterine $\mathrm{PGF}_{2 \alpha}$ is the luteolytic signal in ruminants. In the cow, both large and small luteal cells are capable of responding to $\mathrm{PGF}_{2} \alpha$ with an increase in intracellular $\mathrm{Ca}^{+2}$ (Choudhary et al., 2004). The binding of $\mathrm{PGF}_{2 \alpha}$ to its receptor in these luteal cells activates two pathways that affect steroidogenesis in the CL. The first is activation of PKC, which directly inhibits progesterone production (Niswender, 2002). Additionally, increases in free intracellular $\mathrm{Ca}^{+2}$ lead to apoptosis and cell death (Wiltbank et al., 1989). In primates, the role of $\mathrm{PGF}_{2 \alpha}$ is controversial but may play a role when it is of ovarian origin. Due to these actions $\mathrm{PGF}_{2} \alpha$ is utilized extensively in livestock species to synchronize estrus. However, the bovine CL is 
resistant to luteal regression by exogenous $\mathrm{PGF}_{2} \alpha$ before day 5 (D 5) of the estrous cycle.

\section{Estrous synchronization protocols}

The discovery of $\mathrm{PGF}_{2 \alpha}$ as the luteolysin in ruminant species led to an explosion of synchronization protocols specifically in dairy cattle (Pursley et al. 1995). Synchronizing estrus with exogenous $\mathrm{PGF}_{2 \alpha}$ allowed for more easily detecting estrus in large herds as well as more efficient artificial insemination (AI) programs (Stevenson and Pursley, 1994). Originally, PGF $_{2 \alpha}$ was given twice, 11 days apart (Lucy et al., 1986). However, it was found that while $60 \%$ of cows responded to the first $\mathrm{PGF}_{2 \alpha}$ injection by $\mathrm{CL}$ regression only $72 \%$ responded to the second injection when all animals should have had CL older than 5 days (Lucy et al., 1986). Due to variabilty in time to estrus and low conception rates for fixed time AI, GnRH was incorporated into estrous synchronization protocols in order to initiate a new follicular wave with a dominant follicle prior to $\mathrm{PGF}_{2 \alpha}$ and to more tightly synchronize ovulation 24 hours before breeding (Pursley et al., 1995).

\section{Responsiveness of corpora lutea to $\mathrm{PGF}_{2 \alpha}$}

The ability of the CL to respond to the luteolytic actions of $\mathrm{PGF}_{2 \alpha}$ increases with maturation in cattle. The developing CL (days 1-5) will not regress if a single administration of $\mathrm{PGF}_{2 \alpha}$ is given, but in the mature CL (days 6-15), the same dose of exogenous $\mathrm{PGF}_{2 \alpha}$, will induce regression, and the cow will come into estrus within 48-72 hours (Rowson, Tervit and Brand, 1972; Inskeep, 1973). However, differences in response to $\mathrm{PGF}_{2 \alpha}$ have been noted across timespans during the mature phase of the CL. In 1984, Tanabe and Hann administered a single injection of $\mathrm{PGF}_{2 \alpha}$ on days 7,11 , or 15 of the estrous cycle in heifers and found that the percentage of heifers exhibiting synchronized estrus at 80 hours afer $\mathrm{PGF}_{2 \alpha}$ tended to increase with stage of estrous cycle (day 7-86\%, day $11-90 \%$, and day $15-98 \%$ ). This area of research has 
been under intensive investigation for many years, but the mechanism for the developmental difference is still not understood. However, lack of receptors (Wiltbank, 1995; Wright et al., 2014) or the ability of $\mathrm{PGF}_{2 \alpha}$ to produce physiological responses (Tsai and Wiltbank, 1998; Sen et al., 2005) do not explain this difference in the developing CL.

\section{Normal versus induced corpora lutea}

There is evidence that a CL formed after a spontaneous ovulation is characteristically different than one formed when the previous CL is regressed by pharmaceutical methods. In a study by Keisler and Keisler in 1989, CL that were induced in the absence of an existing CL were short-lived whereas CL that were induced during the luteal phase of the estrous cycle did not affect lifespan of spontaneous CL. However, in Brahman cattle, no difference in CL weight, progesterone content, or number of LH receptors were found between spontaneous and induced CL (Hansen et al., 1987). .

In multiple species, $\mathrm{PGF}_{2 \alpha}$ elicits both inhibitory and stimulatory responses to $\mathrm{P} 4$ in luteal cells in vitro. Most investigators used a non-physiological dose of $\mathrm{PGF}_{2 \alpha}$ when treating luteal cells in vitro. The fact that $\mathrm{PGF}_{2 \alpha}$ at high concentration is able to activate the $\mathrm{PGE}_{2}$ receptor (Rao, 1974) could, in part, explain increases in progesterone production. Additionally, the entire population of cells that would normally be present in addition to luteinized granulosal cells are not present in all in vitro experiments. The inhibitory action of $\mathrm{PGF}_{2 \alpha}$ on human luteinized granulosal cells may be enhanced by the presence of endothelial and/or immune cell types (Liptak et al., 2005).

\section{Structural and functional regression of corpora lutea}

\section{Structural versus functional}

Through decades of luteal physiology research, luteal regression has come to be defined 
as either structural or functional (Bowen-Shauver and Telleria, 2003). Functional regression is defined as the cessation of $\mathrm{P} 4$ production, whereas structural regression refers to a decrease in weight and size of the CL (Goyeneche et al., 2002) and then disappearance of the structure on the ovary (Bowen-Shauver and Telleria, 2003). Progress has been made in separating these two events in vivo, as well as distinguishing between the two in the literature. However, it is important that these terms are defined in the context of both the species and the reproductive stage being studied (Davis and Rueda, 2002).

Signs of functional regression occur prior to structural regression; presumably the loss of P4 production by the CL ultimately leads to its morphological changes and ultimately structural regression. Initial changes seen in serum P4 are not due to loss of steroidogenic luteal cells, because numbers of large luteal cells do not decrease until after a dramatic decrease in P4 (Braden et al., 1988). Therefore, a decrease in blood flow to the CL and decreased steroidogenic capacity of luteal cells is one possible explanation for this decrease in P4. However, a decrease in P4 prior to a decrease in luteal blood flow has been seen in rodents (Behrman et al., 1979) rabbits (Keyes et al., 1983) and domestic species (Ginther et al., 2007). Studying spontaneous luteolysis has proven to be difficult because timing, duration and number of pulses of uterine $\mathrm{PGF}_{2 \alpha}$ differ among individuals. Decreased mRNA and protein of enzymes (3ß-HSD, StAR, etc.) that contribute to luteal regression also are expressed at inconsistent times, which makes finding significant changes within a group of animals difficult due to the variation. Due to this fact, researchers have focused on subsequent changes in these key factors after administration of $\mathrm{PGF}_{2 \alpha}$.

Structural regression occurs due to a series of physiological changes that result in distinct morphological changes in the CL. One such event that contributes greatly to the demise of the 
CL is apoptosis, which is promoted by $\mathrm{PGF}_{2 \alpha}$ (Sawyer, et al., 1990). Apoptosis, also known as programmed cell death, is defined as an active, energy dependent process by which nonessential populations of cells are removed by other cells from tissue (Kerr et al., 1972), a mechanism that allows for control of cell numbers and tissue size. Apoptosis in endocrine tissues commonly occurs after the tropic hormone is removed or a negative stimulus is activated. Cells shrink, and fragments of both nuclear and cytoplasmic origin appear (Kerr et al., 1972). Apoptosis is categorized into the intrinsic and extrinsic signaling cascade. The intrinsic pathway is activated by apoptotic signals that originate within the cell in response to insults such as drugs, radiation, or growth factor withdrawal. As a result, a change in mitochondrial permeability occurs through modifications in the ratio of pro- to anti-apoptotic Bcl-2 family members (Adams and Cory, 1998). Alternatively, the extrinsic pathway is activated by extracellular signals, such as Fas, or tumor necrosis factor alpha (TNF- $\alpha$ ), that bind with cell surface receptors to inititate cell death (Nagata, 1997). Caspases, a family of intracelluar proteases, are activated by both pathways and cleave multiple cellular components that contribute to the typical morphological appearance in apoptotic cells (Martin and Green, 1995). These fragments, known as apoptotic bodies, are targets for macrophages and other immune cells.

Specifically, the proportion of steroidogenic luteal cells in the CL of ewes decreased within 24 hours of $\mathrm{PGF}_{2 \alpha}$ treatment during the maintenance phase (Braden et al., 1998). Both the number and size of LLCs decreased, and this was followed by a decrease in the number of SLC (Braden et al., 1998). Morphological changes in the steroidogenic cell population of the CL do not become visible until 24-36 hours post $\mathrm{PGF}_{2 \alpha}$ (Sawyer et al., 1990), yet their ability to produce $\mathrm{P} 4$ has already been compromised. This indicates that the structural changes in the $\mathrm{CL}$ are a consequence of reduced $\mathrm{P} 4$ production and not vice versa. However, it could indicate that 
functional regression is regulated by a different mechanism than apoptosis, such as autophagy.

Indeed, autophagy has been shown to play a role in structural regression in human and rats. Autophagy is an intracellular bulk degradation system in which portions of cytoplasm are enveloped into autophagosomes that then undergo maturation and fusion with lysosomes for degradation (Klionsky and Emr, 2000). The apperance of cytoplasmic vacuoles, prominent lysosomes, and the accumulation of lipfucsin pigment without any changes in nuclear morphology in the regressing primate CL strongly indicate that autophagy induces or at least plays a part in the death of steroidogenic luteal cells (Morales et al., 2000). Additionally, autophagy has been shown to play a role in luteal regression in the rat by accumulation of autophagosomes, which then induce apoptotic cell death in luteal cells (Choi et al., 2011). Autophagy is promoted by adenosine monophosphate activated protein kinase (AMPK; Kim et al., 2011). The role autophagy plays in bovine luteal regression has yet to be examined.

However, AMPK reduced P4 production in murine, galline and bovine granulosal cells (Tosca et al., 2005; Tosca et al., 2006; Tosca et al., 2007), which will be discussed at greater length later in this review. The link between AMPK and autophagy induction in bovine luteal tissue has not been determined.

\section{Factors involved in regression}

\section{Luteal blood flow}

Changes in luteal blood flow have been proposed to be one of the main mechanisms by which $\mathrm{PGF}_{2 \alpha}$ exerts its luteolytic actions (Nett et al., 1976; Knickerbocker, 1988). In ewes, $\mathrm{PGF}_{2 \alpha}$ reduces blood flow to the CL concomitantly with decreased secretion of P4 (Nett et al., 1976). Color Doppler ultrasound is a non-invasive and useful technique to examine blood flow within the CL during its development (Acosta et al., 2003) and demise (Acosta et al., 2002). On 
days 16-18 of the estrous cycle in cattle, during spontaneous luteolysis, an increase in blood flow surrounding the CL was observed followed by decreased plasma P4 the next day (Shirasuna et al., 2004; Miyamoto et al., 2005). An acute increase in blood flow (0.5 to 2 hours) also was seen during $\mathrm{PGF}_{2 \alpha}$-induced luteolysis in mature (day 10) but not developing (day 4) bovine CL (Acosta et al., 2002). This increase was followed by a decrease in plasma P4 at 0.5 hours and blood flow at 8 hours (Acosta et al., 2002). Expression of vasoactive factors must increase in order to mediate this increase in blood flow. One such factor, nitric oxide (NO), a vasodilator, was proposed to be stimulated by $\mathrm{PGF}_{2 \alpha}$ (Yamamoto et al., 2004). Indeed, in a different tissue, it has been postulated that uterine $\mathrm{PGF}_{2 \alpha}$ induces $\mathrm{NO}$ production from large arterioles to acutely increase luteal blood flow and initiate luteolysis (Miyamoto et al., 2005). However, other investigators were unable to find an increase in luteal blood flow at the initiation of luteolysis (Ginther et al., 2007). In fact, a decrease in blood flow was not observed until the day after P4 decreased (Ginther et al., 2007).

\section{Protective effect of progesterone}

Luteal P4 has been shown to exert protective effects on CL as a luteotropin by increasing the number of LH receptors in the early CL (Rothchild, 1981) and through anti-apoptotic activity (Rueda et al., 1997). Direct supplementation of P4 to dispersed mature bovine luteal cells initiated a decrease in prostacyclin and $\mathrm{PGF}_{2 \alpha}$ synthesis (Pate, 1988), which indicates that $\mathrm{P} 4$ action could also be anti-luteolytic. This evidence shows that P4 can protect the lifespan of the CL by blocking a decrease $\mathrm{P} 4$ production, reducing cell death, and preventing luteolytic factors such as $\mathrm{PGF}_{2 \alpha}$ from regressing the CL. The P4 receptor, PR, is present in LLC and some SLC, but not endothelial cells (Rueda et al., 2000), and it was further delineated that two isoforms of PR, PR-A and PR-B, are expressed in the bovine CL (Kotwica et al., 2004). Protein synthesis of 
these classical genomic receptors changes throughout the estrous cycle and pregnancy with the highest concentrations found at days 5-10 of the cycle and no expression in the regressing CL (Kotwica et al., 2004). Actions of P4 could be exerted through the genomic receptor; however, these effects could be mediated by the glucocorticoid receptor (Sugino et al., 1997) or through the non-genomic plasma membrane bound PR (Peluso, 1997).

\section{Pulsatile uterine $\mathrm{PGF}_{2 \alpha}$}

Prostaglandin F2 $\alpha$ is released in a series of pulses from the non-pregnant uterus in order to regress the bovine CL (Niswender, 2002). Uterine release of $\mathrm{PGF}_{2} \alpha$ is transferred to the ovary through the utero-ovarian vein via a counter current exchange mechanism (McCracken et al., 1972). This helps ensure that $\mathrm{PGF}_{2} \alpha$ is not enzymatically inactivated in the lungs by $\mathrm{PG}$ dehydrogenase (PGHD) (Piper et al., 1970). Transport of PGs through plasma membranes is poorly understand, but prostaglandin transporter (PGT) mediates the efflux and influx of PGF $2 \alpha$ (Schuster, 1998). Recently Lee et al. (2013) showed PGT protein was required for pulsatile release of $\mathrm{PGF}_{2 \alpha}$ from the endometrium and to maintain a functional CL in sheep. Number and frequency of pulses vary considerably during natural ruminant luteal regression but approximately 5 distinct pulses, each around 4-hour duration over a period of approximately 30 hours, are required for luteal regression in heifers (Mann and Lamming, 2006). In cattle, P4 decreases during the ascending portion of a naturally occurring uterine PGF pulse but increases during the descending portion of the PGF pulse. This is due to a pulse of LH stimulated by decreased P4, as well as loss of the negative effect of PGF. A complete rebound in P4 occurs after each of a series of pulses of $\mathrm{PGF}_{2 \alpha}$ before the first luteolytic pulse of $\mathrm{PGF}_{2 \alpha}$ (Ginther and Beg, 2013) that causes a terminal decrease in P4. 


\section{Luteal endothelial cells}

Luteal endothelial cells contribute to luteal demise. Endothelial cells express $\mathrm{PGF}_{2 \alpha}$ receptor (Mamluk et al., 1998), and administration of $\mathrm{PGF}_{2 \alpha}$ caused degeneration of these cells (O'Shea et al., 1979) leading to reduced capillary density (Braden et al., 1988) and ultimately to decreased blood flow to the luteal parenchyma. Endothelial cells appear to be one of the first cell types to be affected by $\mathrm{PGF}_{2 \alpha}$ treatment by showing signs of apoptosis (Sawyer et al., 1990). Endothelial cells and more specifically the luteal endothelial cell product endothelial-I (ET-1), could mediate the luteolytic actions of $\mathrm{PGF}_{2 \alpha}$ (Girsh et al., 1995). Choudhary et al., 2005 demonstrated that ET-1 increased concentration of intracellular $\mathrm{Ca}^{+2}$ in bovine luteal steroidogenic cells in vitro. Additionally, SLC and LLC from mature (day-10) CL responded with a greater increase in $\mathrm{Ca}^{+2}$ than SLC and LLC of developing (day-4) CL (Choudhary et al., 2002). However, when different doses of ET-1 or $\mathrm{PGF}_{2 \alpha}$ were administered to bovine luteal endothelial cells in vitro, no differences between the developing (day-4) and mature (day-10) CL were observed (Choudhary et al., 2005). Basal and LH-stimulated P4 were reduced by ET-1 in the developing and mature bovine CL with similar responses (Choudhary et al., 2005). The authors concluded that ET-1 is a tonic inhibitor of P4 secretion rather than a mediator of the action of $\mathrm{PGF}_{2 \alpha}$, and does not contribute to the insensitivity of the developing CL to luteolytic actions.

\section{Luteal immune response}

Immune cells such as macrophages, neutrophils, T cells, and eosinophils are present in both the developing and regressing CL. In the bovine CL, markers of CD5+ or CD8+ T cells increased during stage IV (days 19-21) of the estrous cycle and from day 16 onward in natural luteal regression (Penny et al, 1999). Similarly, markers of leukocytes, specifically macrophages 
and T lymphocytes, significantly increased during luteal regression in cattle (Penny et al., 1999; Bauer et al., 2001). During induced luteolysis of mature bovine CL, mRNA of TNF- $\alpha$, interferon gamma (IFN- $\gamma$ ), and interleukin 1-beta (IL-1 $\beta$ ) were all increased as soon as two hours after injection of $\mathrm{PGF}_{2 \alpha}$ and continued to be elevated throughout 12 hours post $\mathrm{PGF}_{2 \alpha}$ (Neuvians et al., 2004). The wide range in time spanned by this influx of cytokines may indicate that they play roles in both functional and structural regression. Up to $70 \%$ of proliferating cells in the regressing bovine CL are CD14+ macrophages (Bauer et al., 2001). Recruitment of macrophages to the CL by the cytokine monocyte chemoattractant protein 1 (MCP-1) is enhanced by the ability of immune and endothelial cells to interact with one another (Shirasuna et al., 2012). Penny (2000) proposed that on day 18 of the estrous cycle, $\mathrm{PGF}_{2 \alpha}$ acts on various cell types in the CL, such as T-lymphocytes, endothelial cells, fibroblasts, and possibly immune cells directly, to induce MCP-1 production. In the next 24 hours an influx of macrophages occurs in response to MCP-1, which is proposed to serve as an additional source of MCP-1 as well as playing an active role in structural regression (Penny, 2000). Additionally, activated immune cells seem to produce a factor that impairs luteal cell $\mathrm{P} 4$ production because $\mathrm{PGF}_{2 \alpha}$ enhances the production of luteal chemoattractant, and macrophages and eosinophils decrease P4 secretion in the midphase CL in cattle (Pate, 1995).

\section{Signal Transduction Mechanism}

The mechanism governing the action of $\mathrm{PGF}_{2} \alpha$ is thought to involve activation of the phospholipase $\mathrm{C}-\mathrm{Ca}^{2+}$ pathway (Davis et al., 1987). The binding of $\mathrm{PGF}_{2} \alpha$ to its cognate $\mathrm{G}_{\mathrm{q}^{-}}$ protein-coupled receptor causes dissociation of the $\alpha$ subunit from the $\beta / \gamma$ subunit. The $\alpha$ subunit exchanges GDP for GTP to activate phospholipase C (PLC; Davis et al., 1988). Then, PLC cleaves plasma membrane-bound phosphatidylinositol 4,5-bisphosphate $\left(\mathrm{PIP}_{2}\right)$ to generate free 
IP3 (Berridge et al., 1983) and membrane-bound 1,2-diacylglycerol (DAG) (Berridge, 1987). Increase in both the concentration of cytoplasmic $\mathrm{Ca}^{2+}$ and activation of PKC are, in part, intracellular mediators of the actions of $\mathrm{PGF}_{2 \alpha}$ in luteal cells (Wiltbank et al., 1990). Even though it is generally referred to as PKC in signal transduction pathways, $\mathrm{PKC}$ is a family of protein kinases that can be divided into three subfamilies: classic (cPKC; $\alpha, \beta \mathrm{I}, \beta \mathrm{II}$, and $\gamma$ ), novel (nPKC; $\delta, \varepsilon, \eta$, and $\theta$ ), and atypical (aPKC; $\zeta, 1$, and $\lambda$ ) (Kang, 2014). Sen et al. (2003) hypothesized that differential expression of PKC isozymes during the estrous cycle might explain inability of the developing CL to mount the same luteolytic response to $\mathrm{PGF}_{2} \alpha$ that is seen in the mature CL. Indeed, both PKC $\varepsilon$ and PKC $\beta I I$ were expressed at higher concentrations in the mature CL (day 10) compared to the developing CL (day 4). In both developing and mature $\mathrm{CL}, \mathrm{PGF}_{2} \alpha$ had the capacity to activate conventional PKC isozymes. Therefore the authors reasoned that these isozymes do not contribute to the insensitivity of developing CL to luteolytic actions of $\mathrm{PGF}_{2} \alpha$ (Sen et al., 2003). Specific inhibitors of PKC $\varepsilon$ significantly decreased the $\mathrm{PGF}_{2} \alpha$-induced rise in intracellular $\mathrm{Ca}^{+2}$ in LLC and SLC that in turn had consequences (at least in part) in the ability of $\mathrm{PGF}_{2} \alpha$ to inhibit LH-stimulated P4 secretion at this developmental stage (Sen et al., 2005). Additionally, downregulating expression of PKC $\varepsilon$ reduced the ability of $\mathrm{PGF}_{2} \alpha$ to inhibit $\mathrm{P} 4$ synthesis/secretion (Goravanahally et al., 2007).

In other studies, the next intracellular mediator, cytosolic $\mathrm{Cat}^{+2}$, was investigated. Developmental differences in the ability of $\mathrm{PGF}_{2} \alpha$ to induce increases in intracellular $\mathrm{Ca}^{+2}$ have been demonstrated in both LLC and SLC (Choudhary et al., 2005). In vitro, $\mathrm{PGF}_{2} \alpha$ evoked a larger increase in intracellular $\mathrm{Ca}^{+2}$ in both SLC and LLC from mature (day-10) than developing (day-4) CL, and percentage of day-10 SLC responding increased as a function of $\mathrm{PGF}_{2} \alpha$ concentration (Choudhary et al., 2005). 
Goravanahally et al., (2009) provided evidence that the luteolytic actions of increases in intracellular $\mathrm{Ca}^{2+}$ may be mediated through calmodulin dependent kinase kinase 2 beta (CAMKK2) because mRNA expression of CAMKK2 was upregulated in mature versus developing bovine CL. Additionally, CAMKK2 gene expression was upregulated in mature bovine $\mathrm{CL}$ when $\mathrm{PGF}_{2 \alpha}$ was administered in vivo 24 hours before $\mathrm{CL}$ removal (Goravanahally et al., 2009). Whether CAMKK2 affects steroidogenesis directly or indirectly by acting upon another intermediary target is not known. One such target is adenosine monophosphate activated protein kinase (AMPK; Wong, 2009) and it is a possible mediator for the luteolytic actions of $\mathrm{PGF}_{2 \alpha}$.

\section{$\mathrm{PGF}_{2 \alpha}$ signal transduction pathway}

\section{Adenosine monophosphate activated protein kinase (AMPK)}

Adenosine monophosphate activated protein kinase is an important regulatory protein for cellular energy balance in multiple cell types. In all eukaryotic cells, AMPK is a heterotrimeric complex composed of one catalytic subunit $\alpha$ (with two isoforms: PRKAA1 and PRKAA2), and two regulatory subunits $\beta$ (with two isoforms: PRKAB1 and PRKAB2) and $\gamma$ (with three isoforms: PRKAG1, PRKAG2, and PRKG3) (Wong et al., 2009). Different types of cells and tissues express distinctly different combinations of these subunits. Activation of AMPK by phosphorylation of threonine 172 of the $\alpha$ subunit by upstream kinases, LKB1 or CAMKK2, is required for its activity (Wong et al., 2009). A serine/threonine kinase, LKB1, is the primary upstream kinase of AMPK and appears to be constitutively active (Hardie, 2008). When energy concentrations are depleted resulting in a decrease in ATP along with an increase in AMP, LKB1 phosphorylates $\mathrm{Thr}^{172}$.

Specific tissues, such as neurons and endothelial-derived cells, express an alternate 
pathway for activation of AMPK (Hardie, 2008). Increases in cytoplasmic $\mathrm{Ca}^{+2}$ lead to activation of CAMKK2, which is capable of phosphorylating AMPK at $\mathrm{Thr}^{172}$. Free catalytic $\alpha$ subunits are usually inactive due to the presence of an autoinhibitory domain that is located in the center of the subunit. Autoinhibition is eliminated when the $\alpha$ subunit forms a functional complex with the $\beta$ and $\gamma$ subunits. The $\beta$ subunit has key autoregulatory function in the AMPK complex, partially due to a specific sequence that binds to glycogen molecules (Guzman et al., 2009). A myristoylation site serves as a switch for reversible membrane binding of the complex, and a direct autoihibitory domain is located within the $\beta$ subunit (Guzman et al., 2009). The $\gamma$ subunit is defined by the two Bateman domains, which selectively bind molecules that contain adenosine such as AMP or ATP (Bateman, 1997). The binding of AMP to the $\gamma$ subunit activates AMPK by inducing conformational changes in the complex that promote phosphorylation of $\mathrm{Thr}^{172}$. Binding of ATP inhibits these changes. Phosphorylation by AMPK of proteins that inhibit anabolic processes, such as those involved in metabolic pathways that reduce protein synthesis and cell proliferation and increase catabolic pathways that create energy such as glucose uptake, mitochondrial biogenesis, glycolysis and lipid oxidation (Hardie, 2008). Recently, activated AMPK has been shown to decrease P4 secretion in rat, cow, and primary F1 hen granulosal cells (Tosca et al., 2005; Tosca et al., 2007; Tosca et al., 2006). All subunits and their isoforms of AMPK have been characterized in bovine whole ovary, CL, small and large follicles as well as granulosal cells (Tosca et al., 2007).

\section{Pharmaceutical agents}

Thiazolinediones (TZDs) have been used as a form of medication for type II diabetes mellitus since the 1990 's. This is the only approved use, TZD is being experimentally tested to treat polycystic ovarian syndrome (PCOS; Belfort et al., 2006), autism (Boris et al., 2007), and 
ovarian hyperstimulation syndrome (Shah et al., 2010). Peroxisome proliferator-activated receptors (PPAR), which are endogenously activated by free fatty acids and prostanoids, are also activated by TZDs. Once activated, PPAR dimerizes with retinoid X receptor (RXR) to induce a specific cohort of gene expression. In general, TZDs decrease triglycerides and increase highdensity lipoprotein cholesterol (HDL-C).

Dorsomorphin dihydrochloride (DM), also known as Compound C, is a potent selective, cell-permeable and reversible AMPK inhibitor (Liu et al., 2014). Dorsomorphin inhibited AMPK induced either by 5-aminoimidazole-4-carboxamide-1- $\beta$-4-ribofuranoside (AICAR) (Tang et al., 2011) and metformin (Isakovic et al., 2007). However, DM inhibited other kinases in addition to AMPK (Bain et al. 2007).

One cell-permeable allosteric activator of AMPK is AICAR. It is metabolized intracellularly to ZMP (5-aminoimidazole-4-carboxamide-1- $\beta$-D-ribofuranotide) by adenosine kinase (Merrill et al., 1997). Phosphorylated AICAR, ZMP, is an AMP analog that interacts with the $\gamma$ subunit of AMPK and induces kinase activation through allosteric changes in AMPK conformation (Merrill et al., 1997). Although AICAR is used extensively in the laboratory, it is not ideal for clinical scenarios because of its short half-life, requirement for intravenous infusion, and variable effectiveness among patients (Wong et al., 2009).

Metformin is another well-known activator of AMPK, although it activates the heterotrimeric complex indirectly. Metformin is a biguanide that is developed from galegine, which is a derivative of the guanidine found in Galega officinalis (French lilac). Metformin specifically works in the mitochondria by inhibiting the mitochondrial respiratory chain complex I. Although the exact mechanism of action has yet to be elucidated, metformin inhibits complex I without affecting any other steps in the respiratory chain (Viollet et al., 2012). Ultimately, 
metformin reduces the synthesis of ATP by decreasing not only NADH oxidation but also proton pumping across the inner mitochondrial membrane and rate of oxygen consumption (Viollet et al., 2012). This reduction in ATP results in a shift in the AMP: ATP ratio and causes the AMPK complex to become phosphorylated and therefore active (Viollet et al., 2012).

Metformin is the most widely used drug for the treatment of type II diabetes, being prescribed to nearly 120 million people worldwide (Viollet et al., 2012). It inhibits hepatic gluconeogenesis and augments the rate of glucose uptake in skeletal muscle (Bailey, 1996). Recently, metformin was used to treat women experiencing PCOS who were overweight or insulin resistant. Metformin's ability to increase insulin sensitivity in individuals made it an ideal candidate for the treatment of PCOS. Metformin increased insulin sensitivity in patients with PCOS and it increased ovulation rate, improved menstrual cyclicity, and reduced serum androgen (Tang et al., 2010). However, in 2007 Legro et al. showed that clomiphene citrate was superior to metformin in achieving live birth rates in infertile women with PCOS. Metformin appears to work in PCOS patients by both direct ovarian effects and secondarily through decreasing insulin resistance. In bovine granulosal cells isolated from small antral follicles steroidogenesis was affected by metformin treatment (Tosca et al., 2007). Metformin (10 mM) reduced both $\mathrm{P} 4$ and $\mathrm{E}_{2}$ production as well as key enzymes (HSD3 $\beta$, CYP11A1, and STAR), with or without FSH and/or IGF1 in the media (Tosca et al. 2007).

Interestingly, metformin is a hydrophilic base that is excreted unchanged in the urine. Metformin cannot easily diffuse through cell membranes and is not metabolized into other variants when being eliminated from the body (Gruzman et al., 2009). Metformin is a small molecule that has many transporters, known as organic cation transporters, in the kidney that lead to its high rate of renal clearance (Wong et al., 2009). 


\section{Model of activation of AMPK in the corpus luteum}

Changes in P4 biosynthesis due to activation of AMPK in the bovine CL stem from increases in intracellular $\mathrm{Ca}^{+2}$. In addition to activating $\mathrm{PKC}$, rises in $\mathrm{Ca}+2$ activate calmodulin and therefore CAMKK. The latter is responsible for phosphorylating AMPK and converting it to its active form that traditionally monitors the energy balance of the cell, but AMPK may not have this role in steroidogenic cells. Typically, activation of AMPK results in a shift from anabolic processes, such as synthesis of proteins like enzymes involved in $\mathrm{P} 4$ production, to catabolic processes. Additionally, AMPK activation leads to phosphorylation of fatty acid synthase (FAS), and acetyl-CoA-carboxylase (ACC1), key enzymes in de novo lipid synthesis. It may also regulate cholesterol uptake through lipoprotein receptors. Progesterone is a steroid hormone and is derived from cholesterol that is made up of lipids. This provides another mechanism to reduce overall P4 production (Figure 1.0).

\section{Statement of the problem}

The literature established that developmental differences exist in multiple facets of physiology between developing and mature bovine CL. Changes in FP expression or $\mathrm{PGF}_{2 \alpha}$ ligand, luteal blood flow, endothelial system, immune system, and the signal transduction mechanism have all been investigated in an attempt to explain the insensitivity of the developing $\mathrm{CL}$ to a luteolytic dose of $\mathrm{PGF}_{2 \alpha}$. However, FP receptor expression is similar among developing and mature bovine $\mathrm{CL}$, and, furthermore, $\mathrm{PGF}_{2 \alpha}$ - mediated actions have been demonstrated at these two luteal developmental stages Therefore, a difference in the components of the signal transduction mechanim activated by $\mathrm{PGF}_{2 \alpha}$ upon binding to its cognate $\mathrm{FP}$ exits between developing and mature CL. In agreement with this idea, $\mathrm{PGF}_{2 \alpha}$ elicited a difference in $\mathrm{Ca}^{+2}$ 
response between the two developmental stages of the bovine CL, and a down-stream target of $\mathrm{Ca}^{+2}, \mathrm{CAMMK} 2$, was differentially expressed in developing and mature CL. CAMKK2 is known to phosphorylate AMPK, but this component of the signal transduction pathway has not been investiaged in relation to reproductive endocrinology. Therefore, the goal of this project is to investigate alternative downstream components activated by the rise in cytosolic $\left[\mathrm{Ca}^{2+}\right]$ initiated when the FP receptor is activated in both bovine luteal tissue and luteinized human granulosal cells. The objectives of the research were: to determine the changes in $\mathrm{P} 4$ secretion in vitro and in vivo in the presence of an AMPK inhibitor or activator in developing and mature bovine CL; define changes in AMPK that occur as a result of FP activation; define changes in cholesterol transport that occur as a result of $\mathrm{PGF}_{2 \alpha}$ binding to FP, which may be monitored by AMPK; define culture conditions and responses to luteotropic and luteolytic signals by luteinized human granulosal cells derived from patients with various infertility causes. The proposed research has one central hypothesis: developmental differences in components of the signal transduction associated with FP expressed in developing and mature CL explain, at least in part, the developmental difference in the ability of $\mathrm{PGF}_{2 \alpha}$ to induce functional luteal regression. 


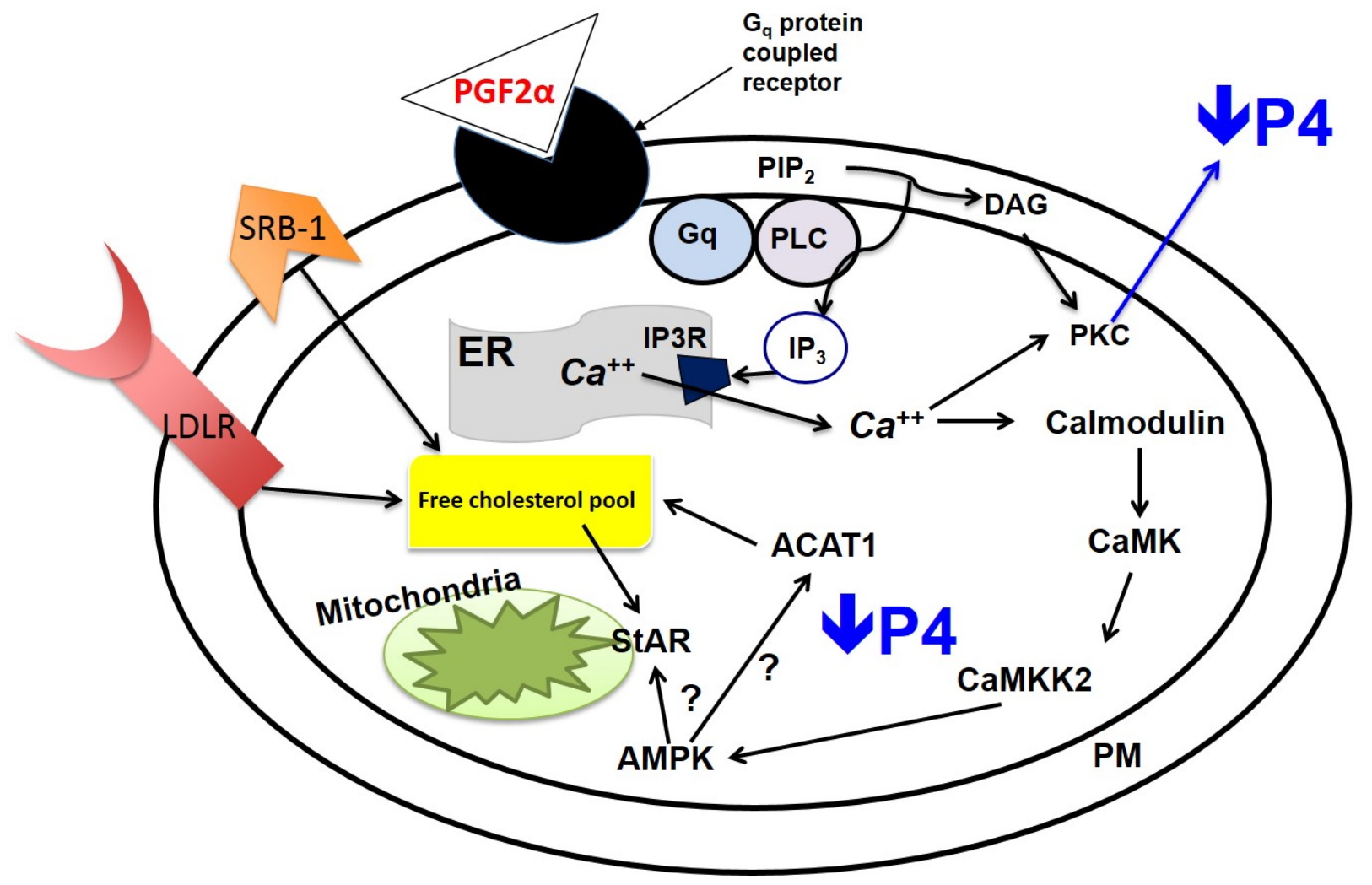

Figure 1.0: Model of actions of AMPK in luteal cells. Changes in progesterone biosynthesis due to activation of AMPK in the bovine CL stem from increases in intracellular $\mathrm{Ca}^{+2}$, calmodulin, and CAMKK2. CAMKK2 phosphorylates AMPK and converting it to its active form results in a shift from anabolic processes to catabolic processes. Additionally, AMPK may regulate cholesterol uptake through lipoprotein receptors (LDLR and SRB-1). This provides another mechanism to reduce overall progesterone production in addition to the established role of PKC. 


\section{Chapter 2: Effects of prostaglandin $F 2$ alpha and adenosine monophosphate activated kinase on progesterone production in the bovine corpus luteum in vivo}

\section{Introduction}

The ability of bovine corpus luteum (CL) to respond to luteolytic actions of prostaglandin F 2 alpha $\left(\mathrm{PGF}_{2 \alpha}\right)$ increases after ovulation in cattle. Developing CL (days 1-5) fail to regress if a single exogenous bolus of $\mathrm{PGF}_{2 \alpha}$ is given, yet administration of $\mathrm{PGF}_{2 \alpha}$ at the same dose when the $\mathrm{CL}$ is at the mature stage (days 6-15) will induce regression with the cow returning to estrus within 48-72 hours (Rowson et al., 1972; Inskeep, 1973). The cellular mechanisms responsible for this developmental difference are unclear. Lack of receptors (Wiltbank, 1995; Juengel et al., 1998; Wright et al., 2014) or ability to elicit a physiological response to $\mathrm{PGF}_{2 \alpha}$ (Tsai and Wiltbank, 1998; Choudhary et al., 2005; Sen et al., 2005) does not appear to explain the observed differences. As discussed below, differences in the signal transduction mechanisms associated with FP receptor might explain some of the characteristics of the elicited response to $\mathrm{PGF}_{2 \alpha}$ in mature versus developing CL.

In luteal cells, $\mathrm{PGF}_{2 \alpha}$ has affects by binding to its cognate $\mathrm{G}_{\mathrm{q}}$ protein-coupled receptor and activating phospholipase C (PLC; Davis et al., 1988). Then, PLC cleaves plasma membrane-bound phosphatidylinositol 4,5-bisphosphate $\left(\mathrm{PIP}_{2}\right)$ to generate free IP3 (Berridge et al., 1983) and membrane-bound 1,2-diacylglycerol (DAG) (Berridge, 1987). Water-soluble IP3 increases the concentration of cytoplasmic $\mathrm{Ca}^{2+}$, and $\mathrm{DAG}$, which in combination with $\mathrm{Ca}^{2+}$, activates protein kinase $\mathrm{C}(\mathrm{PKC})$. Increases in both cytoplasmic $\mathrm{Ca}^{2+}$ and activation of PKC have been demonstrated, in part, to mediate the actions of $\mathrm{PGF}_{2 \alpha}$ in luteal cells (Wiltbank et al., 1990). Differential expression of genes encoding particular isoforms of PKCs and genes 
participating in $\mathrm{Ca}^{2+}$ homeostasis have been implicated in acquisition of luteolytic capacity by the bovine CL. In agreement with this suggestion, increased expression of two PKC inhibitors, histidine triad nucleotide binding protein (H1NT1) and tyrosine 2-monooxygenaseltryptophan 5monooxygenase activation protein zeta polypeptide (YWHAZ), appear to be involved in insensitivity of the early ovine CL (Juengel et al., 1998). Indeed, YWHAZ gene expression was downregulated in mature bovine CL (Goravanahally et al., 2009). Greater concentrations of $\mathrm{PGF}_{2 \alpha}$ are needed to elicit $\mathrm{Ca}^{2+}$ responses in steroidogenic cells isolated from developing than from mature CL (Choudary et al., 2005). Additionally, increased gene expression of CAMKK2, a down-stream target of $\mathrm{Ca}^{2+}$, is more relevant in the activated signal transduction pathway in mature than in developing CL (Goravanahally et al., 2009). After an agonist-mediated rise in intracellular $\mathrm{Ca}^{2+}$ CAMKK2 was activated via phosphorylation by calcium/calmodulindependent kinases (CAMKs) Whether CAMKK2 affects steroidogenesis directly or if it acts upon another intermediary step that impinges on steroidogenesis is not known.

One intermediary step could be activated adenosine monophosphate activated kinase (AMPK), which is activated via phosphorylation by CAMKK2 (Wong, 2009). Typically, activation of AMPK results in a shift from anabolic processes, such as protein synthesis or progesterone production, to catabolic processes. Activation of AMPK may regulate progesterone production by altering cholesterol uptake through high and low-density lipoprotein receptors such as scavenger receptor class B member 1 (SRB-1) and low-density lipoprotein receptor (LDLR). Cholesterol influx is critical in steroidogenic cells because it is the preferred source over de novo synthesis in this tissue. Both LDL and HDL provide substrate for progesterone production. During luteal regression in primates, gene expression for lipoprotein receptors SRB1 and LDLR decreased (Bogan et al., 2009, 2010). Downregulation of LDLR activity in human 
fibroblast cells increased expression of acyl CoA cholesterol acyltransferase (ACAT) (Brown et al., 1975), which is responsible for esterification of free cholesterol. These cholesterol esters are stored in lipid droplets and are hormonally regulated in steroidogenic cells of the adrenal, ovary and testis (Behrman and Greep, 1972; Hou et al., 2010). The possibility that $\mathrm{PGF}_{2 \alpha}$ predicates luteolytic actions of AMPK regulation changes in cholesterol transport has yet to be explored in the bovine CL.

One well known activator of AMPK is metformin, which is the most widely used pharmaceutical for treatment of type II diabetes being prescribed to nearly 120 million people worldwide (Viollet et al., 2012). Metformin activates AMPK by reducing synthesis of ATP through NADH oxidation, which results in a shift in AMP: ATP ratio and phosphorylation of the AMPK complex (Viollet et al., 2012). In addition, metformin has been used to treat polycystic ovary syndrome (PCOS) in women who were overweight or insulin resistant. Metformin directly affects the ovaries and also decreases insulin resistance in PCOS patients. Additionally, metformin has been shown to reduce progesterone and estradiol production in bovine granulosal cells isolated from small antral follicles (Tosca et al., 2007). Reduced steroidogenesis resulting from metformin treatment indicates a potential role in progesterone production in the bovine ovary.

Therefore, the objective of this study was to investigate if AMPK played a role in the signal transduction pathway used by FP receptors in mature bovine CL. The specific aims of this research were to determine changes in progesterone secretion in vivo in response to activation of AMPK via metformin in mature bovine CL; define changes in protein expression of AMPK, phosphorylated AMPK (P-AMPK) and steroidogenic acute regulatory (StAR) resulting from FP activation, and characterize cholesterol transport proteins (LDL, SRB-1, ACAT-1) during 
functional regression after activating $\mathrm{FP}$ via exogenous $\mathrm{PGF}_{2 \alpha}$. The overall hypothesis is that luteal developmental differences in signal transduction associated with FP can explain, at least in part, the differences in the ability of $\mathrm{PGF}_{2 \alpha}$ to induce functional luteal regression in the mature but not the developing bovine CL.

\section{Materials and Methods}

Non-lactating beef cows were observed twice daily for estrus at approximately $12 \mathrm{~h}$ intervals for 30 min per observation. The day when standing estrus was observed was designated as day 0 (d0). The West Virginia University Animal Care and Use Committee reviewed and approved the protocol for the tissue collection (ACUC \# 01-0809).

\section{Experiment 1}

Cows (450-700 kg BW) were assigned randomly among treatment groups: day 10 hour 0 $(\mathrm{d} 10-\mathrm{h} 0 ; \mathrm{n}=5)$, day 10 hour $2(\mathrm{~d} 10-\mathrm{h} 2 ; \mathrm{n}=5)$, day 10 hour $4(\mathrm{~d} 10-\mathrm{h} 4 ; \mathrm{n}=5)$. Cows received a subcutaneous injection of $\mathrm{PGF}_{2 \alpha}$ (25 mg, Lutalyse ${ }^{\circledR}$; Zoetis Florham Park, NJ) or saline (d10-h0) 0,2 , or 4 hours prior to lutectomy. Corpora lutea (CL) were collected via supravaginal incision under epidural anesthesia (Casida, 1959) with administration of 6-9 $\mathrm{mL}$ of $2 \%$ lidocaine (Butler Company, Columbus, $\mathrm{OH})$. CL were weighed and divided into equal sections for protein isolation and measurement of luteal progesterone. Tissue for protein isolation was snap frozen in liquid nitrogen and stored at $-80^{\circ} \mathrm{C}$; remaining tissue was transported to the laboratory in ice-cold saline. Tissue for luteal P4was homogenized with an Omni Tissue Homogenizer (Omni International, Kennesaw, GA) and then frozen at $-20^{\circ} \mathrm{C}$ until assayed for P4via RIA. Blood samples were collected hourly via caudal venipuncture until CL excision. Samples were allowed to clot and then centrifuged at $3500 \times \mathrm{g}$ for 15 minutes, and serum was collected and stored at $20^{\circ} \mathrm{C}$. Serum and CL assayed by RIA for P4 as previously described (Sheffel et al., 1982). 
Luteal proteins were analyzed using semiquantitative Western blotting as previously described (Sen, 2004). Briefly, protein was isolated from d10-h0, d10-h2 and d10-h4 CL by homogenizing the luteal tissue in a buffer containing $50 \mathrm{mM}$ Tris $\mathrm{HCl}, 150 \mathrm{mM} \mathrm{NaCl}, 1 \mathrm{mM}$ EGTA, 1 mM EDTA, $0.1 \%$ SDS, $1 \%$ Triton-X, protease inhibitors (2 mM phenylmethylsulfonylfluoride, $5 \mu \mathrm{g} / \mu \mathrm{l}$ leupeptin, $5 \mu \mathrm{g} / \mu \mathrm{l}$ aprotinin), and phosphatase inhibitors (100 mM sodium fluoride, $2 \mathrm{mM}$ sodium orthovanadate, $10 \mathrm{mM}$ sodium pyrophosphate). Sample protein concentration was determined using a Bio-Rad (Hercules, CA) assay with bovine serum albumin (BSA; Gibco BRL) as a standard. After concentrations were determined, $100 \mu \mathrm{g} / \mathrm{lane}$ of protein was loaded for StAR, AMPK, P-AMPK, SRB-1, and LDLR. Proteins were resolved with a 4-15\% gradient polyacrylamide TGX gel (Bio-Rad, Hercules, CA) and transferred to polyvinylidene difluoride (PVDF) membrane (Millipore, Billerica, MA) using a Bio-Rad Mini Trans-Blot Cell (Hercules, CA).

Primary antibodies used included 1) StAR antibody (\#bs-3670R, Bioss, Boston, MA) at 1:250 (v/v) 2) AMPK antibody (\#2532S, Cell Signaling Technology, Danvers, MA) 1:1000 (v/v) 3) P-AMPK antibody (\#2537S, Cell Signaling Technology, Danvers, MA) 1:1000 (v/v) 4) LDLR antibody (LS-C146979, LSBio, Seattle, WA) 1:500 (v/v) 5) SRB-1 antibody (\#ab24603, AbCam, Cambridge, MA) (1:1000) 6) and beta actin (A2228; Sigma-Aldrich, St. Louis, MO) at a dilution of 1:2000 (v/v) and incubated overnight at $4^{\circ} \mathrm{C}$ with gentle shaking. Secondary antibodies included goat anti-mouse IRDye 680RD (for actin) diluted to 1:10000 and goat antirabbit IRDye 800CW (for StAR, AMPK, P-AMPK, LDL-R, SRB-1) diluted to 1:10000 (v/v) (\#926-68170, \#827-08365, Li-Cor, Lincoln, NE). A two-color detection scheme was used to permit simultaneous probing for target proteins. Band intensity imaging was captured using Odyssey infrared imaging software and quantified through densitometry (ImageJ Bethesda, 
Maryland). Signal intensity for a protein of interest was standardized to the corresponding intensity of actin in the same sample. This normalization procedure for semiquantitative estimation of protein was validated by Sen et al. (2004).

\section{Materials and Methods}

Non-lactating beef cows were observed twice daily for estrus at approximately $12 \mathrm{~h}$ intervals for 30 min per observation. The day of standing estrus was designated as day $0(\mathrm{~d} 0)$. The West Virginia University Animal Care and Use Committee reviewed and approved the protocol for the tissue collection (ACUC \# 12-1008).

\section{Experiment 2}

Cows were assigned randomly to treatment groups, which received $15($ Met-15, $\mathrm{n}=4)$ or 30 (Met-30, n = 4) mg/kg of BW of metformin (New England Mail Order Pharmacy, Middlebury, VT) every 3 hours for 12 hours on d 10 of the estrous cycle. Metformin was pulverized and dissolved into sterile saline solution before centrifugation at $119 \mathrm{RCF}$ for 5 minutes to remove non-active binding ingredients. Supernatant was collected for infusion, the pellet was washed; and the supernatant was collected and added to the total infusion volume. An artificial insemination catheter was passed through the cervix, and metformin was deposited into the uterus by a syringe connected to the catheter by a $200 \mu$ l pipette tip. Based on observations from this study, a dose of $30 \mathrm{mg} / \mathrm{kg} \mathrm{BW}$ of metformin (metformin, $\mathrm{n}=7$ ) or saline (control, $n=7)$ was injected into the jugular vein of cows $(n=7)$ every $3 \mathrm{~h}$ for 12 hours. Blood samples were collected one day prior to and hourly for $12 \mathrm{~h}$ after the first metformin infusion and then one and two days after treatment. Blood samples were allowed to clot, and then centrifuged at $3500 \mathrm{x}$ $g$ for 15 min. Serum was collected and stored at $-20^{\circ} \mathrm{C}$ until assayed by RIA for P4 (Sheffel et al., 1982) and for metformin (Amini et al., 2005). Serum concentrations of insulin were 
determined by RIA kit (Insulin Coat-A-Count; Diagnostics Products Corporation; Los Angeles, CA). Signs of estrus were monitored daily for 2 weeks after treatment.

\section{Statistical Analysis}

Normalized protein concentrations ratios were tested for normal distribution via the Shapiro-Wilk test (Shapiro and Wilk, 1965). A one-tailed Student's $t$-test was used for comparison of data sets that had a normal distribution. For data sets that did not have a normal distribution, a one-tailed Wilcoxon two-group test (Mann-Whitney test) was used. Concentrations of serum P4 was examined using ANOVA with repeated measures, and serum concentrations of insulin, as well as luteal P4 content, was examined using ANOVA with Dunnett's Method post hoc test. Data were analyzed using JMP and SAS software (JMP®), Version Pro 11, SAS Institute Inc., Cary, NC, Copyright (C2013; SAS®, Version 9.3, SAS Institute Inc., Cary, NC, Copyright (C2002-2010). Significance criterion alpha for all tests was 0.05. Data are depicted as the mean \pm SEM.

\section{Results}

\section{Experiment 1}

A decrease in serum P4concentration and luteal P4content at $2 \mathrm{~h}(2.08 \mathrm{ng} / \mathrm{ml} \mathrm{vs} .2 .96$ $\mathrm{ng} / \mathrm{ml} ; P=0.054)$ and $4 \mathrm{~h}(1.57 \mathrm{ng} / \mathrm{ml}$ vs. $2.96 \mathrm{ng} / \mathrm{ml} ; P=0.013)$ was observed after PGF $_{2 \alpha}$ administration $(\mathrm{d} 10-\mathrm{h} 0=5.05 \mathrm{ng} / \mathrm{ml} ; \mathrm{d} 10-\mathrm{h} 2=2.03 \mathrm{ng} / \mathrm{ml} ; \mathrm{d} 10-\mathrm{h} 4=1.74 \mathrm{ng} / \mathrm{ml})$ (Figure 1.1). Changes in protein expression of LDL, SRB-1, AMPK, StAR, and ACAT-1 are shown in Figure 1.2. There was no detection of P-AMPK. A decrease in LDL protein expression was observed at $2 \mathrm{~h}(0.79$ vs. $0.41 ; P=0.09)$ and at $4 \mathrm{~h}$ after $\mathrm{PGF}_{2 \alpha}$ injection $(0.79$ vs. $0.13 ; P=0.004)$ (Figure 1.2-A). An increase in ACAT-1 occurred by $4 \mathrm{~h}(0.67$ vs. $0.21, P=0.010)$ after PGF injection (Figure 1.2-B). There was a significant quadratic effect of treatment and time $(P=0.037)$ for 
AMPK protein expression (Figure 1.2-C). An increase in StAR protein expression was observed $4 \mathrm{~h}(3.62$ vs. $1.25, P=0.01)$ after $\mathrm{PGF}_{2 \alpha}$ injection, but not at $2 \mathrm{~h}(1.02$ vs. 1.74 , Figure $1.2-\mathrm{D})$. There was also a quadratic effect of treatment and time $(P=0.05)$ for StAR protein expression, with $\mathrm{H} 4$ having the highest ratio (Figure 1.2-D). No difference in SRB-1 protein expression occurred at either 2 (1.92 vs. 1.74) or 4 h (2.75 vs. 1.74) after PGF injection (Figure 1.2-E).

\section{Experiment 2}

The preliminary experiment revealed that even though concentrations of metformin were detectable in blood after intrauterine administration, which is shown by the representative HPLC metformin determination from a 30-mg/kg bw cow in Figure 1.3; intravenous administration was simpler. There was a decrease in serum concentrations of $\mathrm{P} 4(P=0.001)$ with $30 \mathrm{mg}(1.01 \pm$ $0.08 \mathrm{ng} / \mathrm{ml})$ of metformin compared to $15 \mathrm{mg}(1.33 \pm 0.08 \mathrm{ng} / \mathrm{ml}$, Figure 1.3). However, days to estrus was not different between the groups $(x=21 \mathrm{~d} \pm 1)$. Figure 1.4 illustrates that in the there was no difference in $\mathrm{P} 4$ between metformin $(0.784 \pm 0.15 \mathrm{ng} / \mathrm{ml})$ and saline $(0.788 \pm 0.29$ $\mathrm{ng} / \mathrm{ml})$. Additionally, there was no difference in insulin concentrations between saline $(4.49 \pm$ $0.154 \mu \mathrm{g} / \mathrm{L})$ and metformin $(4.48 \pm 0.154 \mu \mathrm{g} / \mathrm{L})$ treatments $(P>0.05$; Figure 1.5$)$, or time to return to estrus $(\mathrm{x}=11 \mathrm{~d} \pm 1)$.

\section{Discussion}

These results corroborate that activation of the FP receptor by exogenous $\mathrm{PGF}_{2 \alpha}$ causes a decrease in serum and luteal P4 concentrations (Juengel et al., 1993; Wiltbank et al., 1995; Tsai

and Wiltbank 1998; Atli et al., 2012). Similarly, both serum concentrations and luteal P4 content decreased by 4 hours after $\mathrm{PGF}_{2 \alpha}$ administration. These decreases of both serum and luteal P4 were observed as early as $2 \mathrm{~h}$ after $\mathrm{PGF}_{2 \alpha}$, yet no changes in serum $\mathrm{P} 4$ were observed at $1 \mathrm{~h}$ after $\mathrm{PGF}_{2 \alpha}$ (data not shown). These data established a time frame for the process of functional 
regression after exogenous injection of $\mathrm{PGF}_{2 \alpha}$.

During this functional regression, cholesterol transport through LDLR was lower at 2 and $4 \mathrm{~h}$ after $\mathrm{PGF}_{2 \alpha}$, indicating that substrate transport by these receptors was critical during reduction of P4 production. Lower LDLR would lead to decreased cholesterol, the substrate for P4 production. Decreases in LDL receptors reduce 3-hydroxy-3-methylglutaryl coenzyme A reductase (HMG-CoA reductase), catalyzing a rate-limiting step in cholesterol production (Siperstein, 1970), and increasing ACAT-1 (Brown et al., 1975). Cells adjust to the number of LDL receptors in order to produce sufficient cholesterol for the metabolic need of the cell without over accumulation (Brown and Goldstein, 1975). This function is key because cells are able to keep the concentration of unesterified cholesterol in membranes constant, while requirements and exogenous supply are fluctuating constantly (Goldstein and Brown, 2009). The observed increases of ACAT-1 indicate an attempt by the luteal tissue to compensate for decreases in cholesterol.

No change in SRB-1 in mature CL was observed after $\mathrm{PGF}_{2 \alpha}$ administration. During spontaneous luteolysis in primate CL, changes in gene expression or protein concentrations of SRB-1 were not different between mid-late to functional late CL but were decreased from functional to functionally regressed late stage CL (Bogan et al., 2009, 2010). Functional late CL were defined as having been collected on day 14-16 of the menstrual cycle, and functionally regressed late CL were a subset of those CL from animals with serum P4values less than 0.5 ng/ml (Bogan et al., 2009). Based on the criteria used by Bogan et al. (2009, 2010), the time points used in the current study after $\mathrm{PGF}_{2 \alpha}$ was given, could have reflected functional regression; whereas, the results reported by Bogan et al. reflected structural regression. Expression of AMPK mRNA has been measured in whole bovine ovaries, small and 
large follicles, oocytes, and CL. Additionally, AMPK- $\alpha$ subunit protein expression was detected in small and large follicles and their granulosal cells (Tosca et al., 2007). Previous data indicated a developmental difference in AMPK gene expression between developing and mature CL, with increased expression in mature bovine CL (Goravanhally, unpublished results). Therefore activation of AMPK would have a greater effect in the mature than developing CL. Activation of AMPK using metformin decreased P4 production in bovine granulosal (Tosca et al., 2007) and luteal cells (Hou et al., 2009). Thus, elevated concentrations of AMPK protein observed $2 \mathrm{~h}$ after FP activation may serve as a mechanism by which both serum and luteal P4concentrations are decreased. At $4 \mathrm{~h}$ after FP activation, P4 concentrations decreased such that AMPK activation was not required to mediate further decreases in steroid production. No detection of P-AMPK occurred at either 2 or 4 hours. This may be a result of rapid AMPK phosphorylation. Park et al. (2002) reported AMPK phosphorylation within 5 seconds in skeletal muscle of rats. Therefore, time points chosen after $\mathrm{PGF}_{2 \alpha}$ may have been too late to observe any change in P-AMPK.

Metformin was delivered successfully into the uterine lumen of the cows, and detection of its presence in serum was achieved using HPLC. This delivery method was chosen originally due to the concept that counter-current exchange in the utero-ovarian vein (McCracken et al., 1999) would aid in delivery of metformin to the CL. Despite the fact that metformin was detectable in blood, passing the AI rod through a cow in the luteal phase was technically difficult. Differences in P4 concentration were observed between 15 and 30 (mg/kg of BW) doses of metformin during the preliminary study. The $30 \mathrm{mg}$ dose was chosen based on studies in horses, in which metformin was being used as treatment for insulin resistance (Hustace et al., 2009; Rendle et al., 2013). This observation combined with the lack of visible negative side 
effects of metformin on cows, indicated that a $30 \mathrm{mg} / \mathrm{kg}$ of BW dose would be appropriate for IV administration in subsequent experiments. However, at this dose there was no difference in P4 concentrations between the metformin- and saline-treated cows, and no difference in their time to return to estrus. Additionally, no changes in insulin concentrations after metformin were observed. This was surprising because this same dose caused a significant decrease in insulin concentrations in horses (Rendle et al., 2013). A greater dose of metformin might have elicited a response in both insulin and $\mathrm{P} 4$ production. This would be difficult to test due to the cost prohibitive nature of administering a drug that is used in the human market to treat patients with PCOS (Tang et al., 2010) and diabetes (Viollet et al, 2012).

In summary, activation of the FP receptor caused a decrease in luteal and serum P4concentrations as soon as two hours after exogenous administration $\mathrm{PGF}_{2 \alpha}$. Alterations in cholesterol transport accounted for this reduction, at least in part, in P4production. Changes in AMPK protein during this same time period indicate that it may be the downstream target of FP activation, which controls cholesterol trafficking. 
A

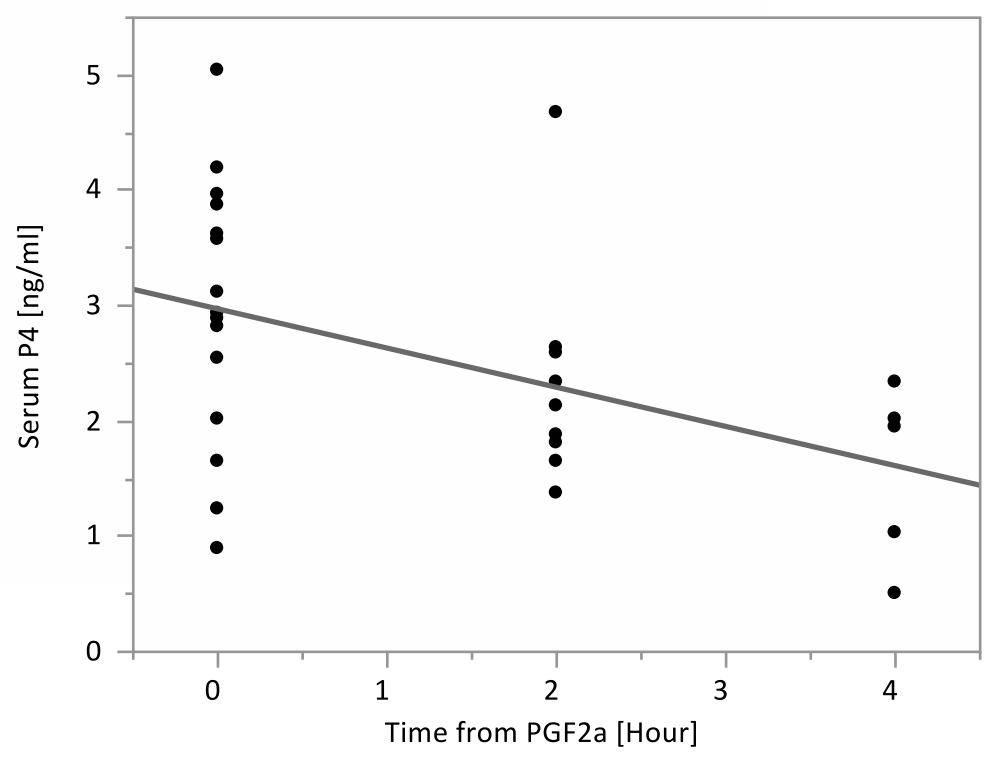

Serum progesterone $(\mathrm{ng} / \mathrm{ml})=2.9742-0.3399 *$ Time from $\mathrm{PGF}_{2 \alpha}($ Hour $)$

B

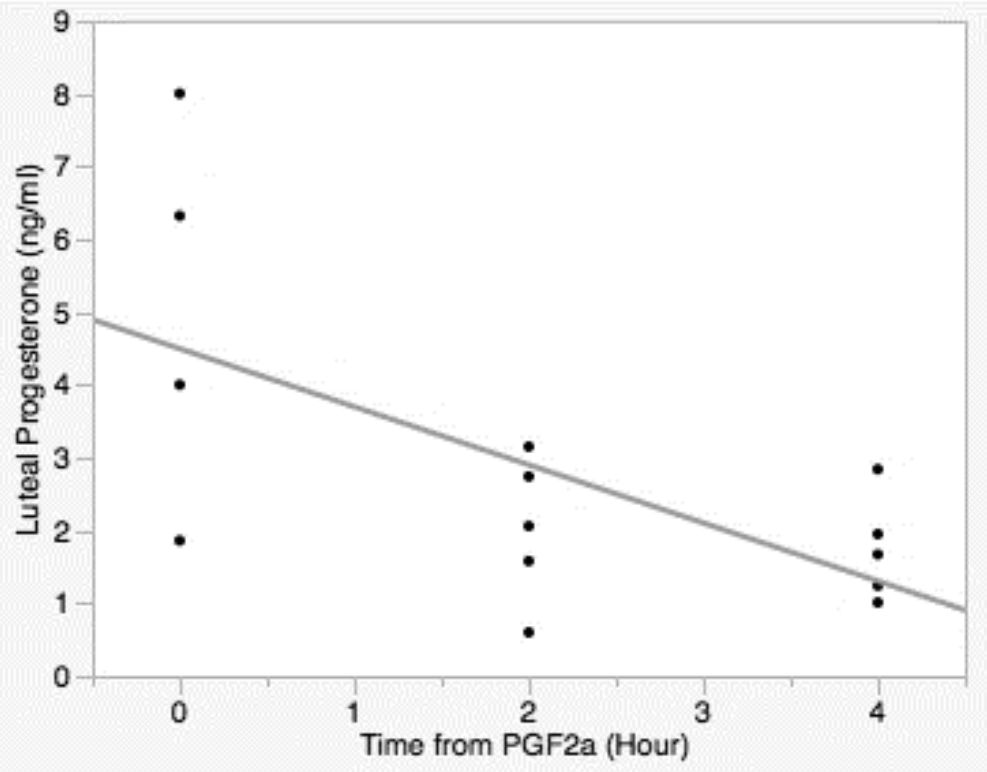

Luteal progesterone $(\mathrm{ng} / \mathrm{ml})=4.498-0.7984 *$ Time from $\mathrm{PGF}_{2 \alpha}($ Hour $)$

Figure 1.1: Bivariate fit of serum (A) and luteal (B) P4 (ng/ml) by time from PGF $_{2 \alpha}$ (hour). Significant declines in serum and luteal progesterone occurred at both 2 and 4 hours after PGF $_{2 a}$. 
A

B
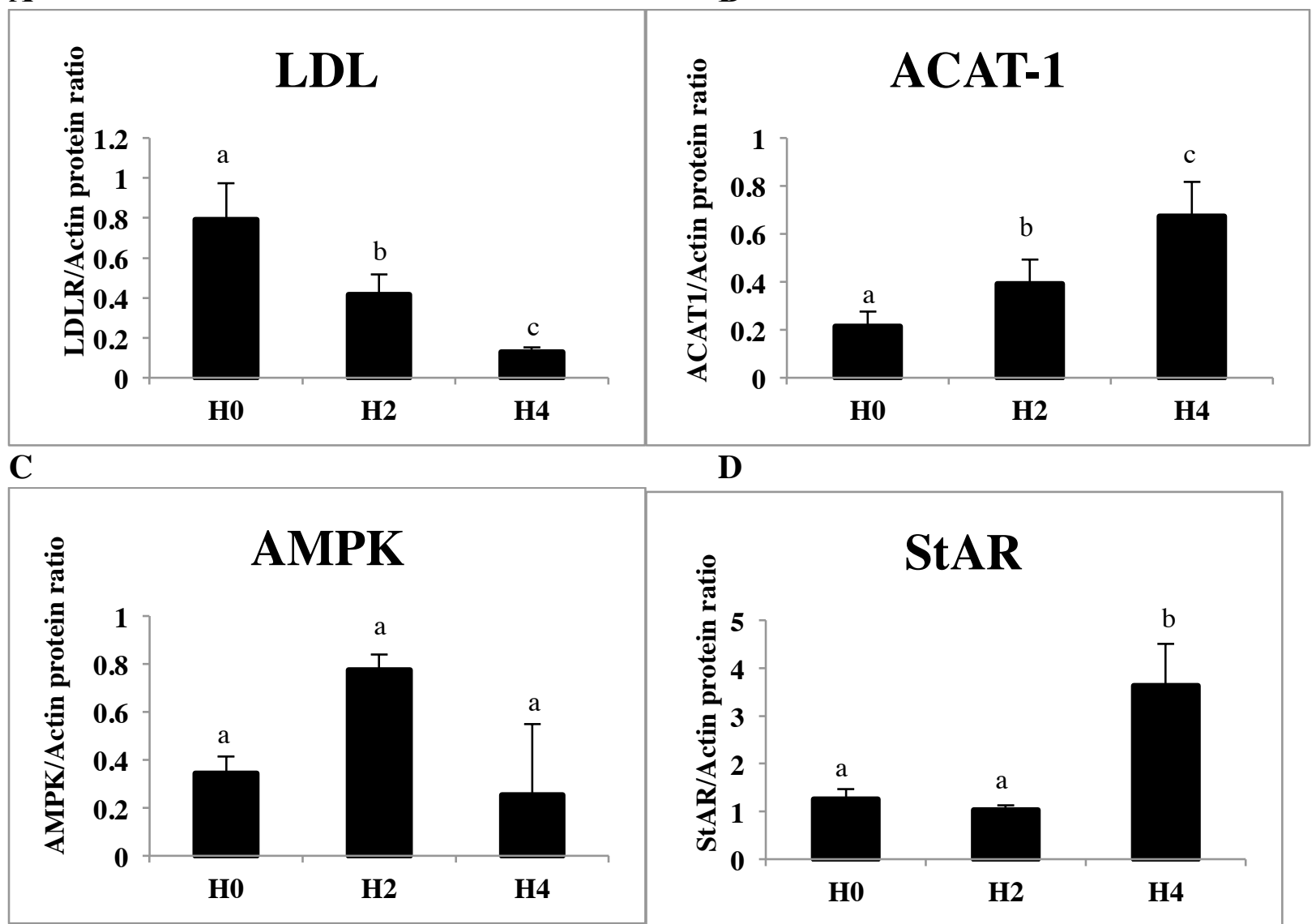

$\mathbf{E}$

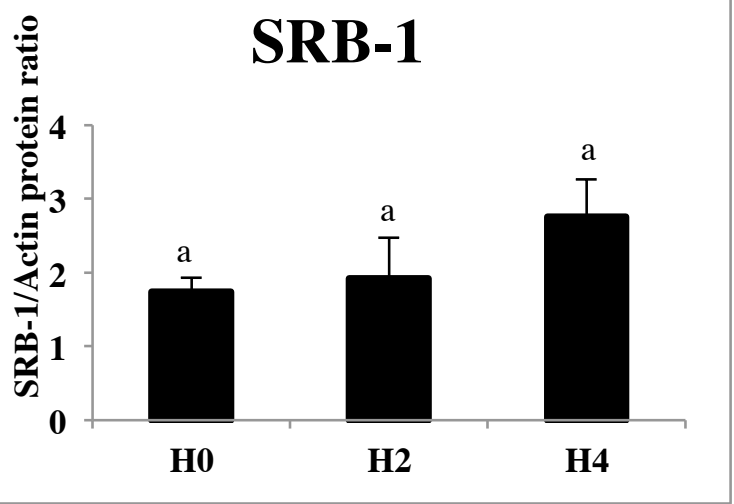

Figure 1.2: Semiquantitative analysis of the densitometric data derived from Western blots using protein samples isolated mature bovine $\mathrm{CL} 0,2$, and 4 hours after $\mathrm{PGF}_{2 \alpha}$. The $y$-axis shows the ratio of the optical density (o.d.) for the protein of interest corrected by the detected o.d. for its corresponding actin. The data are given as mean \pm SEM; values with differing letters denote statistically significant differences $(\mathrm{P}<0.001)$. 
A

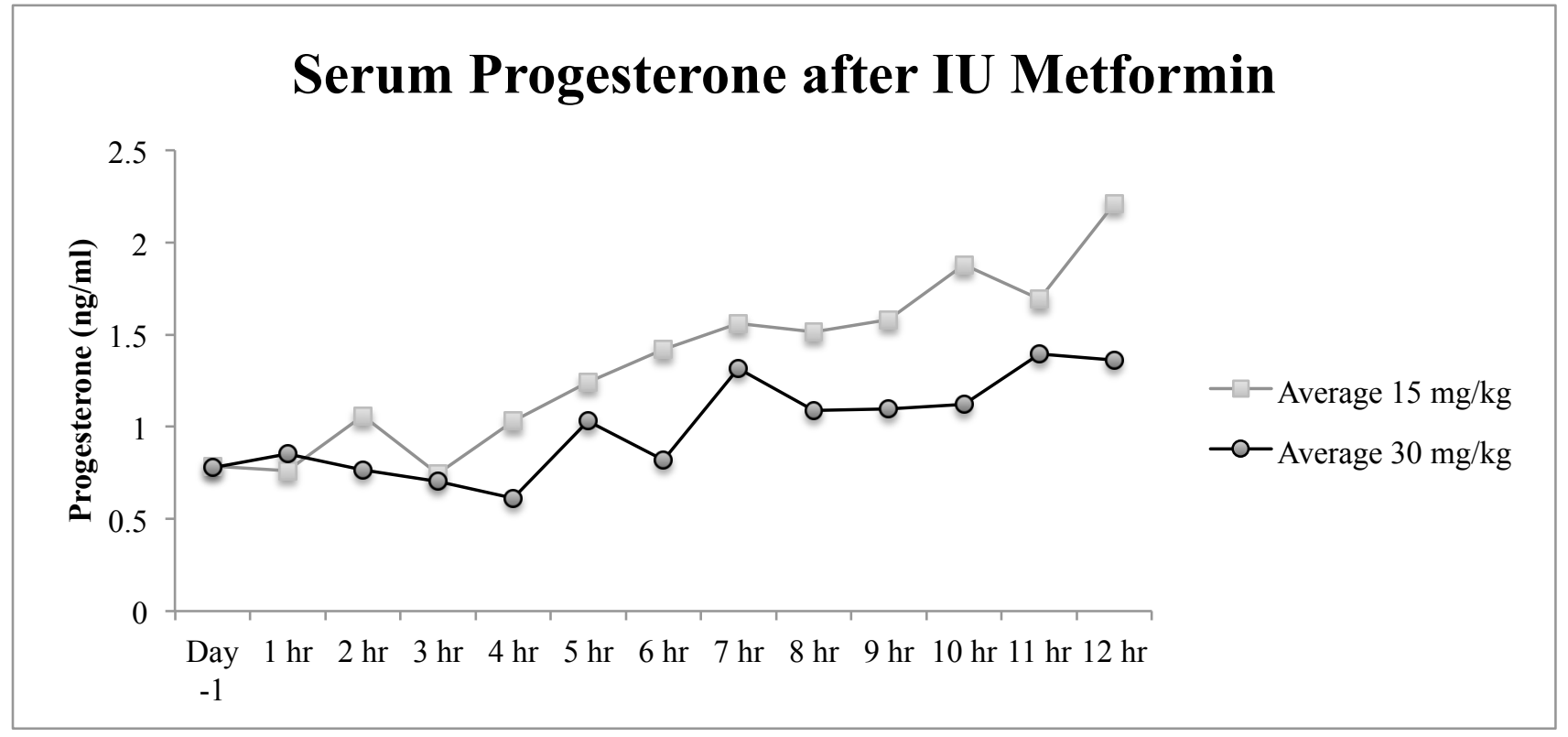

B

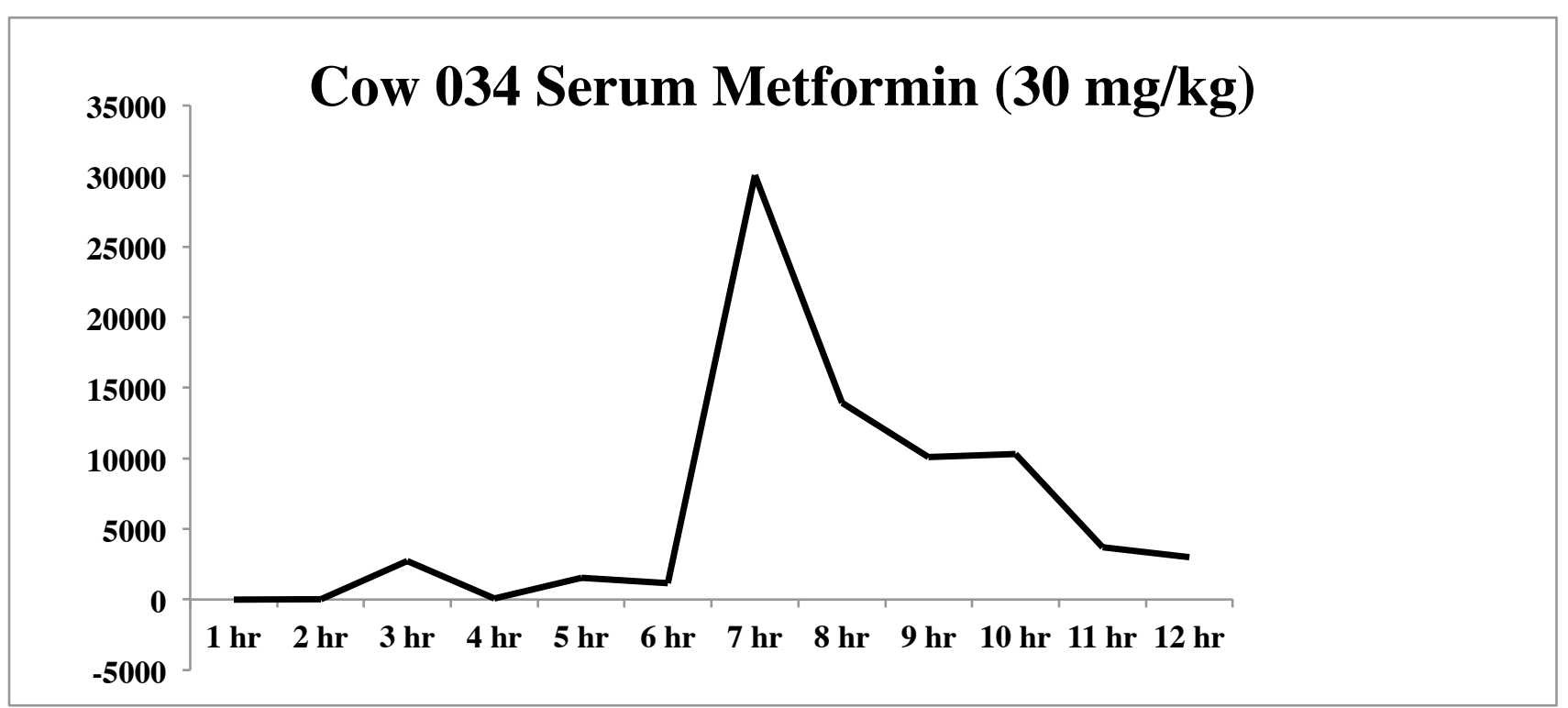

Figure 1.3: A-Serum progesterone values for 15 or $30(\mathrm{mg} / \mathrm{kg}$ of bw) IU of metformin. Serum progesterone was significantly lower 12 hours after starting treatment $(P<0.001)$ when cows received $30 \mathrm{mg} / \mathrm{kg}$ bw than when cows received $15 \mathrm{mg} / \mathrm{kg}$ bw. B-Representative HPLC graph of metformin concentrations in a cow receiving $30 / \mathrm{mg} \mathrm{kg}$ of bw. 


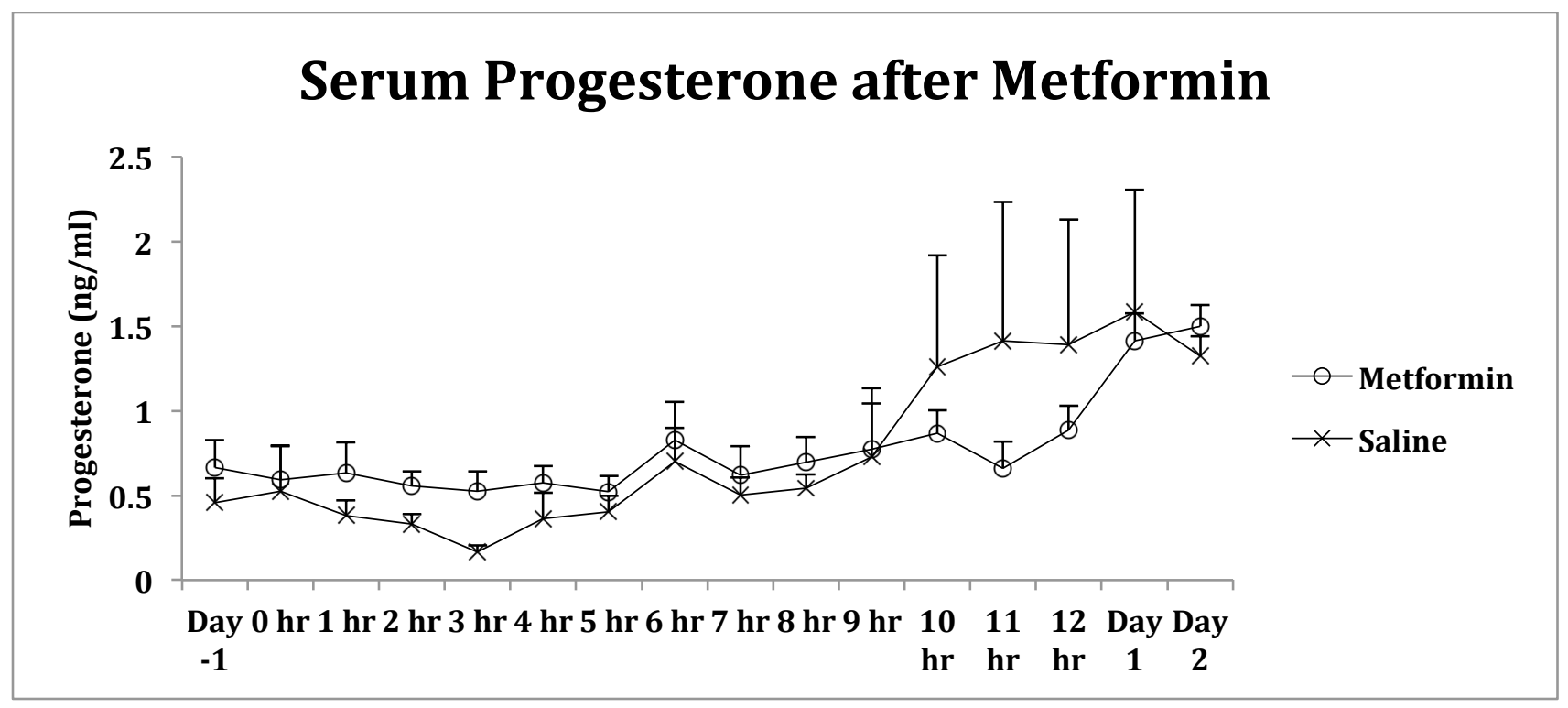

Figure 1.4: Serum progesterone concentrations pooled across all experiments showed that there was no difference in metformin-treated $(n=7)$ versus saline-control $(n=7)$ cows. 


\section{Serum Insulin Concentrations}

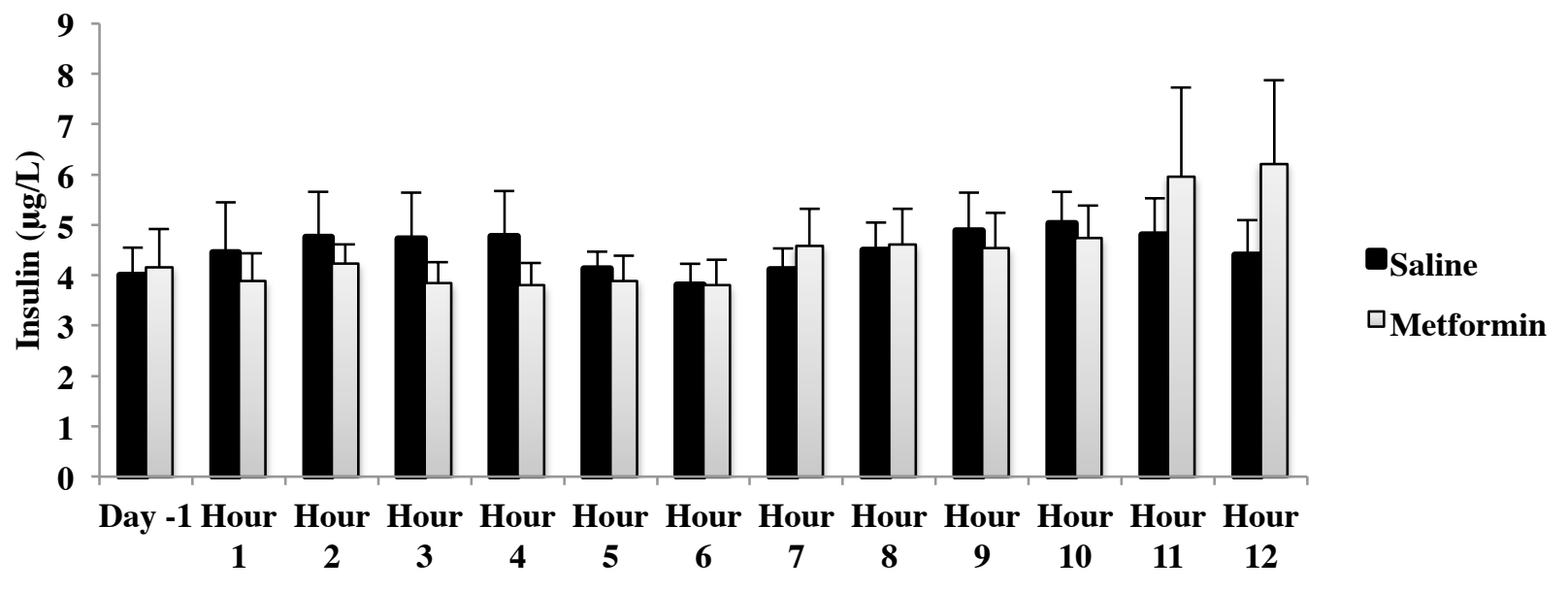

Figure 1.5: Serum insulin concentrations one day prior to and during metformin treatment. Cows were given $30 \mathrm{mg} / \mathrm{kg}$ bw of metformin IV or sterile saline for control cows every 3 hours over 12 hours, during the day of treatment. No significant difference of treatment or time was seen in insulin concentrations. 


\section{Chapter 3: Adenosine monophosphate activated protein kinase activation in vitro modulated progesterone secretion in mature but not developing bovine CL}

\section{Introduction}

The mechanisms governing the action of prostaglandin $\mathrm{F} 2$ alpha $\left(\mathrm{PGF}_{2} \alpha\right)$, are incompletely known. Nevertheless, this mechanism involves activation of the phospholipase C$\mathrm{Ca}^{2+}$ pathway (Davis et al., 1987). In luteal cells, $\mathrm{PGF}_{2 \alpha}$ has affects by binding to its cognate $\mathrm{G}_{\mathrm{q}}$ protein-coupled receptor and activating phospholipase C (PLC; Davis et al., 1988). The PLC cleaves plasma membrane-bound phosphatidylinositol 4,5-bisphosphate $\left(\mathrm{PIP}_{2}\right)$ to generate free IP3 (Berridge et al., 1983) and membrane-bound 1,2-diacylglycerol (DAG; Berridge, 1987), which increases $\mathrm{Ca}^{2+}$ and activates protein kinase $\mathrm{C}(\mathrm{PKC})$, respectively. Increases in both concentrations of cytoplasmic $\mathrm{Ca}^{2+}$ and activation of $\mathrm{PKC}$ have been demonstrated to mediate intracellular actions of $\mathrm{PGF}_{2 \alpha}$ in luteal cells (Wiltbank et al., 1990). Differential expression of genes associated with $\mathrm{Ca}^{2+}$ homeostasis plays a role in the development of luteolytic capacity of bovine CL. Greater concentrations of $\mathrm{PGF}_{2 \alpha}$ are needed to elicit $\mathrm{Ca}^{2+}$ responses in steroidogenic cells isolated from developing than from mature CL (Choudary et al., 2005). Additionally, gene expression of CAMKK2, a down-stream target of $\mathrm{Ca}^{2+}$, is increased in mature CL

(Goravanahally et al., 2009). The serine/threonine protein kinase CAMKK2 has been reported to mediate the action of intracellular $\mathrm{Ca}^{2+}$ via phosphorylation of calcium/calmodulin-dependent kinases (CAMKs). Whether CAMKK2 affects steroidogenesis or rather acts upon another intermediary to mediate its effects is not known. One target of CAMKK2 is adenosine monophosphate activated protein kinase AMPK (Wong, 2009). The kinase CAMKK2 phosphorylates AMPK, but this particular component of this signal transduction pathway has not 
been investigated in the bovine CL.

In multiple cell types, AMPK is an important regulatory protein for energy balance. In all eukaryotic cells it is a heterotrimeric complex composed of one catalytic subunit $\alpha$ (with two isoforms: PRKAA1 and PRKAA2) and two regulatory subunits $\beta$ (with two isoforms: PRKAB1 and PRKAB2) and $\gamma$ (with three isoforms: PRKAG1, PRKAG2, and PRKG3; Wong et al., 2009). Increases in cytoplasmic $\mathrm{Ca}^{+2}$ lead to activation of CAMKK2, which is capable of phosphorylating AMPK at $\mathrm{Thr}^{172}$. Binding of AMP to the $\gamma$ subunit activates AMPK by inducing conformational changes in the complex that promote phosphorylation of $\mathrm{Thr}^{172}$. Typically, activation of AMPK results in a shift from anabolic processes (Hardie, 2008), such as synthesis of proteins that are required for progesterone ( $\mathrm{P} 4)$ production, to catabolic processes. Recently, activated AMPK decreased P4 secretion in murine, bovine, and primary F1 galline granulosal cells (Tosca et al., 2005; Tosca et al., 2006; Tosca et al., 2007). All subunits of AMPK and their isoforms were present in whole ovaries, CL, small and large follicles as well as granulosal cells in the cow (Tosca et al., 2007). AMPK is activated in response to the antidiabetic drug metformin (Viollet et al., 2012), and by 5-Aminoimidazole-4-carboxamide-1- $\beta$ 4-ribofuranoside (AICAR), a cell-permeable allosteric AMPK activator (Corton et al., 1995). Dorsomorphin dihydrochloride (DM) is a potent, selective, cell-permeable and reversible AMPK inhibitor (Liu et al., 2014). It inhibited AMPK induced either by AICAR (Tang et al., 2011) or metformin (Isakovic et al., 2007). If CAMKK2 targets AMPK in bovine CL, increased gene expression of CAMKK2 during this developmental stage may lead to increased AMPK activation, and, therefore, become an additional mechanism to mediate effects of $\mathrm{PGF}_{2 \alpha}$.

The goal of this project was to investigate alternative downstream components activated by the rise in cytosolic $\left[\mathrm{Ca}^{2+}\right]$ initiated when the FP receptor is activated in bovine luteal tissue. 
The objectives of this research were to determine the changes in P4 secretion in the presence of AMPK activators or inhibitor in developing and mature bovine CL in vitro. Developmental differences in components of signal transduction associated with AMPK activation in developing and mature CL may explain, at least in part, the developmental differences in the ability of $\mathrm{PGF}_{2 \alpha}$ to induce functional luteal regression.

\section{Materials and Methods}

\section{Animal Handling and Surgical Procedures}

Non-lactating beef cows were observed twice daily for estrus at approximately $12 \mathrm{~h}$ intervals for 30 min per observation. The day when standing estrus was observed was designated as day 0 (d0). The West Virginia University Animal Care and Use Committee reviewed and approved the protocol for the tissue collection (ACUC \# 01-0809). Ovaries ( $d 4$; $n=5$ ) or CL ( $110 ; n=5$ ) were collected via supravaginal incision under epidural anesthesia (Casida, 1959) and transported in ice-cold saline to the laboratory. Connective tissue was removed prior to obtaining weights and slicing for treatment.

\section{Luteal Slice Incubation Procedure}

Luteal slices were incubated for 30 min with $500 \mu 1$ of minimum essential media (MEM, Life Technologies, Grand Island, NY) and pharmaceutical agents before hormones were added. Media were removed, and fresh media added back along with treatments for $2 \mathrm{hr}$ incubation at $37^{\circ} \mathrm{C}$, shaking at $200 \mathrm{rpm}$. Progesterone was assayed by radioimmunoassay (RIA) as previously described (Sheffel et al., 1982).

\section{Experiment 1}

Luteal slices were treated with MEM (control), $\mathrm{PGF}_{2} \alpha(1.0 \mu \mathrm{g} / \mathrm{ml}), \mathrm{DM}(10.9 \mu \mathrm{M} / \mathrm{L}$, Tocris, Bristol, UK), or DM $(10.9 \mu \mathrm{M} / \mathrm{L})$ and $\mathrm{PGF}_{2 \alpha}(1.0 \mu \mathrm{g} / \mathrm{ml})$. Media were collected and frozen at - 
$20^{\circ} \mathrm{C}$ until assayed for P4.

\section{Experiment 2}

Luteal slices were treated with MEM (control), $\mathrm{PGF}_{2 \alpha}\left(\mathrm{PGF}_{2} \alpha, 1.0 \mu \mathrm{g} / \mathrm{ml}\right)$, metformin (Met; 10, 5, 1, 0.5, 0.1 mM; New England Mail Order Pharmacy, Middlebury, VT), or AICAR (7.5, 0.75, $0.075 \mathrm{mM}$, Tocris, Bristol, UK). After incubation, slices were homogenized using an Omni Tissue Homogenizer (Omni International, Kennesaw, GA) in incubation media and frozen at $20^{\circ} \mathrm{C}$ until assayed for $\mathrm{P} 4$.

\section{Statistical Analysis}

Progesterone values were analyzed using ANOVA followed by Dunnett's Method for means comparisons to control. T-Test was used to compare the value of progesterone at the highest dose of metformin and AICAR with control values in both D4 and D10. Data were analyzed using JMP and SAS software (JMP®, Version Pro 11, SAS Institute Inc., Cary, NC, Copyright @2013; SAS®, Version 9.3, SAS Institute Inc., Cary, NC, Copyright @2002-2010). Significance criterion alpha for all tests was 0.05. Data are depicted as the mean \pm SEM.

\section{Results}

\section{Experiment 1}

No significant effects of PGF2 $\alpha(0.94 \pm 0.13 ; P=0.96), \mathrm{DM}(1.921 \pm 1.3, P=0.39)$, or $\mathrm{PGF}_{2 \alpha}$ and DM $(1.11 \pm 0.53 ; P=0.91)$ were observed on $\mathrm{P} 4$ production when compared to basal values $(1.00 \pm 0)$ in $\mathrm{d} 4 \mathrm{CL}$. In $\mathrm{d} 10 \mathrm{CL}, \mathrm{PGF}_{2 \alpha}$ increased $\mathrm{P} 4$ production $(2.4 \pm 0.35$ vs $1.00 \pm 0 ; P=$ $0.0003)$, while DM treatment alone $(1.34 \pm 0.11$ vs. $1.00 \pm 0)$ had no effect $(P=0.24)$. Stimulatory effect of $\mathrm{PGF}_{2 \alpha}$ was eliminated when DM was added, such that $\mathrm{P} 4$ values did not differ from controls $(1.85 \pm 0.54$ vs $1.00 \pm 0 ; P=0.31)$ but were different from PGF $_{2 \alpha}$ alone $(1.34 \pm 0.11$ vs $2.421 \pm 0.35 ; P=0.0037)$. 


\section{Experiment 2}

No significant effect of metformin $(P=0.91)$ or $\operatorname{AICAR}(P=0.51)$ at any concentration was observed in D4 CL. A decrease in basal P4 was observed with both metformin $(0.39 \pm 0.20 ; 10$ $\mathrm{mM} ; P=0.006)$ and AICAR $(0.40 \pm 0.15 ; 7.5 \mathrm{mM} ; P=0.0117)$ in D10 CL when compared to control $(0.99 \pm 0.32)$.

\section{Discussion}

These results indicate that AMPK is involved in the signal transduction mechanism of the mature but not developing bovine CL. No significant changes were observed in $\mathrm{P} 4$ production when d4 luteal tissue was treated with DM, metformin, or AICAR. However, d10 CL responded to all AMPK activators with a significant inhibition in P4 production, and the AMPK inhibitor eliminated this effect. All subunits of AMPK are present in the bovine ovary (Tosca et al., 2007), but gene expression of these subunits might change throughout development of the CL. In fact, Goravanahally (unpublished results) demonstrated that, with the exception of AMPK $\gamma 1$ and AMPK $\gamma 2$, mRNA expression of AMPK subunits were increased in the mature CL

$(P<0.05)$. Moreover, an additional observation supporting the interpretation that the effects of increases in cytosolic calcium are conveyed via CAMKK2-AMPK was that a CAMKK2 inhibitor, STO-609, blocked the inhibitory effects of $\mathrm{PGF}_{2 \alpha}$ in dispersed mature bovine luteal cells (Goravanahally, unpublished results). STO-609 also inhibited PGF $_{2 \alpha}$-induced phosphorylated state of AMPK (P-AMPK) in mature but not developing bovine CL. Collectively, these data demonstrate that the signal transduction pathway involving CAMKK2 and AMPK regulates luteal function in the mature, but not the developing CL.

Tosca et al. $(2005,2006,2007)$ have provided evidence in the rat, hen, and cow that 
AMPK is involved in steroid production in granulosal cells. It is not surprising that AMPK plays a role in steroidogenesis of luteal cells, as this population is derived from granulosal cells. In agreement with previous results, these data reveal that metformin and AICAR decreased basal P4 production. The effects of DM were developmentally different; DM had no effect on P4 production in developing $\mathrm{CL}$, but blocked the stimulatory effects of $\mathrm{PGF}_{2 \alpha}$ in mature CL. However, lower doses of metformin $(5,1,0.5,0.1 \mathrm{mM})$ or AICAR $(0.75,0.075 \mathrm{mM})$ did not affect P4 production. Doses of both AMPK activators were based on previous reports, in which a significant decline in basal P4 production was seen in vitro (Tosca et al., 2005; Tosca et al., 2007). However, CL tissue from this study was incubated for 2 hours before collection, compared to the range of 3 to 48 hours in the previous study with bovine granulosal cells (Tosca et al., 2007). Differences in P4 were significant at 2 hours of incubation, but longer incubation times with lower doses may have decreased steroid production.

In conclusion, DM eliminated the effect of $\mathrm{PGF}_{2 \alpha}$ on mature but not developing bovine CL. Higher doses of metformin and AICAR were capable of decreasing P4 in mature but not in developing bovine CL. This developmental difference in signal transduction may play a significant role in the ability of mature CL to regress in response to a single luteolytic dose of $\mathrm{PGF}_{2 \alpha}$. 
A

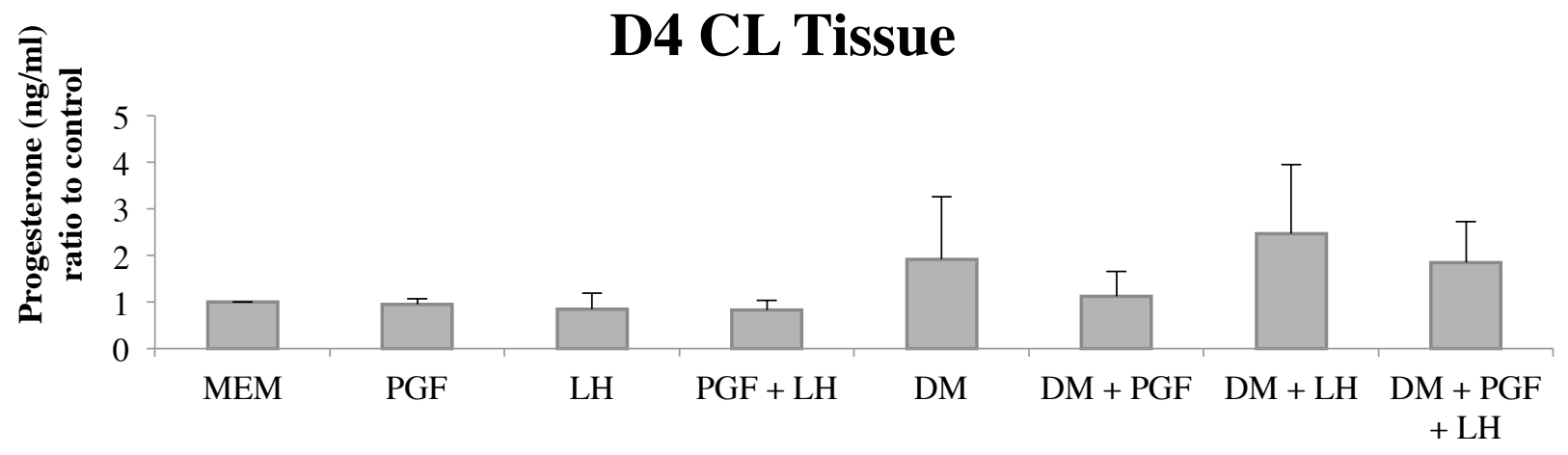

B

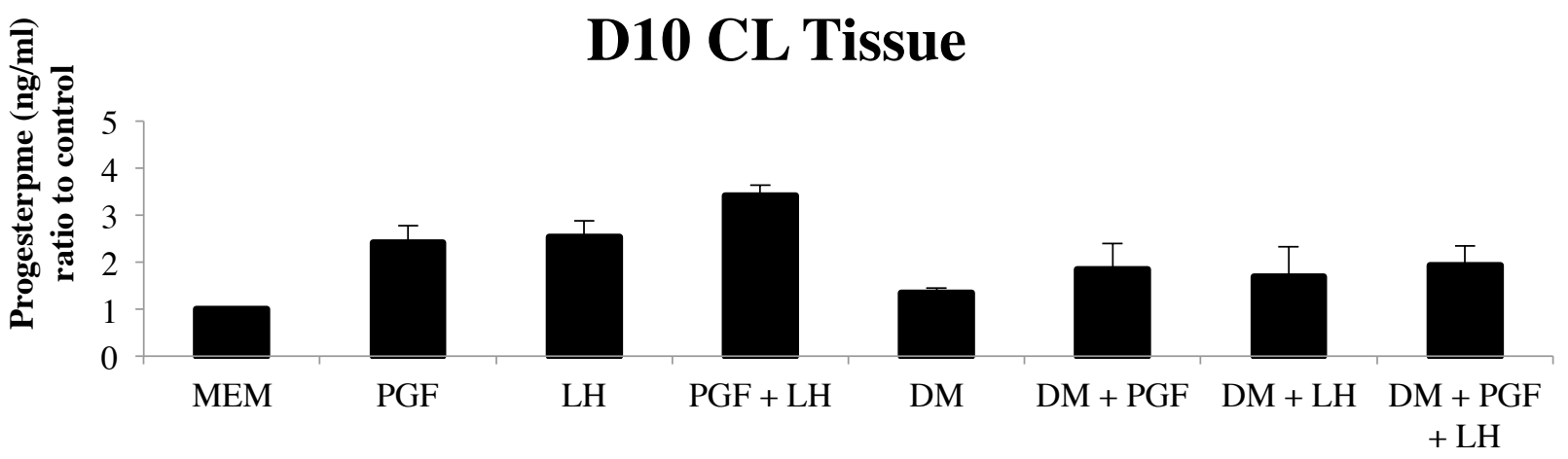

C

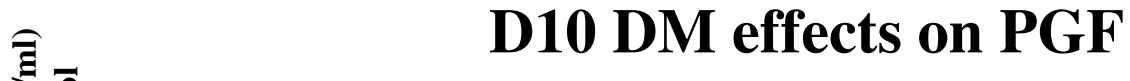

Figure 2.1-DM reduced the stimulatory effect of $\mathrm{PGF}_{2 \alpha}$ on $\mathrm{P} 4$ secretion in mature (D10) but neither $\mathrm{PGF}_{2 \alpha}$ nor DM alone or in combination with $\mathrm{PGF}_{2 \alpha}$ or $\mathrm{LH}$ were affected in the developing CL (D4). Luteal slices were incubated for 30 minutes in MEM and DM without hormones after which all media were removed, and fresh MEM, DM and hormones were added back. Media were collected and frozen until analyzed for progesterone with RIA. Different letters indicate significant differences at $(\mathrm{P}<0.05)$. 
A

\section{Day 4 CL}

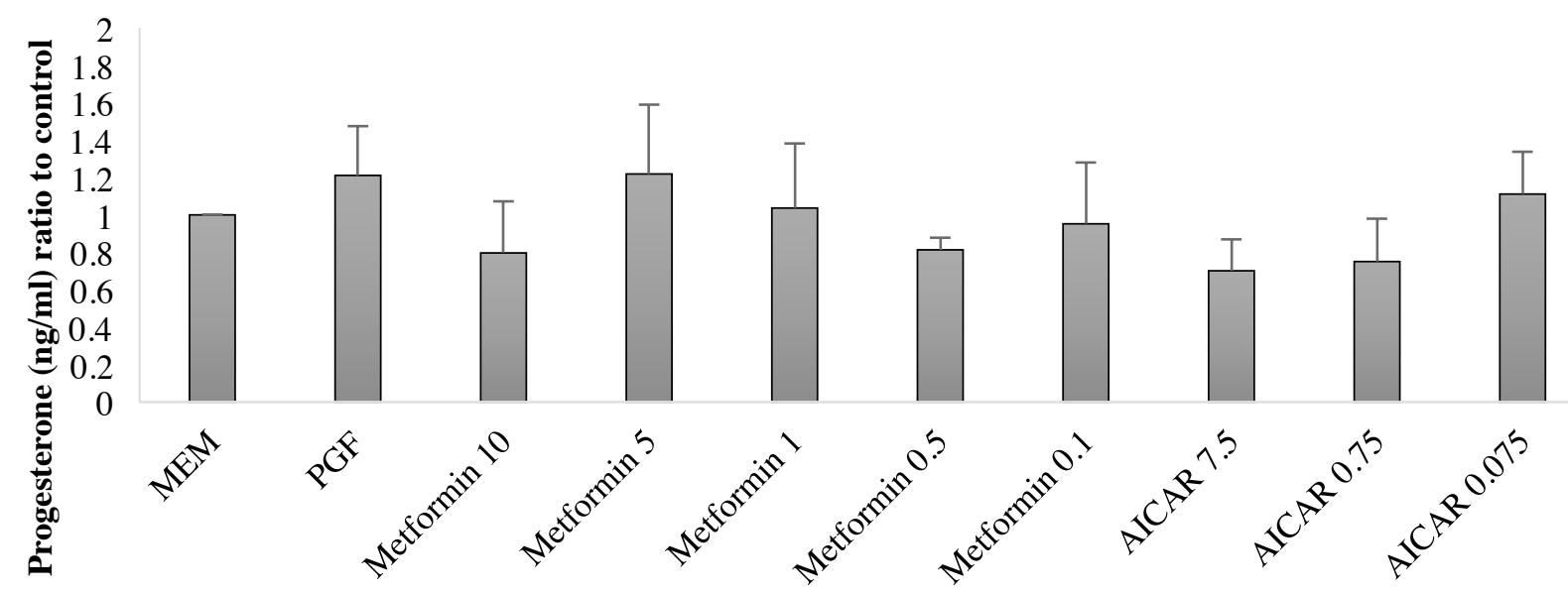

B

\section{Metformin and AICAR effects in D4 CL}

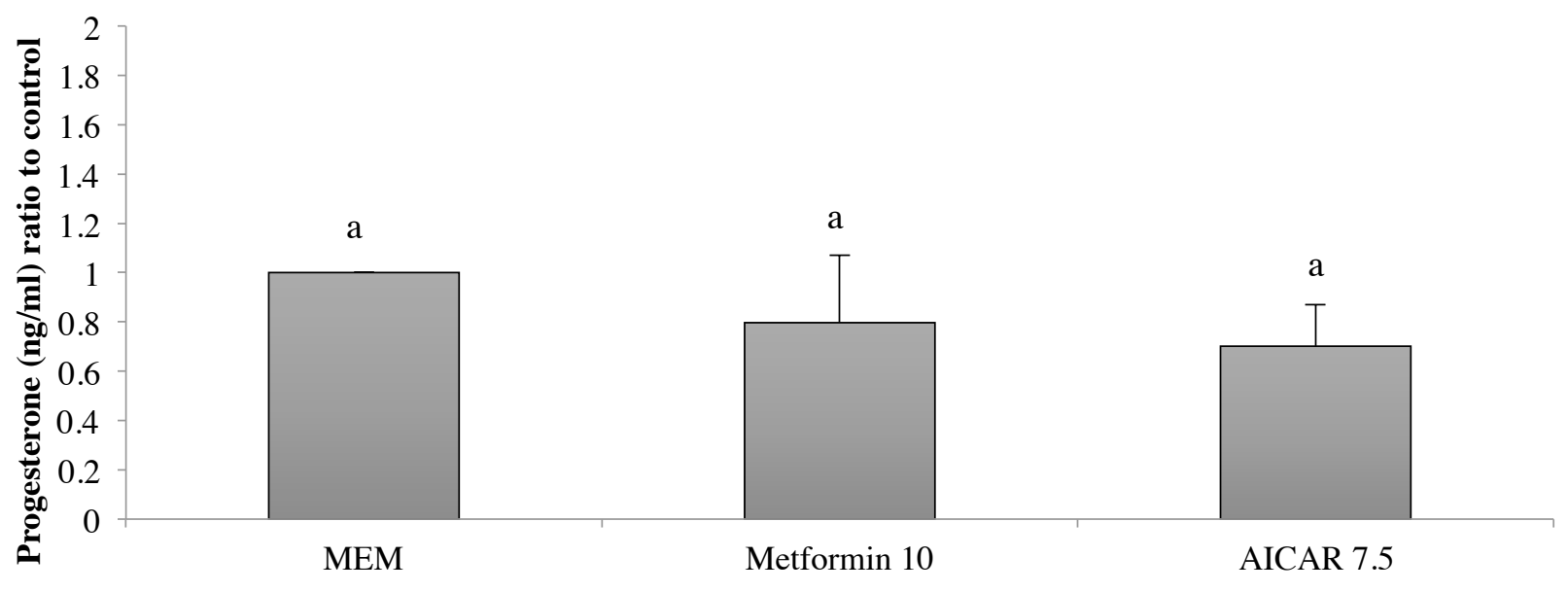

Figure 2.2: Neither $\mathrm{PGF}_{2 \alpha}$ nor its activators, metformin and AICAR, had any significant effect on basal progesterone production in developing (D4) bovine CL. Luteal slices were incubated for 30 minutes in MEM and metformin or AICAR without hormones after which all media were removed, and fresh MEM, metformin or AICAR and hormones were added back. Slices were homogenized in the media and then collected and frozen until analyzed for progesterone with RIA. Different letters indicate significant differences at $(\mathrm{P}<0.05)$. 


\section{Day 10 CL}

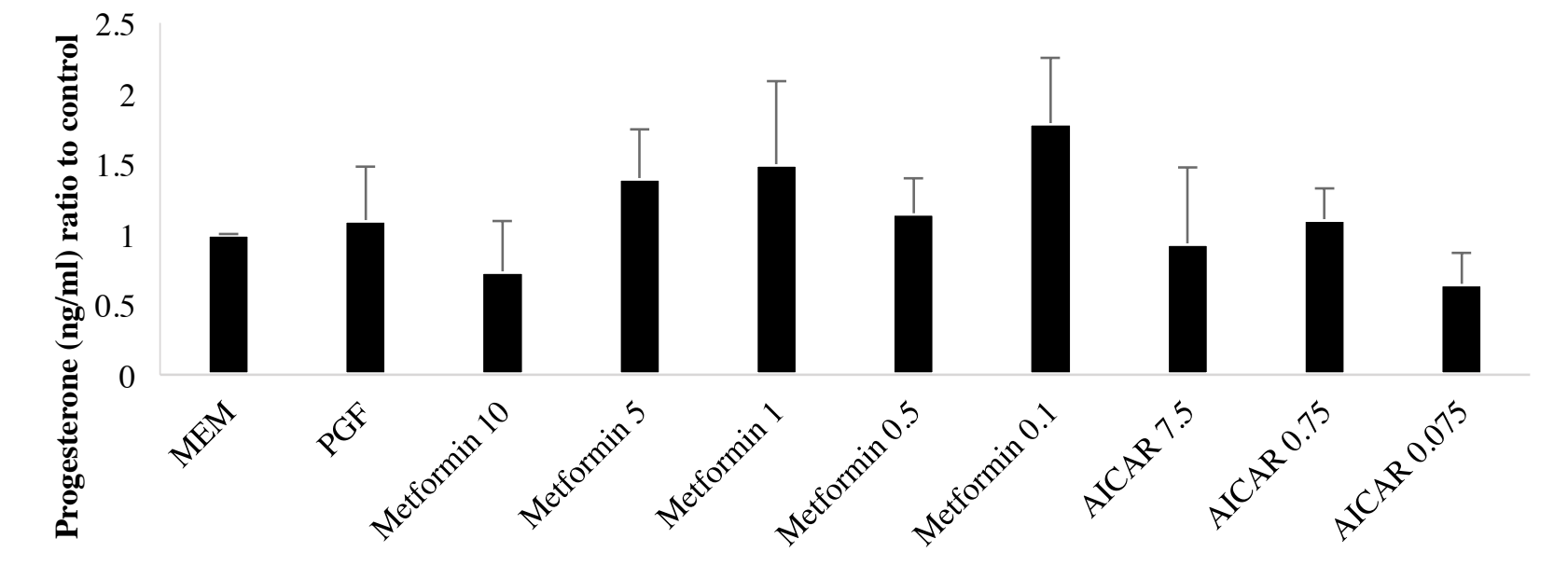

B

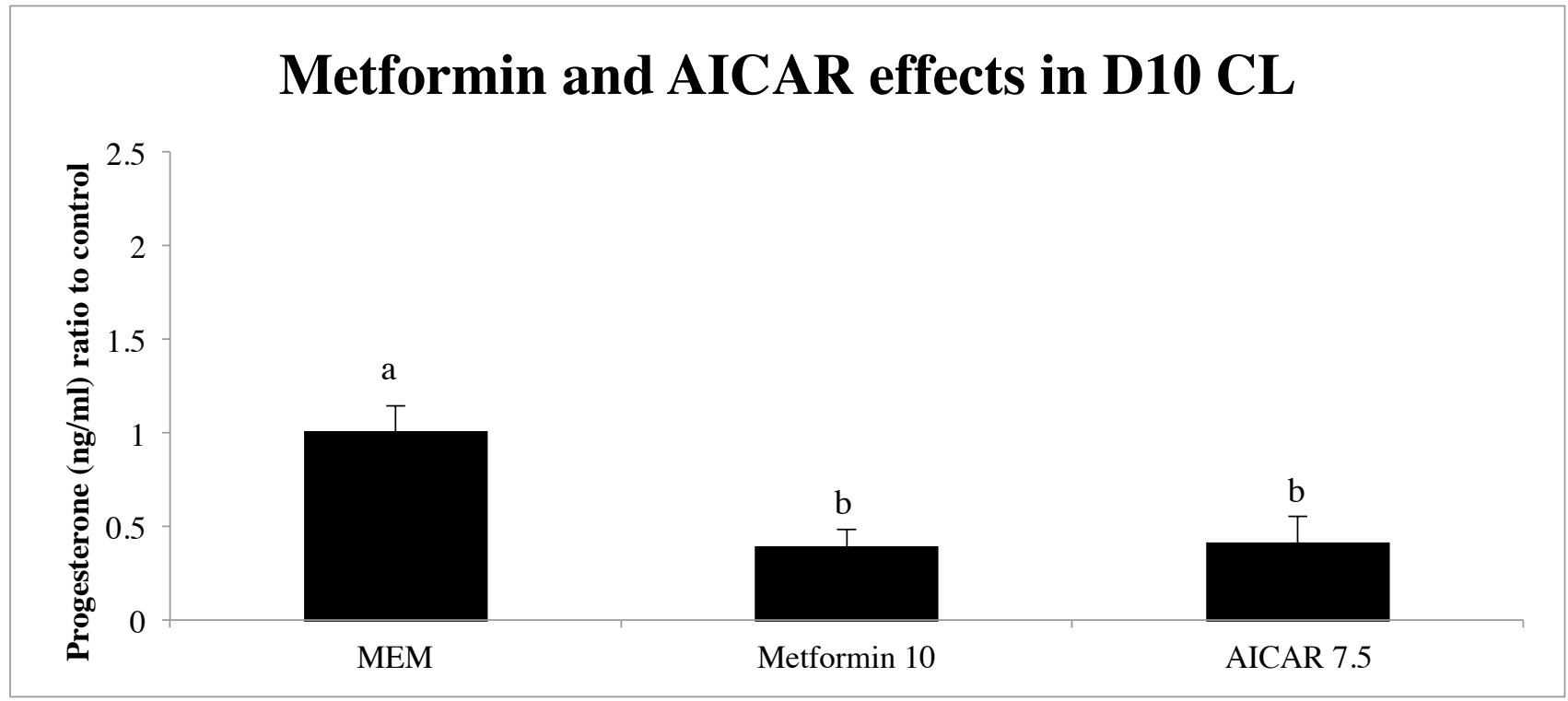

Figure 2.3: At the greatest concentrations tested, both metformin and AICAR significantly $(\mathrm{P}<$ 0.05) decreased basal progesterone production in mature (D10) bovine CL. Luteal slices were incubated for 30 minutes in MEM and metformin or AICAR without hormones after which all media were removed, and fresh MEM, metformin or AICAR and hormones were added back. Slices were homogenized in the media and then collected and frozen until analyzed for progesterone with RIA. Different letters indicate significant differences at $(\mathrm{P}<0.05)$. 


\section{Chapter 4: Primary infertility affects progesterone production by luteinized human mural granulosal cells in vitro}

\section{Introduction}

Follicles, comprised of the oocyte, granulosal and thecal cells, are the functional unit of the ovary. The somatic cells in the outermost vascular portion of the follicle include thecal and myoepithelial cells. The avascular component of the follicle is delimited by a basement membrane upon which the other somatic cells of the follicle, the granulosal epithelial layer and the germ cell reside. Two populations of granulosal cells have been identified: mural and cumulus granulosal cells. Both populations of cells are organized as a stratified epithelium with the basal layer of mural cells contacting the basement membrane adjacent to the thecal cells and the cumulus cells surrounding the oocyte (Buccione et al., 1990). Mural granulosal cells express receptors for FSH and LH as well as the enzymes 3 $\beta$-HSD and P450scc (Zoller and Weisz, 1979). Expression of these two enzymes is representative of a luteal characteristic in these cells, while cumulus granulosal cells remain with the oocyte even after ovulation (Russell and Salustri, 2006). Once ovulation has occurred, mural granulosal cells lose their ability to proliferate, undergo epithelial-mesenchymal transition and differentiate into large luteal cells (LLC) of the corpus luteum (CL), which secrete high amounts of basal progesterone (P4; Chaffkin et al., 1992). Interestingly, $\mathrm{P}_{4}$ receptors (PGR) cannot be detected with immunohistochemical analysis in human granulosal cells at any follicular stage but they are detected readily in human luteal tissue (Suzuki et al., 1994). The fact that PGR is absent in preovulatory follicles but present in periovulatory follicles and in the CL after a surge of gonadotropins supports the hypothesis that LH induces PGR expression (Hild-Petito et al., 1988). Thecal cells become small luteal cells (SLC) once luteinization has occurred. 
In the CL of primates, granulosal and thecal cells remain as two distinct populations and are separated by the remnants of the follicular basement membrane (Guraya, 1971). In contrast, the basement membrane separating these two cell populations is remodeled, and thecal cells, which become SLC, invade the granulosal cells to form a heterogeneous mixture of cells in the CL of nonprimate species (Niswender, 2000). Rescue of the CL during the fertile cycle by human chorionic gonadotropin (hCG) is essential for maintenance of pregnancy once the oocyte is fertilized. Infertility is a problem that affects millions of women and their partners across the United States. Causes of infertility range from ovulatory dysfunction to male related infertility due to abnormal sperm motility or morphology. Insufficient luteal rescue can account for pregnancy loss in couples conceiving naturally as well as those that have undergone time consuming and expensive procedures such as intrauterine insemination or in vitro embryo production.

Human granulosal cells that have been recovered during oocyte retrieval in patients undergoing in vitro fertilization spontaneously luteinize in culture, thus these cells have been used as a model to study granulosal-lutein cells of the CL (Stewart and Vandevoort, 1997). The degree of luteinization of these cells has not been clearly defined, and studies using them do not take into account the heterogeneity of a granulosal cell population or the fertility status of the patient from whom they were isolated. Using patient cause of infertility as an experimental variable offers a unique opportunity to study how infertility affects P4 production by luteinized granulosal cells when subjected to hormonal treatments.

In multiple species, $\mathrm{PGF}_{2 \alpha}$ elicits both inhibitory and stimulatory $\mathrm{P} 4$ responses in luteal cells in vitro. Most investigators use a non-physiological dose of $\mathrm{PGF}_{2 \alpha}$ when treating luteal cells in vitro. The fact that $\mathrm{PGF}_{2 \alpha}$ at high concentrations is able to activate the $\mathrm{PGE}_{2}$ receptor 
could, in part, explain increases in P4 production (Rao, 1974). Additionally, the entire population of cells that would normally be present in addition to luteinized granulosal cells is not present in all in vitro experiments. Inhibitory action of $\mathrm{PGF}_{2 \alpha}$ on human luteinized granulosal cells may be enhanced by presence of endothelial and/or immune cell types (Liptak et al., 2005).

In multiple cell types, AMPK is an important regulatory protein for energy balance. Typically, activation of AMPK results in a shift from anabolic processes (Hardie, 2008), such as synthesis of proteins that are required for progesterone production, to catabolic processes. The antidiabetic drug metformin activates AMPK (Viollet et al., 2012), and by 5-Aminoimidazole-4carboxamide-1- $\beta$-4-ribofuranoside (AICAR), a cell-permeable allosteric AMPK activator (Corton et al., 1995). Dorsomorphin dihydrochloride (DM) is a potent, selective, cell-permeable and reversible AMPK inhibitor (Liu et al., 2014), and DM inhibited AMPK induced either by AICAR (Tang et al., 2011) or metformin (Isakovic et al., 2007). Metformin is the most widely used drug for the treatment of type II diabetes, being prescribed to nearly 120 million people worldwide (Viollet et al., 2012). Recently, metformin was used to treat women experiencing PCOS who were overweight or insulin resistant. Metformin's ability to increase insulin sensitivity in individuals made it an ideal candidate for the treatment of PCOS. Metformin increased insulin sensitivity in patients with PCOS, and it increased ovulation rate, improved menstrual cyclicity, and reduced serum androgen (Tang et al., 2010). Metformin appears to work in PCOS patients by both direct ovarian effects and secondarily through decreasing insulin resistance. In bovine granulosal cells isolated from small antral follicles metformin has been shown to have effects on steroidogenesis (Tosca et al., 2007). Metformin (10 mM) reduced both progesterone and estradiol production as well as key enzymes (HSD3 $\beta$, CYP11A1, and STAR) with or without FSH and/or IGF1 in the media (Tosca et al. 2007). 
The goal of this project was to investigate the use of human mural granulosal and cumulus cells to study potential downstream targets activated by the known intracellular mediators, $\mathrm{AMPK}$ and $\mathrm{Ca}^{+2}$, of luteolytic actions of $\mathrm{PGF}_{2 \alpha}$ actions in bovine luteal cells. Additionally, it was hypothesized that P4 stimulatory and inhibitory responses to hCG and $\mathrm{PGF}_{2 \alpha}$, respectively, would differ among infertility types. The objectives of this research were to define culture conditions and responses of luteinized human granulosal cells derived from patients with various infertility causes to luteotropic and luteolytic signals and to determine effects of increasing intracellular $\mathrm{Ca}^{+2}$ from low to high values on $\mathrm{P} 4$ production. The proposed research had one central hypothesis: luteinized mural granulosal cells can be used to study how infertility influences luteal efficiency and the effects of increasing intracellular $\mathrm{Ca}^{+2}$ on $\mathrm{P} 4$ production in order to determine if providing the known intracellular mediator of the best known luteolytic factor, $\mathrm{PGF}_{2 \alpha}$, could directly induce a reduction of $\mathrm{P} 4$, which is the hallmark event underlying luteal regression.

\section{Materials and Methods}

\section{Patients}

Mural and cumulus granulosal cells from patients affected by different causes of infertility were provided by the WVU Center for Reproductive Medicine in Morgantown, WV after patient's ovaries were stimulated for transvaginal oocyte collection for in vitro fertilization (IVF). Patients ranged in age from 25-40 years of age, had a BMI range of 18.9 to 44.3 , and presented with primary infertility types of male factor (male, $n=5$ ), endometriosis (endo, $n=6$ ), tubal factor (tub, $\mathrm{n}=12$ ), and unexplained/other (other, $\mathrm{n}=3$ ). Daily or twice daily injections of recombinant follicle stimulating hormone (FSH) began on $\mathrm{d} 2$ or $\mathrm{d} 3$ of the cycle and continued until ovulation was induced with hCG. Patients returned at least every other day for ultrasonic 
monitoring of follicular growth beginning four days after stimulation. To prevent premature ovulation, GnRH agonist injections began when follicles reached at least $14 \mathrm{~mm}$ in diameter. Ovulation was induced with hCG injection once follicles were $\geq 18 \mathrm{~mm}$ in diameter, followed by oocyte collection $34 \mathrm{~h}$ later.

\section{Isolation and culture of primary human GCs}

Follicular aspirates from each patient were centrifuged at 10,000 rpm for $5 \mathrm{~min}$ at room temperature. Supernatant was discarded, and the pellet was resuspended in $500 \mu 1$ of DMEM/F12 (Invitrogen, Grand Island, NY) with 20\% (v/v) fetal bovine serum, insulin/transferrin/selenium B (1000; 555; 0.67 mg/L respectively; Gibco, Grand Island, NY), gentamicin/amphotericin (10 $\mu \mathrm{g} / \mathrm{ml}-0.25 \mu \mathrm{g} / \mathrm{ml}$; Gibco, Grand Island, NY), and penicillin/streptomyocin (100 I.U./ml, $100 \mu \mathrm{g} / \mathrm{ml}$; Life Technologies, Grand Island, NY). Viable cell number was determined using trypan blue dye exclusion and hemocytometer. Cells were plated at 10,000 cells per well in 96-well flat bottom culture plates with $300 \mu \mathrm{LMEM} / \mathrm{F} 12$ media (NUNC, Scientific Laboratory Supplies, Wilford, Nottingham, UK) at $37^{\circ} \mathrm{C}$ and $5 \% \mathrm{CO}_{2}$ in a humidified incubator to permit luteinization and cell attachment. Media was changed every $24 \mathrm{~h}$ whereby $150 \mu \mathrm{l}$ of spent media was replaced with fresh DMEM/F12 with serum. Four days after collection, cells were transferred to serum free DMEM/F12 media, and treatments were administered. Every treatment was tested in triplicate for each patient and media pooled for P4 by radioimmunoassay (RIA) as previously described (Sheffel et al., 1982).

\section{Experiment 1}

Cells were treated with $\mathrm{PGF}_{2 \alpha}(0.1 \mu \mathrm{g} / \mathrm{ml})$, human hCG $(5 \mathrm{IU} / \mathrm{ml})$, or a combination of both $\mathrm{PGF}_{2 \alpha}$ and hCG. Cells were cultured further for $24 \mathrm{~h}$ after which medium was removed and frozen at $-20^{\circ} \mathrm{C}$ until assayed for P4. Primary cause of infertility (male factor, endometriosis, 
tubal factor, and unknown), age $(<30,30-35,36-40$ years of age), BMI (normal = 18.5-24.9, overweight $=25-29.9$, obese $>30$ ), and pregnancy outcome (non-pregnant, and pregnant) were examined separately due to the variability among patients in these categories.

\section{Experiment 2}

Cells were treated with an intracellular calcium buffer 1,2-bis (o-aminophenoxy) ethaneN,N,N',N'-tetraacetic acid, BAPTA $(500,50,5,0.5 \mu \mathrm{mol}$, Tocris, Bristol, UK) or a calcium ionophore A23187 (1, 0.1, 0.01, 0.001, 0.0001, 0.00001, $0.000001 \mu \mathrm{mol}$, Tocris, Bristol, UK) to determine effects of altering intracellular $\mathrm{Ca}^{+2}$ on $\mathrm{P} 4$ production in luteinized human granulosal cells. Treatment concentrations of BAPTA and A23187 and incubation times were based on previous studies with bovine luteal steroidogenic cells and preliminary studies testing 1,3 , and $24 \mathrm{~h}$ incubation times in mural granulosal cells, respectively. The medium for the control group contained $0.1 \%$ dimethylsufoxide (DMSO, Pierce Rockport, IL), the solvent used for BAPTA and A23187. Cells were treated with BAPTA or A23187 for 1 hour, and medium was removed and frozen at $-20^{\circ} \mathrm{C}$ until assayed for $\mathrm{P} 4$.

\section{Experiment 3}

Under the same culture conditions, mural granulosal cells were treated with DM $(109,10.9,1.09$, $0.109 \mu \mathrm{m} / \mathrm{L}$, Tocris, Bristol, UK) or $\operatorname{AICAR}(7.5,0.75,0.075,0.0075 \mathrm{mM}$, Tocris, Bristol, UK ) to evaluate the roles of inhibiting/stimulating AMPK, respectively, in luteinized mural granulosal cell $\mathrm{P} 4$ production. Cells were cultured for further $24 \mathrm{~h}$ and medium was removed and frozen at $-20^{\circ} \mathrm{C}$ until assayed for $\mathrm{P} 4$

\section{Experiment 4}

Due to stimulation of $\mathrm{P} 4$ that was observed when cells were treated with $\mathrm{PGF}_{2 \alpha}$ it was hypothesized that this increase was due to promiscuous binding to another PG receptor, such as 
$\mathrm{PGE}_{2}$, which is known to increase $\mathrm{P} 4$. To test this hypothesis, mural granulosal cells were cultured with media alone (control), $\mathrm{PGF}_{2 \alpha}, \mathrm{PGF}_{2 \alpha}$ antagonist (AL 8810; $1.0 \mu \mathrm{mol}$, Cayman Chemical, Ann Arbor, MI), and $\mathrm{PGF}_{2 \alpha}$ and AL 8810. Preliminary dose response studies for AL 8810 at 10, 1, and $0.1 \mu \mathrm{mol}$ were conducted in order to find an optimum dose for experiment 4. The medium for the control group contained $0.1 \%$ dimethylsufoxide (DMSO; Pierce, Rockport, IL), the solvent used for AL 8810. Cells were preincubated with AL 8810 for 30 min, treatments were administered and cells cultured for 24 hours. Medium was collected and frozen at $-20^{\circ} \mathrm{C}$ until assayed for $\mathrm{P} 4$. Additionally, the effect of $\mathrm{PGF}_{2 \alpha}$ and $\mathrm{hCG}$ on $\mathrm{P} 4$ production in cumulus cells was tested.

\section{Statistical Analysis}

Concentrations of P4 were tested for normal distribution via the Shapiro-Wilk test. All data were transformed using natural logarithm. The one-tailed Student $t$-test was used to examine P4 production in A23187 experiments. All other experiments were analyzed using ANOVA and Dunnett's post hoc test. Data were analyzed using JMP and SAS software (JMP ${ }^{\circledR}$, Version Pro 11, SAS Institute Inc., Cary, NC, Copyright $@$ C2013; SAS ${ }^{\circledR}$, Version 9.3, SAS Institute Inc., Cary, NC, Copyright (C2002-2010). Differences were considered significant when $P<0.05$. Data in all graphs are depicted as the mean \pm SEM.

\section{Results}

\section{Experiment 1}

There was an increase in P4 production in cells treated with $\mathrm{hCG}$ who had been collected from patients that presented with male infertility factor compared to control $(P=0.0045$; Figure 3.1-A), but not in patients who presented with tubal, endometriosis, or diminished ovarian reserve factor $(P>0.05$; Figure 3.1-B,C,D). No significant differences in $\mathrm{P} 4$ were seen when 
granulosal cells were treated with $\mathrm{PGF}_{2 \alpha}$ across all infertility types $(P>0.05)$. Additionally, hCG elicited a significant increase in P4 production in patients in the age range of 30-35 ( $\mathrm{n}=15$; $P=0.008)$ and $36-40(\mathrm{n}=6 ; P=0.04)$, but not in patients in the ranges of $25-30(\mathrm{n}=4 ; P=$ 0.73) (Figure 3.2). Patients with normal BMI $(18.5-24.9, \mathrm{n}=16)$ had a significant increase in P4 production when treated with hCG $(P<0.0001)$, but granulosal cells of patients who were categorized as overweight (BMI of 25-29.9, $\mathrm{n}=6$ ) or obese $(\mathrm{BMI}>30, \mathrm{n}=3$ ) did not have a significant increase in $\mathrm{P} 4$ production when stimulated with hCG $(P>0.05)$ (Figure 3.3). Figure 3.4 demonstrates that granulosal cells from patients who became pregnant to the IVF cycle had significantly greater P4 production when stimulated with hCG $(3.23 \mathrm{ng} / \mathrm{ml} ; P=0.0018$ vs. control) than those who did not become pregnant $(1.57 \mathrm{ng} / \mathrm{ml} ; P>0.05$ vs. control).

\section{Experiment 2}

A significant reduction in $\mathrm{P} 4$ production was found with all concentrations of AICAR except the lowest $(0.0075)$ when compared to control $(P<0.001)$. However, no difference was observed when cells were treated with DM at any concentration $(P>0.05)$.

\section{Experiment 3}

There was a trend $(P=0.062)$ for $\mathrm{PGF}_{2 \alpha}$ treatment to increase $\mathrm{P} 4$ production in mural granulosal cells (Figure 3.6-A). The $\mathrm{PGF}_{2 \alpha}$ receptor antagonist, AL 8810, did not block this stimulation. However, there was a signficant difference between controls and $\mathrm{PGF}_{2 \alpha}$ and AL 8810 in combination $(P=0.024)$. Cumulus cells responded to hCG stimulation with a signficant increase in $\mathrm{P} 4$ production $(P=0.045)$, but no difference in $\mathrm{P} 4$ was observed when cumulus cells were treated with $\mathrm{PGF}_{2 \alpha}$ or $\mathrm{PGF}_{2 \alpha}$ and the $\mathrm{PG}$ antagonist (Figure 3.6-B).

\section{Experiment 4}

Progesterone production was increased in mural granulosal cells by A23187 at $0.01 \mu \mathrm{mol}$ 
$(P=0.041)$, and a trend $(P=0.096)$ was observed at 0.1 and $1.0 \mu$ mol concentrations tested in comparison to control concentrations. There was a cubic trend for the effect of BAPTA concentration on $\mathrm{P} 4$ production $(P=0.093)$ in mural granulosal cells.

\section{Discussion}

Data from experiment 1 supported the conclusion that types of infertility affect the ability of luteinized mural granulosal cells to respond to the luteotropic factor, hCG, in vitro. Knowing the cause of a patient's infertility prior to cell culture experiments offers a unique model to study how infertility affects $\mathrm{P} 4$ production by luteinized granulosal cells subjected to hormonal treatments. Failure of these cells to respond to hCG in vivo could lead to luteal insufficiency or even early regression of the corpus luteum, resulting in pregnancy loss. Implementing different post-implantation hormonal treatments based on specific causes of infertility could lead to increased pregnancy rates while keeping the number of multiple gestations low.

Interestingly, mural cells of women who did not become pregnant had significantly lower $\mathrm{P} 4$ production when stimulated with $\mathrm{hCG}$, when compared to the mural cells of pregnant women. Failure of these cells to secrete high levels of $\mathrm{P} 4$ in vivo is similar to a condition known as luteal phase defect (LPD). In LPD is a brief elevation in P4 secretion (typically $<11$ days) after ovulation, and is reported to occur in up to 20 percent of women (Balasch and Vanrell, 1987). This short luteal phase may be due a defect in the process of luteinization or progesterone production. However, it was postulated by Strott et al. (1970) that luteal phase defect occurs as a result of low preovulatory FSH levels. This leads to abnormal follicular development and subsequent inadequate luteinization and/or luteal function. This condition occurs despite normal LH stimulation at the time of the ovulatory surge (Strott et al., 1970). This could be the case in the cells from patients who did not become pregnant, where inadequate FSH levels resulted in 
the mural granulosal cells being unable to respond to hCG. These experiments were performed four days after oocyte retrieval, which is later than when embryos are normally transferred at the WVU CRM. It would be interesting to stimulate cells sooner to determine if they could be used as a predicator of pregnancy success prior to embryo implantation. If these cells could be used as a diagnostic tool, it could save patients and embryologists substantial time and monetary resources.

It was not surprising that P4 production by mural granulosal cells was affected by patient age. The ability to conceive naturally, which decreases as women age; naturally decreases by $11 \%$ from $30-34$, and another $12 \%$ from ages $35-40$ (Leridon, 2004). Decreased fertility may be explained partially by luteal insufficiency. The fact that luteinized mural granulosal cells did not respond to hCG with increases in P4 leads to the implication that luteal cells derived from these follicles would not respond sufficiently. Surprisingly, the age group that did not have an increase in $\mathrm{P} 4$ production was the youngest age group. Types of primary infertility were represented well in this group, but the small population size $(n=4)$ may explain this anomaly. In contrast, it was encouraging to see that mural cells from older patients responded to luteotropic hCG.

Patients with BMIs in the overweight or obese range did not respond to hCG with increased P4 production. The interrelationship between nutritional status and reproduction is complicated, and the mechanisms connecting the two are not well defined. However, insulin, glucose, IGF-1, and leptin all impinge on follicular development directly or influence gonadotropins at the hypothalamic level. As BMI and adiposity increase so do leptin, and insulin resistance. It will be critical to ascertain if the mural cells of overweight and obese patients have insufficient substrate to produce $\mathrm{P} 4$ when stimulated or if they are resistant despite 
adequate substrate. Women with PCOS are often obese as well as insulin resistant, and are prescribed insulin-sensitizing medicines such as metformin (Tang et al., 2010).

Metformin works, in part, by activating AMPK, a key regulator of energy homeostasis that has direct effects on P4 production in bovine (Tosca et al., 2007), galline (Tosca et al., 2007) and rodent (Tosca et al., 2005) granulosal cells. Using another AMPK activator, AICAR, a significant decrease in $\mathrm{P} 4$ was seen at all concentrations tested. A decrease in $\mathrm{P} 4$ production has been shown in mature but not developing bovine CL, as mentioned earlier in this dissertation. This decrease in P4 could be explained by a decrease in key enzymes such as 3ßHSD, P450scc, or StAR, all of which decreased in rat granulosal cells (Tosca et al., 2005). In contrast, no difference in P4 production was seen when mural cells were treated with an AMPK inhibitor, DM. The concentrations of DM chosen for experiment 2 were based on studies in bovine CL, in which DM significantly decreased P4 production. Possibly, a greater concentration of DM was needed to elicit a change in P4 production in human mural granulosal cells.

A stimulatory effect of $\mathrm{PGF}_{2 \alpha}$ has been observed consistently over time and has been attributed by some to the use of non-physiological doses of $\mathrm{PGF}_{2 \alpha}$ in vitro, which activate other prostaglandin receptors (Rao et al., 1974). Progesterone stimulation was observed in mural granulosal cells but not in cumulus granulosal cells (Figure 6). A specific $\mathrm{PGF}_{2 \alpha}$ receptor antagonist was unable to eliminate this effect in mural cells, indicating that the stimulation of $\mathrm{P} 4$ production was mediated by another prostaglandin receptor. Possibly, $\mathrm{PGF}_{2 \alpha}$ is binding to $\mathrm{PGE}_{2}$ receptors and increasing cAMP, which leads to an increase in P4. The ability of cumulus cells to respond to hCG with an increased P4 indicates that, even after ovulation, $\mathrm{hCG}$ is capable of signaling the oocyte. Human cumulus oocyte complexes express LH receptors (LHR) and upregulate LHR expression during the ovulatory process even though LHR expression in cumulus 
cells is much lower than in mural granulosal cells (Jeppesen et al., 2012).

It is commonly accepted that increases in intracellular $\mathrm{Ca}^{+2}$ in response to $\mathrm{FP}$ activation cause a decrease in $\mathrm{P} 4$ production in luteal cells. A quadratic effect on P4 production was seen when the calcium buffering capacity of the cells was increased by BAPTA. Increases in intracellular $\mathrm{Ca}^{+2}$ were needed to support $\mathrm{P} 4$ production in bovine luteal cells (Alila et al., 1990). Concentrations of BAPTA at 5 and $50 \mu \mathrm{mol}$ were needed before a decrease in P4 production was observed in experiment 4 (Figure 7). A threshold of intracellular $\mathrm{Ca}^{+2}$, even beyond the highest concentration in experiment 4, may be needed to decrease P4 production. Lower concentrations of BAPTA had either no effect or stimulated P4 production (Figure 7). This result supports a biphasic role for $\mathrm{Ca}^{+2}$ in $\mathrm{P} 4$ production in human mural granulosal cells. By pharmacologically increasing intracellular $\mathrm{Ca}^{+2}$ with an ionophore, A23187, basal P4 production was increased. This is contradictory to the findings of Goravanahally et al. (2009), in which A23187 did not affect basal P4 production in cultured bovine luteal cells. Differences between species or the stage of luteinization could explain this difference. Luteinized granulosal cells and luteal cells share several characteristics; however, they are not identical.

In summary, human mural granulosal cells can serve as a valuable model for understanding how increases in intracellular $\mathrm{Ca}^{+2}$ and its downstream targets affect $\mathrm{P} 4$ production in steroidogenic cells. Additionally, P4 production by mural granulosal cells differed among primary infertility type, age, BMI, and pregnancy outcome and may be used to study each of these factors individually. Understanding similarities and differences between previously mentioned factors has the potential to improve IVF protocols and to decrease the incidence of luteal-insufficiency-induced miscarriages. 
A

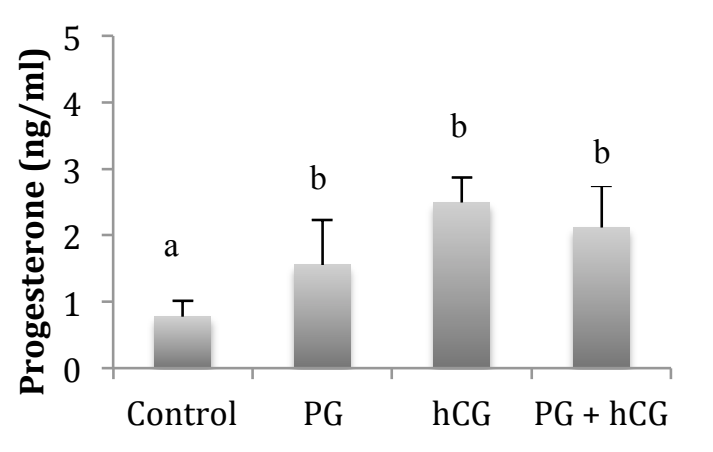

C

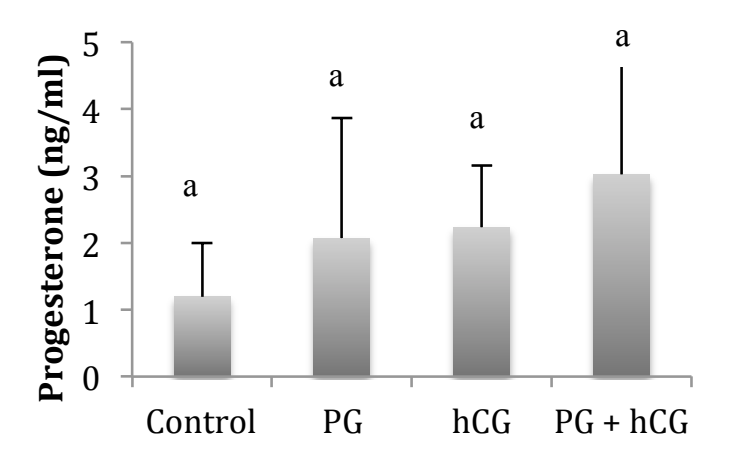

B

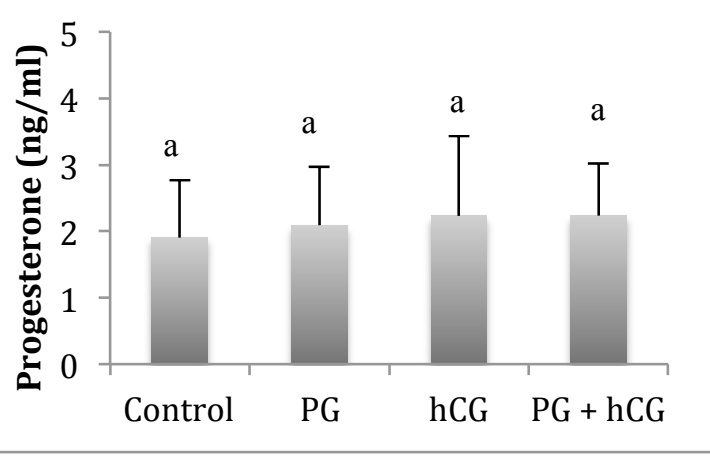

D

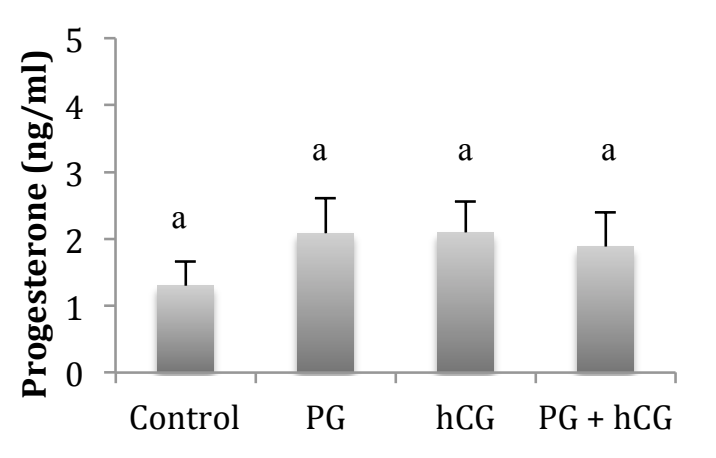

Figure 3.1: Progesterone production by granulosal cells from patients with male factor (A), endometriosis (B), diminished ovarian reserve (C), and tubal (D) primary infertility. 


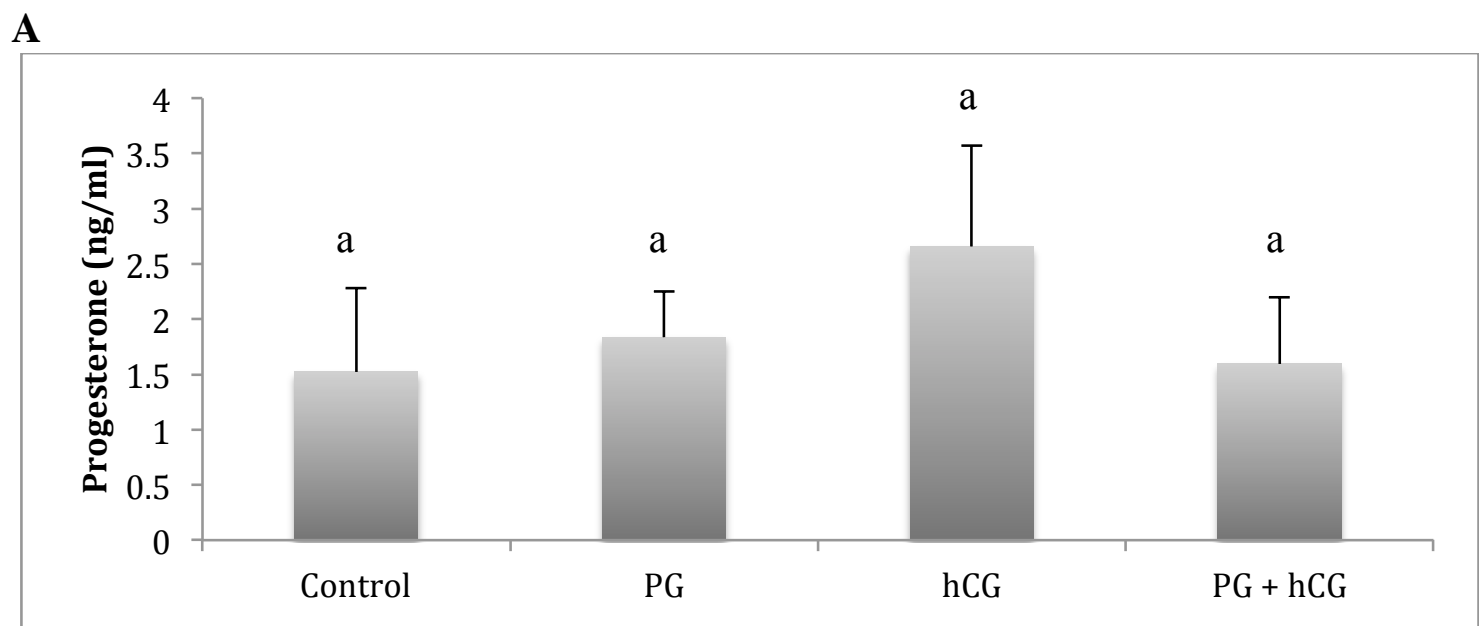

B

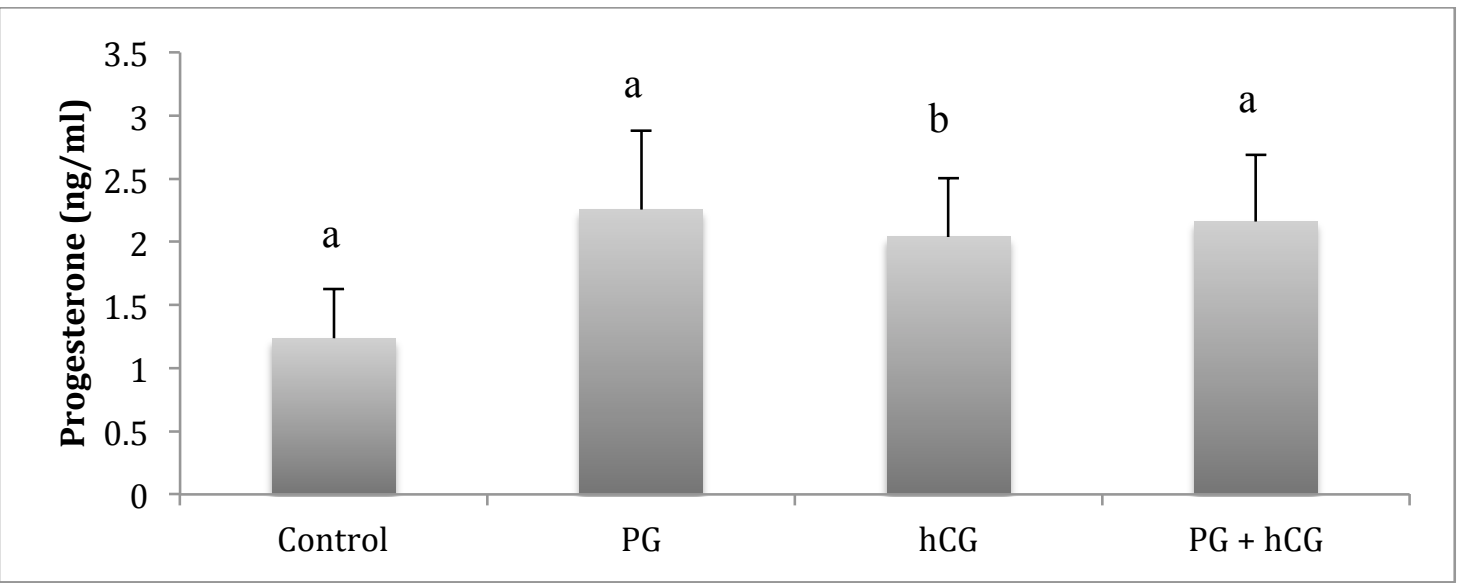

C

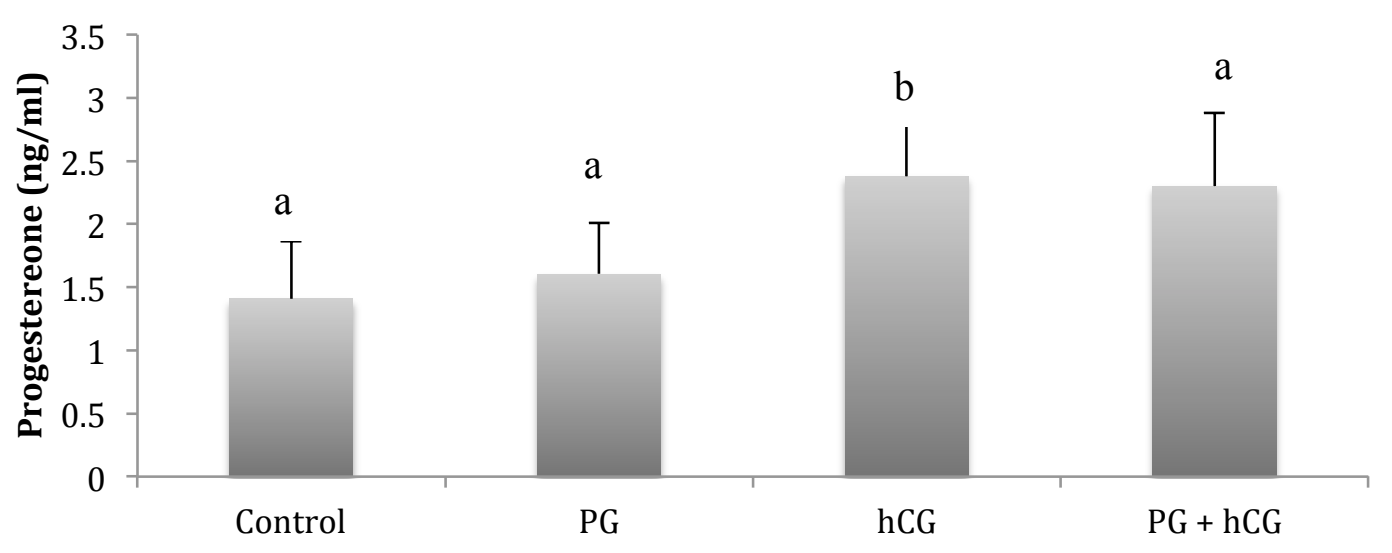

Figure 3.2: Progesterone production in mural granulosal cells was affected by age. Cells from patients who ranged in age from 25-30 $(n=4)$ did not respond to hCG with a significant increase in $\mathrm{P} 4$ production (A). However, cells from other age groups $(31-35, \mathrm{n}=15$ and $36-40, \mathrm{n}=6)$ had significant increases in P4 when stimulated with hCG (ages 31-35 and ages 36-40 in B and C, respectively). 


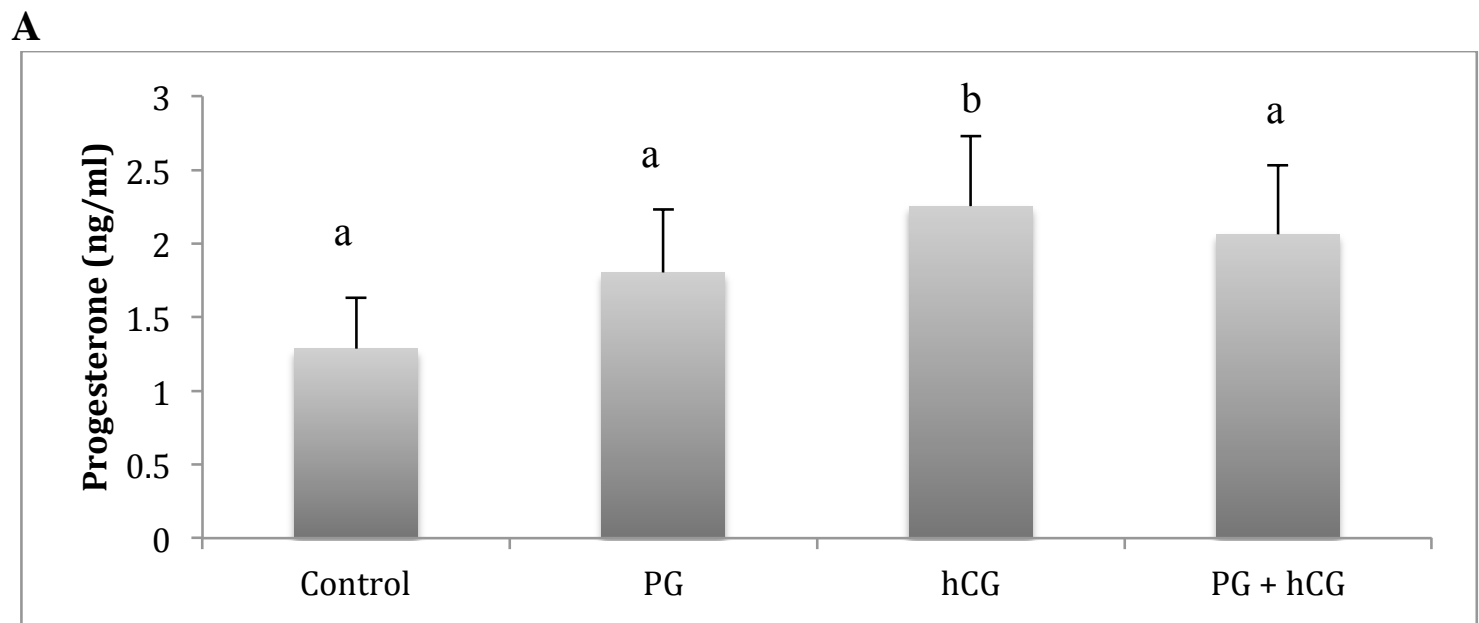

B

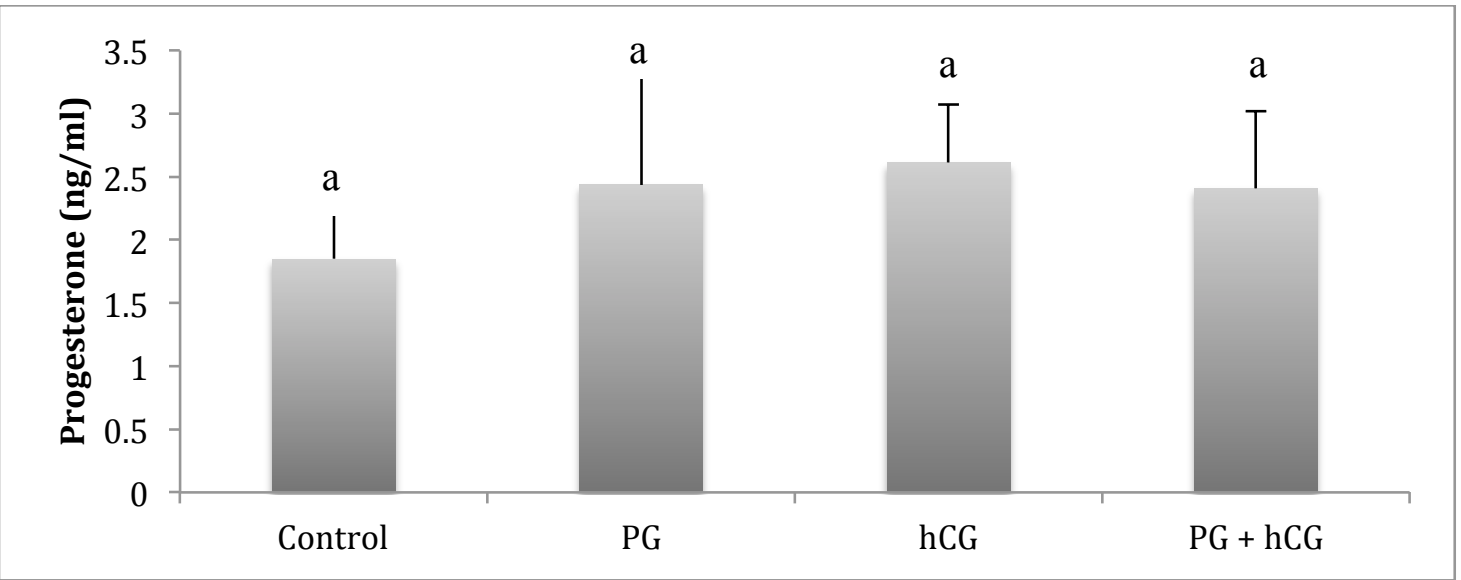

C

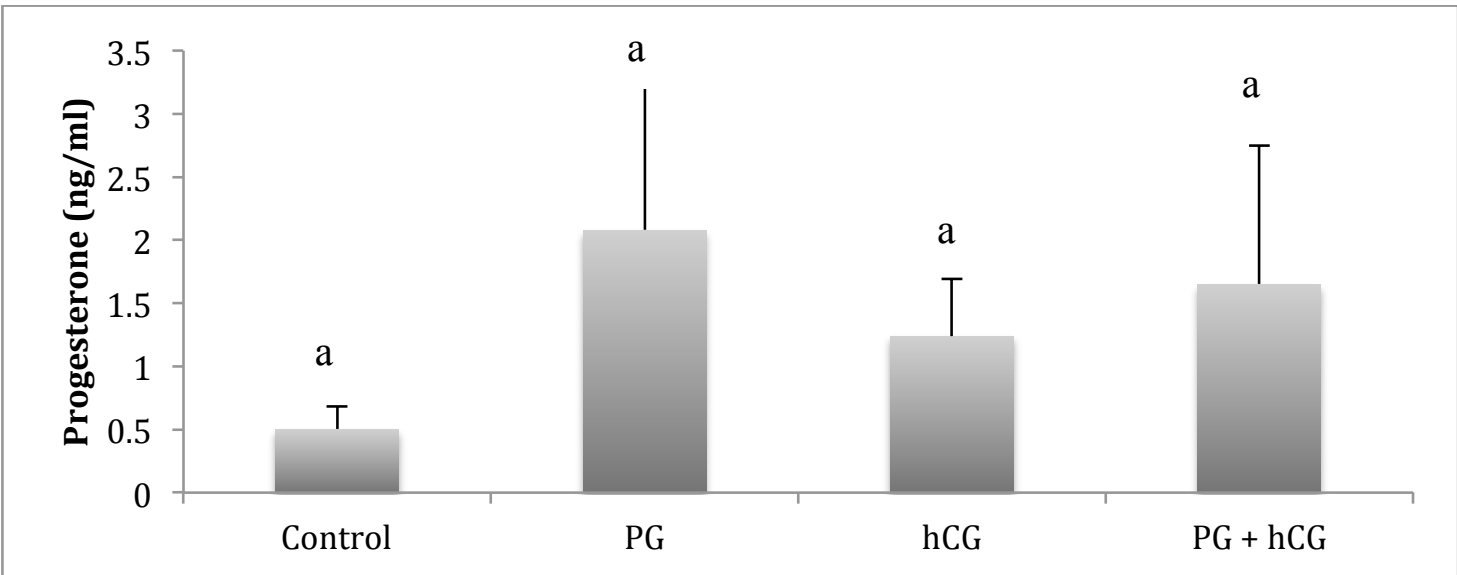

Figure 3.3: Progesterone production in mural granulosal cells was affected by BMI. Cells from patients with $(\mathrm{A})$ normal BMI $(18.5-24.9, \mathrm{n}=16)$ had a significant increase in P4 production when treated with hCG $(\mathrm{P}<0.0001)$. Cells of patients who were categorized as $(\mathrm{B})$ overweight $(\mathrm{BMI}$ of $25-29.9, \mathrm{n}=6)$ or $(\mathrm{C})$ obese $(\mathrm{BMI}>30, \mathrm{n}=3)$ did not have an increase in $\mathrm{P} 4$ production when stimulated with hCG $(\mathrm{P}>0.05)$ 


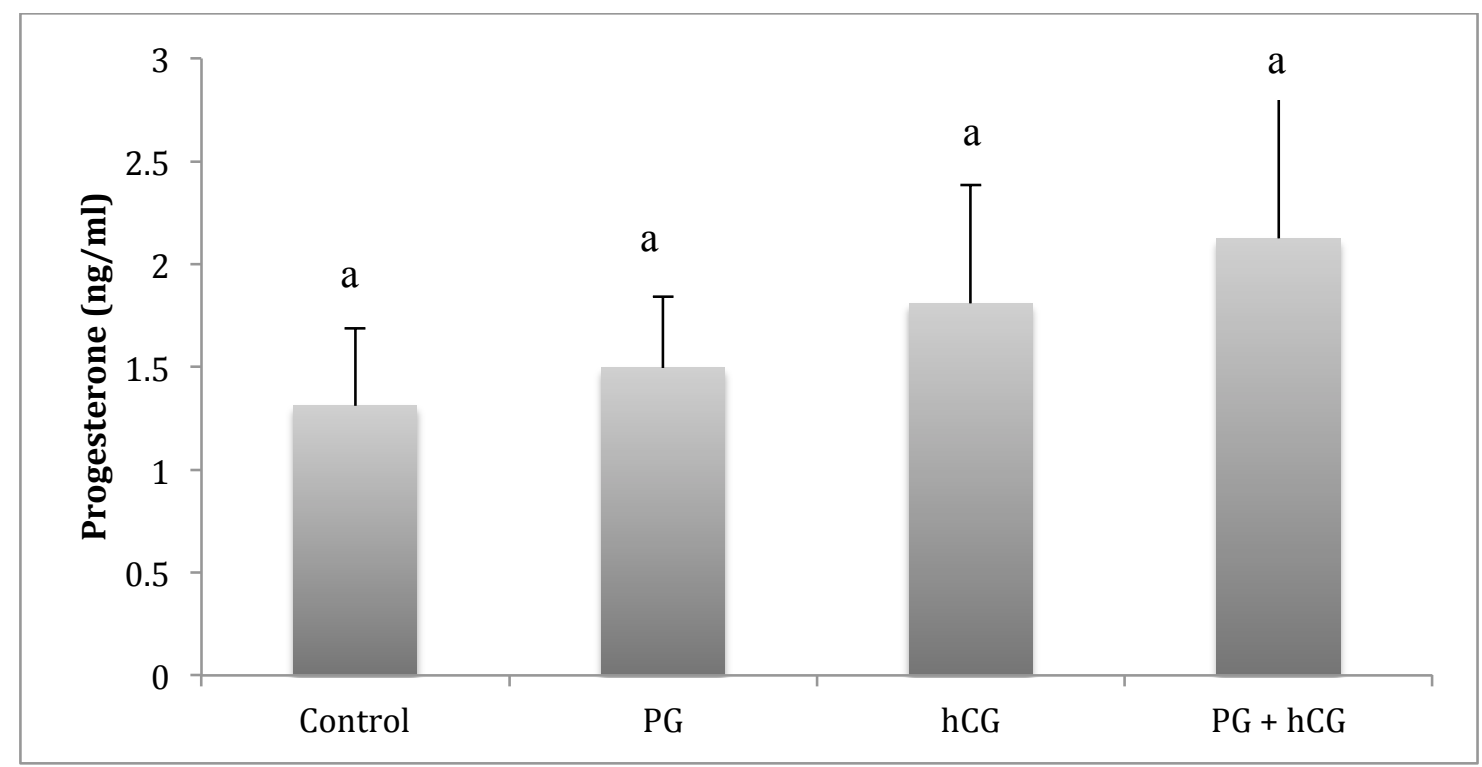

B

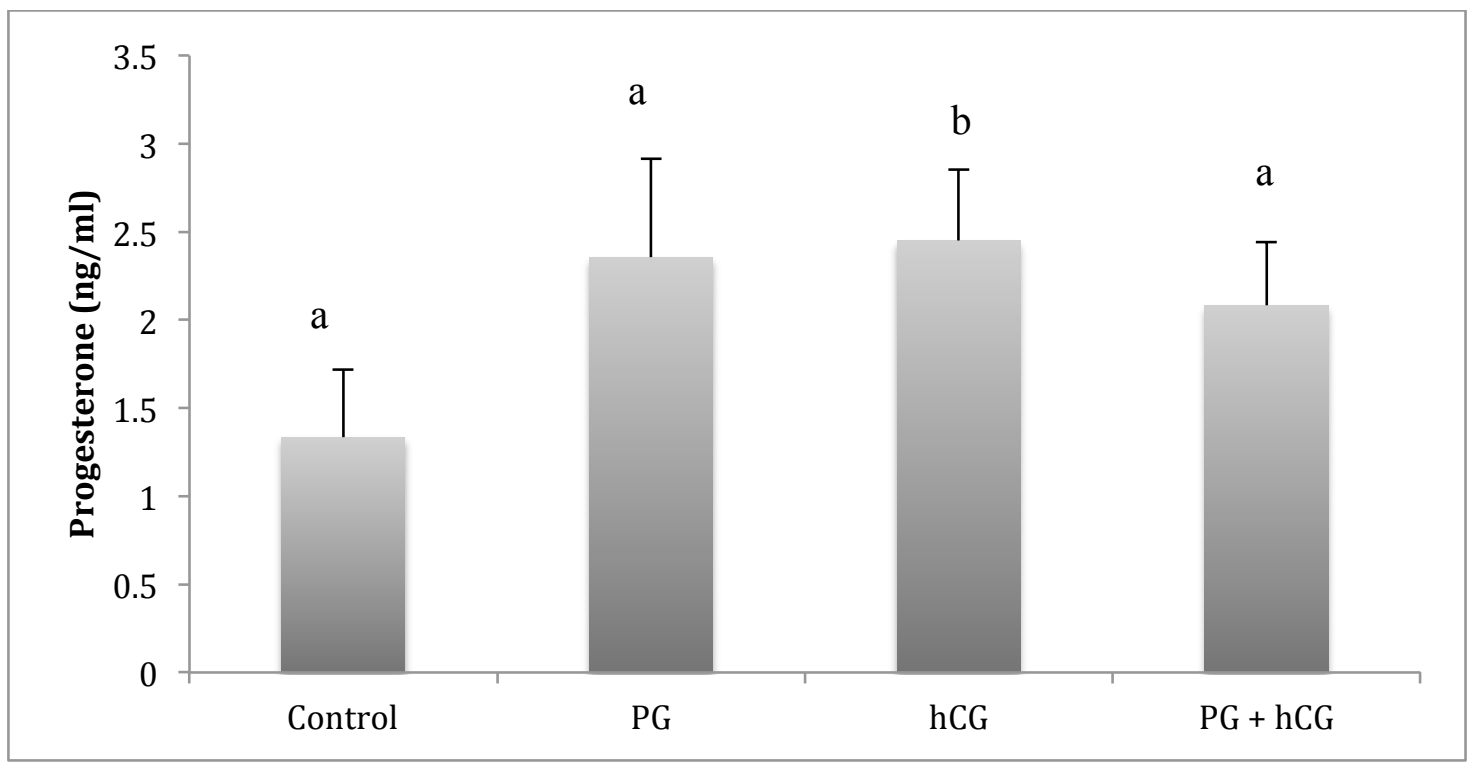

Figure 3.4: Progesterone production in mural granulosal cells was affected by pregnancy status post IVF. Luteinized mural granulosal cells from patients who became pregnant (B) to the IVF cycle produced significantly more $\mathrm{P} 4$ when stimulated with hCG than cells from those who did not become pregnant (A) (3.23 vs. $1.57 \mathrm{ng} / \mathrm{ml}$; $\mathrm{P}<0.05)$. 
A

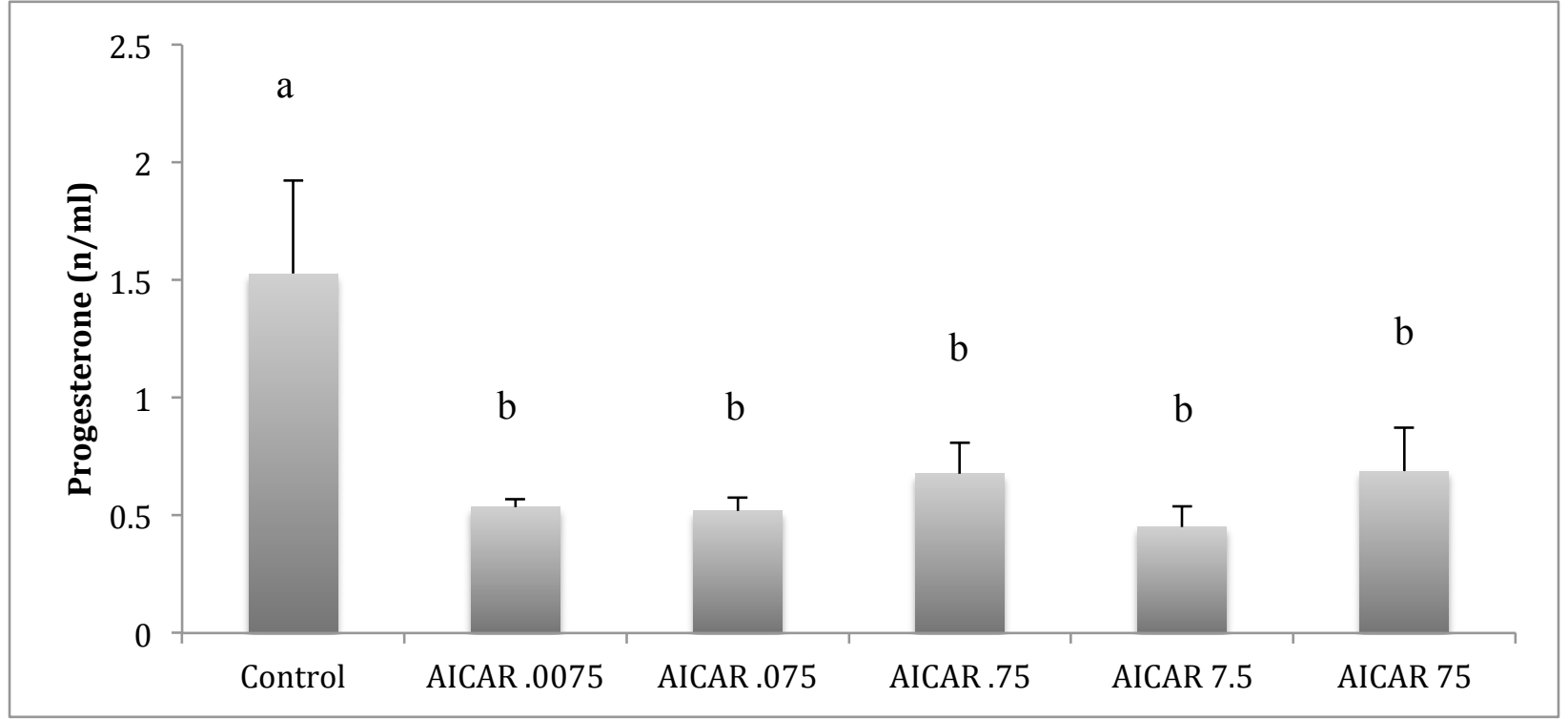

B

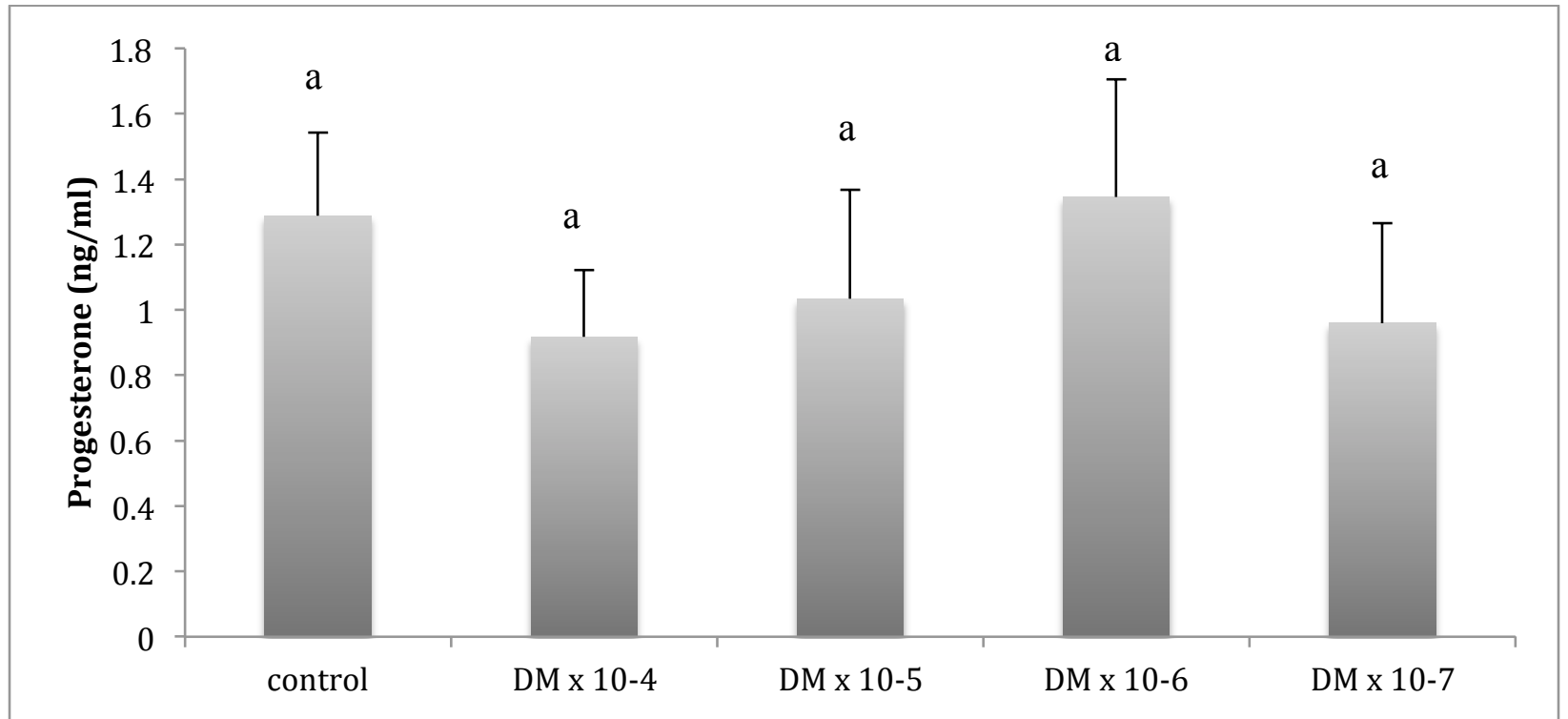

Figure 3.5: The AMPK activator, AICAR, inhibited P4 production by human luteinized mural granulosal cells at all dosages tested (A). In B, the AMPK inhibitor, DM, did not affect basal P4 production. 


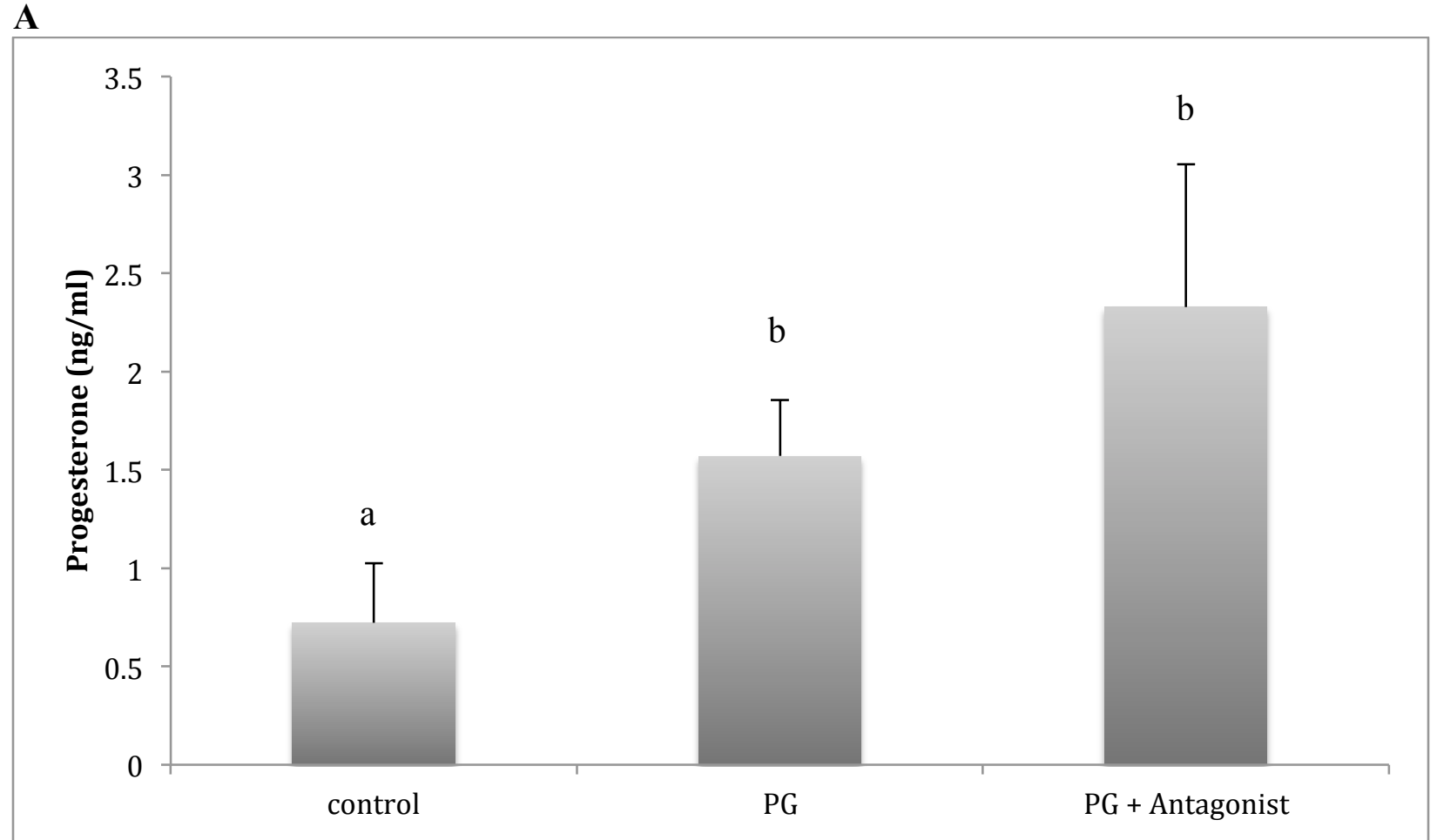

B

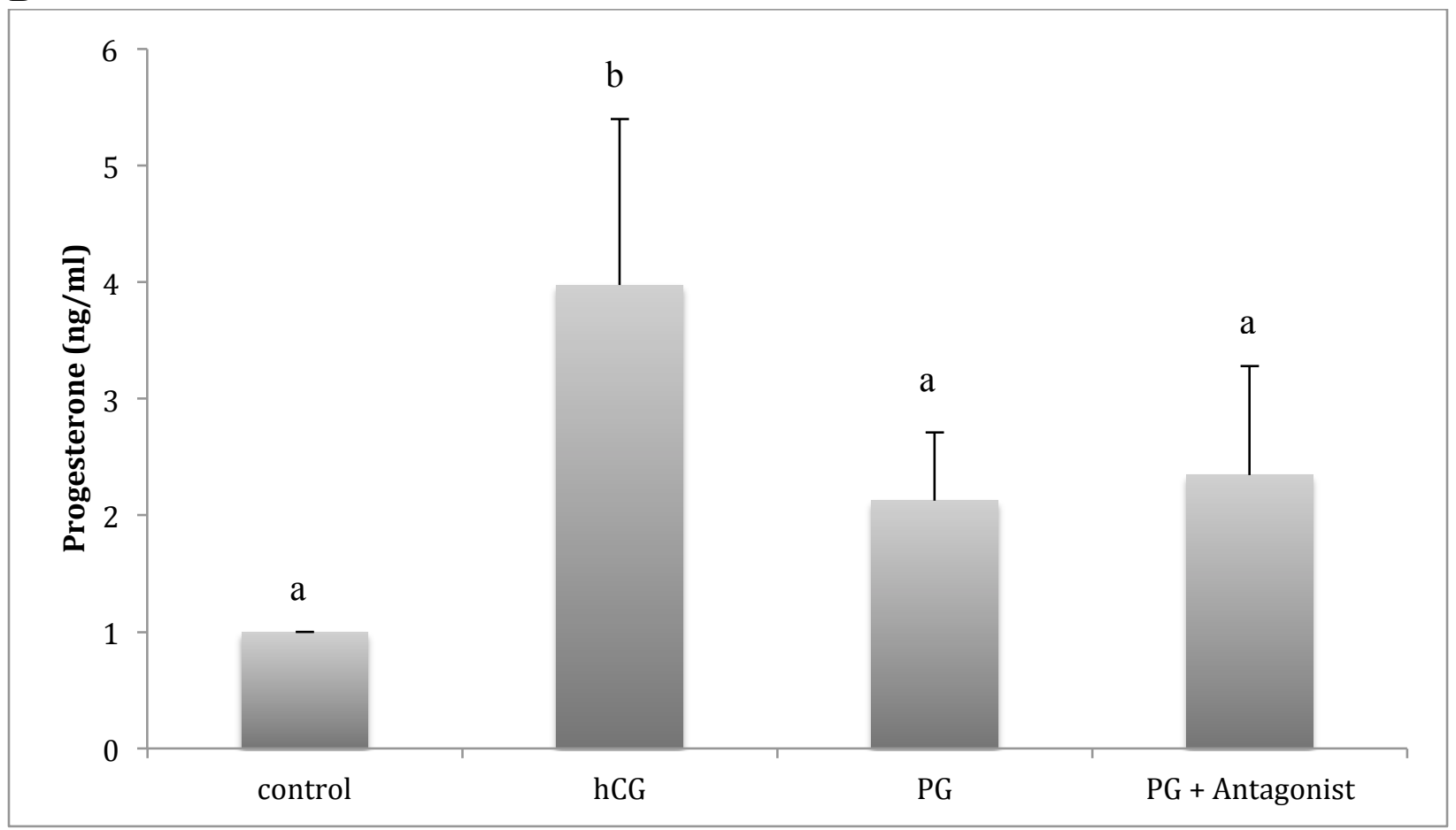

Figure 3.6: $\mathrm{PGF}_{2 \alpha}$ stimulated $\mathrm{P} 4$ production in mural granulosal cells (A) but not in cumulus granulosal cells (B). Adding a PG receptor antagonist, AL 8810, did not block stimulation in mural cells and had no effect in cumulus cells (A). P4 production in cumulus cells was stimulated by hCG, shown in B. 


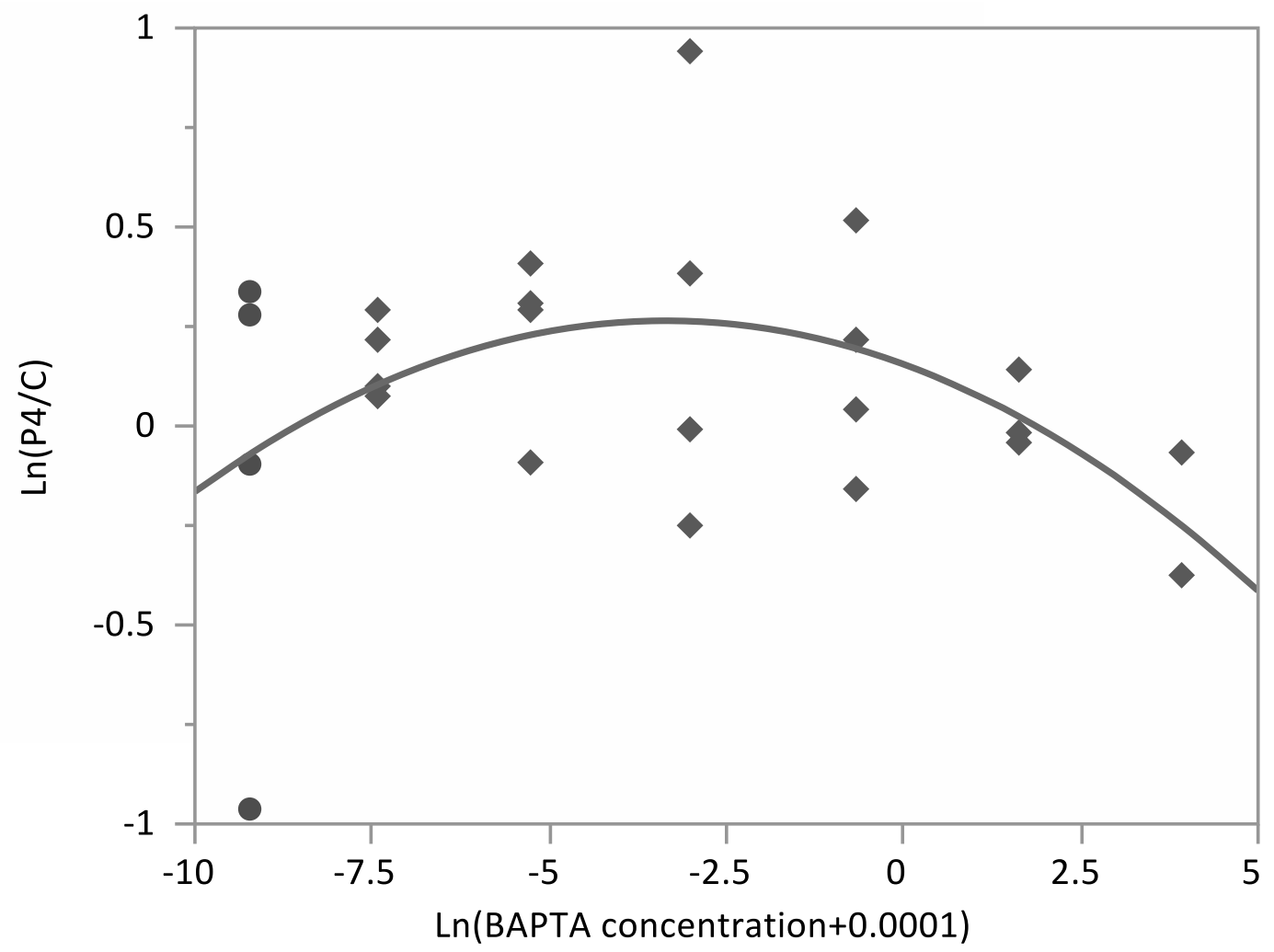

$\operatorname{Ln}(\mathrm{P} 4 / \mathrm{C})=0.2802551+0.0045803 * \operatorname{Ln}($ BAPTA concentration +0.0001$)-0.0097173 *(\operatorname{Ln}(\mathrm{BAPTA}$

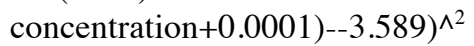

Figure 3.7: BAPTA had a biphasic effect on P4 production in luteinized mural granulosal cells. Data are presented as natural log of the ratio of BAPTA-treated to control values. 
A

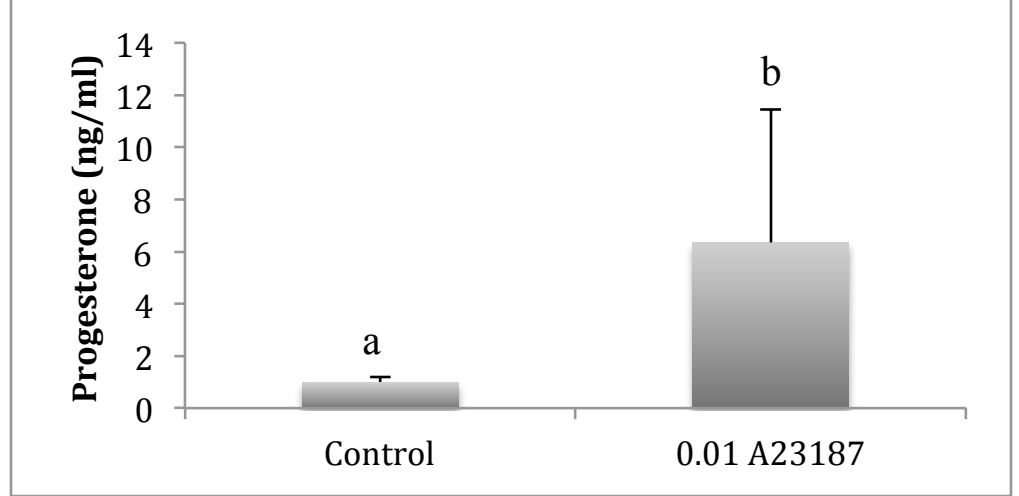

$\mathrm{B}$

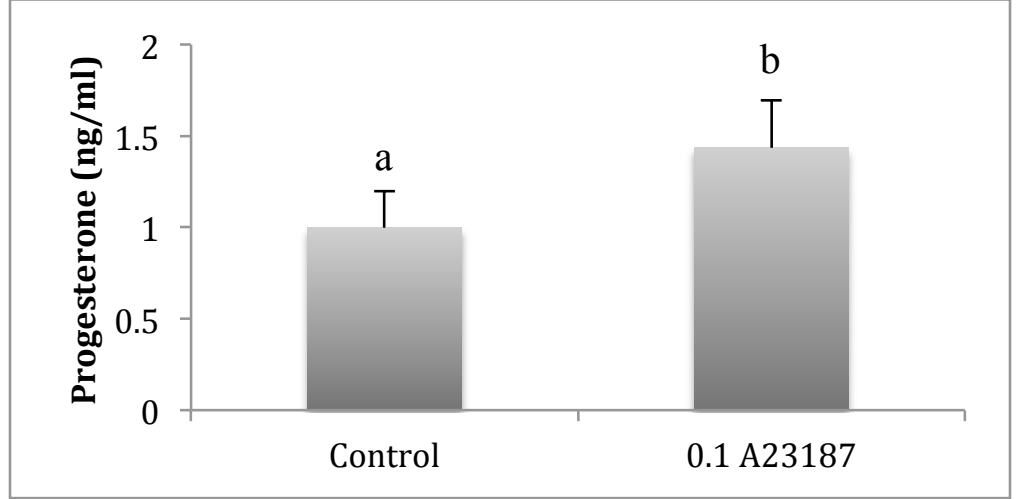

$\mathrm{C}$

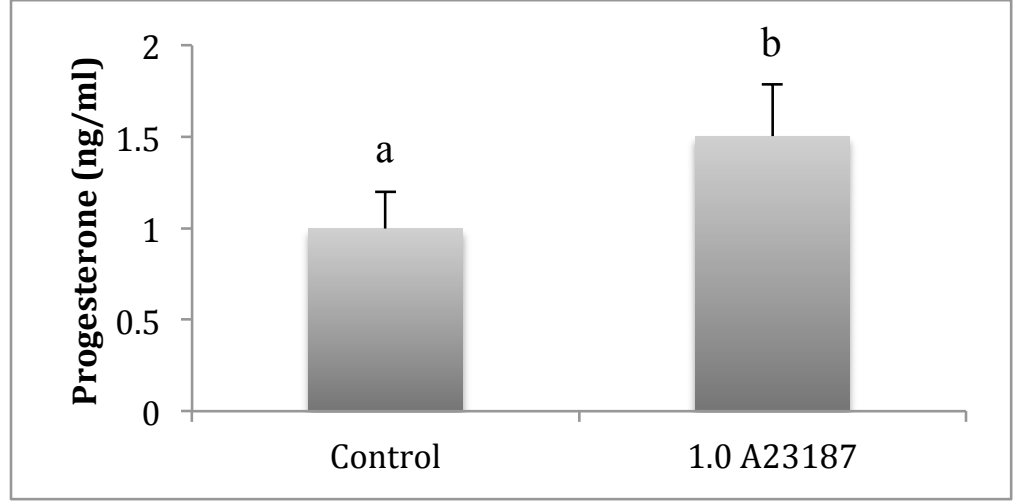

Figure 3.8: Increases in intracellular calcium increased $\mathrm{P} 4$ production in mural granulosal cells. A23187 increased P4 concentrations at $0.01,0.1$, and $1 \mu$ mol concentrations $(\mathrm{A}, \mathrm{B}$, and $\mathrm{C}$ respectively). 


\section{Chapter 5: Literature Cited}

Acosta, T.J., Hayashi, K.G., Ohtani, M., Miyamoto, A. (2003) Local changes in blood flow within the preovulatory follicle wall and early corpus luteum in cows. Reprod 125 (5), 759-767

Acosta, T.J., and Miyamoto, A. (2004) Vascular control of ovarian function: ovulation, corpus luteum formation and regression. Anim Reprod Sci 82,127-140

Acosta, T.J., Yoshizawa, N., Ohtani, M., Miyamoto, A. (2002) Local Changes in Blood Flow Within the Early and Midcycle Corpus Luteum after Prostaglandin F2 $\alpha$ Injection in the Cow. Biol Reprod 66 (3), 651-658

Adams, J.M., Cory, S. (1998) The Bcl-2 protein family: arbiters of cell survival. Science 281 (5381), 1322-1326

Alila, H., Davis, J., Dowd, J., Corrodino, R., Hansel, W. (1990) Differential effects of calcium on progesterone production in small and large bovine luteal cells. J Ster Biochem 36 (6), 687693

Alila, H.W., Dowd, J.P., Corradino, R.A., Harris, W.V., Hansel, W. (1988) Control of progesterone production in small and large bovine luteal cells separated by flow cytometry. $J$ Reprod Fertil 82(2), 645-655

Amini, H., Ahmadiani, A., Gazerani, P. (2005) Determination of metformin in human plasma by high-performance liquid chromatography. J Chromato B 824 (1), 319-322

Anderson, L.E., Wu, Y.L., Tsai, S.J., Wiltbank, M.C. (2001) Prostaglandin F2 $\alpha$ Receptor in the Corpus Luteum: Recent Information on the Gene, Messenger Ribonucleic Acid, and Protein. Biol Reprod 64 (4), 1041-1047

Atli, M.O., Bender, R.W., Mehta, V., Bastos, M.R., Luo, W., Vezina, C.M., and Wiltbank, M.C. (2012) Patterns of Gene Expression in the Bovine Corpus Luteum Following Repeated IntraUterine Infusions of Low Doses of Prostaglandin F2alpha. Biol Reprod 86 (4) 130, 1-13

Auletta, F.J., Flint, A.P.F. (1988) Mechanisms controlling corpus luteum function in sheep, cows, non-human primates, and women, especially in relation to the time of luteolysis. Endocrin $\operatorname{Rev} 9$ 88-105

Auletta, F.J., Kamps, D.L., Pories, S., Bisset, J., Gibson, M. (1984) An intra-corpus luteum site for the luteolytic action of prostaglandin F2 alpha in the rhesus monkey. Prostaglandins 27 (2), $285-298$

Bailey, C., Turner, R. (1996) Metformin. New Eng J Med 334 (9), 574-579 
Bain, J., Plater, L., Elliott, M., Shpiro, N., Hastie, C., Mclauchlan, H., Klevernic, I., Arthur, J., Alessi, D., Cohen, P. (2007) The selectivity of protein kinase inhibitors: a further update.

Biochem J 408, 297-315

Balasch, J. \& Vanrell, J. A. 1987. Corpus luteum insufficiency and fertility: a matter of controversy. Hum Reprod, 2, 557-567.

Bateman, A. (1997) The structure of a domain common to archaebacteria and the homocystinuria disease protei. Trend Biochem Sci 22 (1), 12-13

Bauer, M., Reibiger, I., Spanel-Borowski, K. (2001) Leucocyte proliferation in the bovine corpus luteum. Reprod 121(2), 297-305

Behrman, H.R., Greep, R.O. (1972) Hormonal dependence of cholesterol ester hydrolase in the corpus luteum and adrenal. Horm Metabol Res 4(3), 206-209

Behrman, H.R., Luborsky-Moore, J.L., Pang, C.Y., Wright, K., Dorflinger, L.J. (1979) Mechanisms of PGF2 $\alpha$ action in functional luteolysis. Adv Exp Med Biol 112, 557-575

Belfort, R. Harrison, S. A., Brown, K., Darland, C., Finch, J., Hardies, J., Balas, B., Gastaldelli, A., Tio, F., Pulcini, J., Berria, R., Ma, J.Z., Dwivedi, S., Havranek, R., Fincke, C., DeFronzo, R., Bannayan, G.A., Schenker, S., Cusi, K. (2006) A placebo-controlled trial of pioglitazone in subjects with nonalcoholic steatohepatitis. New Eng J Med (22), 2297-2307

Beling, C.G., Marcus, S.L., Markham, S.M. (1970) Functional Activity of the Corpus Luteum Following Hysterectomy. J Clin Endocrinol Metabol 30 (1), 30-39

Benyo, D.F., Pate, J.L. (1992) Tumor necrosis factor-alpha alters bovine luteal cell synthetic capacity and viability. Endocrinology 130 (2), 854-860

Berardinelli, J.G., Dailey, R.A., Butcher, R.L., Inskeep, E.K. (1979) Source of Progesterone Prior to Puberty in Beef Heifers. J Anim Sci 49 (5), 1276-1280

Berisha, B., Schams, D., Kosmann, M., Amselgruber, W., Einspanier, R. (2000) Expression and Tissue Concentration of Vascular Endothelial Growth Factor, Its Receptors, and Localization in the Bovine Corpus Luteum During Estrous Cycle and Pregnancy. Biol Reprod 63 (4), 1106-1114

Berisha, B., Steffl, M., Amselgruber, W., Schams, D. (2006) Changes in fibroblast growth factor 2 and its receptors in bovine follicles before and after $\mathrm{GnRH}$ application and after ovulation.

Reproduction 131 (2), 319-329

Berridge, M., J., Dawson, R.M., Downes, C.P., Heslop, J.P., Irvine, R. (1983) Changes in the levels of inositol phosphates after agonist-dependent hydrolysis of membrane phosphoinositides. Biochem J 212 (2), 473-482 
Berridge, M.J. (1987) Inositol trisphosphate and diacylglycerol: two interacting second messengers. Annu Rev Biochem 56, 159-93

Bogan, R.L., Hennebold, J.D. (2010) The reverse cholesterol transport system as a potential mediator of luteolysis in the primate corpus luteum. Reproduction 139 (1), 163-176 Bogan, R.L., Murphy, M.J., Hennebold, J.D. (2009) Dynamic changes in gene expression that occur during the period of spontaneous functional regression in the rhesus macaque corpus luteum. Endocrinology 150 (3), 1521-1529

Boris, M., Kaiser, C.C., Goldblatt, A., Elice, M.W., Edelson, S.M., Adams, J.B., Feinstein, D.L. (2007) Effect of pioglitazone treatment on behavioral symptoms in autistic children. . $J$ Neuroinflammation 4 (3)

Bowen-Shauver, J.M., Telleria, C.M. (2003) Luteal regression: a redefinition of the terms. Reprod Biol and Endocrinol 1 (1), 28

Braden, T.D., Gamboni, F., Niswender, G.D. (1988) Effects of prostaglandin F2 alpha-induced luteolysis on the populations of cells in the ovine corpus luteum. Biol Reprod 39 (2), 245-253

Brown, M., Goldstein, J. (1975) Regulation of the activity of the low density lipoprotein receptor in human fibroblasts. Cell 6, 307-316

Brown, M.S., Dana, S.E., Goldstein, J.L. (1975) Cholesterol ester formation in cultured human fibroblasts. Stimulation by oxygenated sterols. J of Biol Chem 250 (10), 4025-4027

Brown, M.S., Goldstein, J.L. (1979) Receptor-mediated endocytosis: insights from the lipoprotein receptor system. PNAS 76 (7), 3330-3337

Buccione, R., Schroeder, A.C., Eppig, J.J. (1990) Interactions between somatic cells and germ cells throughout mammalian oogenesis. Biol Reprod 43 (4), 543-547

Casella, S., Schryver, D.J., Scott, T., Pflugheber, J., Bodensteiner, K.J. (2005)

Immunohistochemical Localization of Basement Membrane Proteins in Rat Ovarian Follicles. Microscop and Microanal 11(Supplement S02), 108-109

Casida LE. Research techniques in physiology of reproduction in the female. In: Chapman AB, editor. Techniques and procedures in animal production research. American Society of Animal Production, Albany; 1959. p. 106-21.

Chaffkin, L.M., Luciano, A.A., and Peluso, J.J. (1992) Progesterone as an autocrine/paracrine regulator of human granulosa cell proliferation. . J Clin Endocrinol \& Metabol 75 (6), 14041408

Choi, J., Jo, M., Lee, E., Choi, D. (2011a) The Role of Autophagy in Corpus Luteum Regression in the Rat. Biol Reprod 85 (3), 465-472 
Choudhary, E., Sen, A., Inskeep, E.K., Flores, J.A. (2005) Developmental Sensitivity of the Bovine Corpus Luteum to Prostaglandin F2 $\alpha$ (PGF2 $\alpha$ ) and Endothelin-1 (ET-1): Is ET-1 a Mediator of the Luteolytic Actions of PGF $2 \alpha$ or a Tonic Inhibitor of Progesterone Secretion? Biol Reprod 72 (3), 633-642

Corton, J.M., Gillespie, J.G., Hawley, S.A., Hardie, D.G. (1995) 5-Aminoimidazole-4

Carboxamide Ribonucleoside. Eur J Biochem 229 (2), 558-565

Davis, J.S., Alila, H.W., West, L.A., Corradino, R.A., Hansel, W. (1988) Acute effects of prostaglandin F2 $\alpha$ on inositol phospholipid hydrolysis in the large and small cells of the bovine corpus luteum. Mole Cell Endocrinol 58 (1), 43-50

Davis, J.S., Rueda, B.R. (2002) The corpus luteum: an ovarian structure with maternal instincts and suicidal tendencies. Front Biosci 7, d1949-1978

Davis, J.S., Weakland, L.L., Weiland, D.A., Farese, R.V., West, L.A. (1987) Prostaglandin F2 alpha stimulates phosphatidylinositol 4,5-bisphosphate hydrolysis and mobilizes intracellular Ca2+ in bovine luteal cells. PNAS 84 (11), 3728-3732

Dharmarajan, A.M., Bruce, N.W., Meyer, G.T. (1985) Quantitative ultrastructural characteristics relating to transport between luteal cell cytoplasm and blood in the corpus luteum of the pregnant rat. Am J Anat 172 (1), 87-99

Eppig, J.J. (2001) Oocyte control of ovarian follicular development and function in mammals. Reproduction 122 (6), 829-838

Fairchild, D.L., Pate, J.L. (1991) Modulation of bovine luteal cell synthetic capacity by interferon-gamma. Biol Reprod 44 (2), 357-363

Fairclough, R.J., Moore, L.G., McGowan, L.T., Peterson, A.J., Smith, J.F., Tervit, H.R., Watkins, W.B. (1980) Temporal relationship between plasma concentrations of 13, 14-dihydro15-keto-prostaglandin F and neurophysin I/II around luteolysis in sheep. . Prostaglandins 20 (2), 199-208

Farin, C.E., Moeller, C.L., Sawyer, H.R., Gamboni, F., Niswender, G.D. (1986) Morphometric analysis of cell types in the ovine corpus luteum throughout the estrous cycle. Biol Reprod 35 (5), 1299-1308

Flint, A.P.F., Sheldrick, E.L. (1982) Ovarian secretion of oxytocin is stimulated by prostaglandin. Nature 29 (5867), 587-588

Friedrich, F., Kemeter, P., Salzer, H., Breitenecker, G. (1975) Ovulation inhibition with human chorionic gonadotrophin,. Acta Endocrinol (Kbh) 78 (332) 
Garrido, C., Saule, S., Gospodarowicz, D. (1993) Transcriptional regulation of vascular endothelial growth factor gene expression in ovarian bovine granulosa cells. . Growth factors $\mathbf{8}$ (2), 109-117

Ginther, O.J., Shrestha, H.K., Fuenzalida, M.J., Shahiduzzaman, A.K.M., Beg, M.A. (2010) Characteristics of Pulses of 13,14-Dihydro-15-Keto-Prostaglandin F2alpha Before, During, and after Spontaneous Luteolysis and Temporal Intrapulse Relationships with Progesterone Concentrations in Cattle. Biol Reprod 82 (6), 1049-1056

Ginther, O.J., Silva, L.A., Araujo, R.R., Beg, M.A. (2007) Temporal Associations among Pulses of 13,14-Dihydro-15-keto-PGF2alpha, Luteal Blood Flow, and Luteolysis in Cattle. Biol Reprod 76 (3), 506-513

Girsh, E., Greber, Y., Meidan, R. (1995) Luteotrophic and luteolytic interactions between bovine small and large luteal-like cells and endothelial cells. Biol Reprod 52 (4), 954-962

Goldstein, J.L., and Brown, M.S. (2009) The LDL Receptor. Arterio, Throm, and Vascul Biol 29 (4), 431-438

Goravanahally, M.P., Salem, M., Yao, J., Inskeep, E.K., Flores, J.A. (2009) Differential Gene Expression in the Bovine Corpus Luteum During Transition from Early Phase to Midphase and Its Potential Role in Acquisition of Luteolytic Sensitivity to Prostaglandin F2 Alpha. Biol Reprod 80 (5), 980-988

Goravanahally, M.P., Sen, A., Inskeep, E.K., Flores, J.A. (2007) PKCepsilon and an increase in intracellular calcium concentration are necessary for PGF2alpha to inhibit LH-stimulated progesterone secretion in cultured bovine steroidogenic luteal cells. Reprod Biol Endocrinol $5(37)$

Goyeneche, A.A., Calvo, V., Gibori, G., Telleria, C.M. (2002) Androstenedione Interferes in Luteal Regression by Inhibiting Apoptosis and Stimulating Progesterone Production. Biol Reprod 66 (5), 1540-1547

Gruzman, A., Babai, G., Sasson, S. (2009) Adenosine Monophosphate-Activated Protein Kinase (AMPK) as a New Target for Antidiabetic Drugs: A Review on Metabolic, Pharmacological and Chemical Considerations. Rev Diabet Stud 6 (1), 13-36

Guraya, S.S. (1971) Morphology, histochemistry, and biochemistry of human ovarian compartments and steroid hormone synthesis. Physiol Rev 51, 785-807

Gutierrez, C.G., Ralph, J.H., Telfer, E.E., Wilmut, I.,Webb, R. (2000) Growth and Antrum Formation of Bovine Preantral Follicles in Long-Term Culture In Vitro. Biol Reprod 62 (5), $1322-1328$ 
Hansen, T.R., Randel, R.D., Segerson, E.C., Rutter, L.M., Harms, P.G. (1987) Corpus Luteum Function Following Spontaneous or Prostaglandin-Induced Estrus in Brahman Cows and Heifers. J Anim Sci 65 (2), 524-533

Hardie, D.G. (2008) AMPK: a key regulator of energy balance in the single cell and the whole organism. Int J Obes 32 (S4), S7-S12

Hardie, D.G., Ross, F.A., Hawley, S.A. (2012) AMPK: a nutrient and energy sensor that maintains energy homeostasis. Nat Rev Mol Cell Biol 13 (4), 251-62

Hearn, J.P., Webley, G.E., Gidley-Baird, A.A. (1991) Chorionic gonadotrophin and embryomaternal recognition during the peri-implantation period in primates. J Reprod Fertil 92 (2), 497-509

Hild-petito, S., Stouffer, R.L., and Brenner, R.M. (1988) Immunocytochemical Localization of Estradiol and Progesterone Receptors in the Monkey Ovary Throughout the Menstrual Cycle Endocrinology 123 (6), 2896-2905

Hou, X., Arvisais, E.W., Davis, J.S. (2010) Luteinizing hormone stimulates mammalian target of rapamycin signaling in bovine luteal cells via pathways independent of AKT and mitogenactivated protein kinase: modulation of glycogen synthase kinase 3 and AMP-activated protein kinase. Endocrinology 151 (6), 2846-2857

Hoyer, P.B., Fitz, T.A., Niswender, G.D. (1984) Hormone-Independent Activation of Adenylate Cyclase in Large Steroidogenic Ovine Luteal Cells Does Not Result in Increased Progesterone Secretion. Endocrinology 114 (2), 604-608

Hsueh, A.J., Adashi, E.Y., Jones, P.B., and Welsh JR, T.H. (1984) Hormonal Regulation of the Differentiation of Cultured Ovarian Granulosa Cells Endocrin Rev 5 (1), 76-127

Hu, J., Zhang, Z., Shen, W.J., Azhar, S. (2010) Review Cellular cholesterol delivery, intracellular processing and utilization for biosynthesis of steroid hormones. Nut Metabol 7, 47-72.

Hustace, J.L., Firshman, A.M., Mata, J.E. (2009) Pharmacokinetics and bioavailability of metformin in horses. Am J Vet Res 70 (5), 665-668

Inskeep, E.K. (1973) Potential Uses of Prostaglandins in Control of Reproductive Cycles of Domestic Animals. J Anim Sci 36 (6), 1149-1157

Isakovic, A., Harhaji, L., Stevanovic, D., Markovic, Z., Sumarac-Dumanovic, M., Starcevic, V., Micic, D., Trajkovic, V. (2007) Dual antiglioma action of metformin: cell cycle arrest and mitochondria-dependent apoptosis. Cell Mol Life Sci 64 (10), 1290-1302 
Jeppesen, J.V., Kristensen, S.G., Nielsen, M.E., Humaidan, P., Dal Canto, M., Fadini, R., Schmidt, K.T., Ernst, E., Yding Andersen, C. (2012) LH-Receptor Gene Expression in Human Granulosa and Cumulus Cells from Antral and Preovulatory Follicles. J Clin Endocrinol Metabol 97(8), E1524- E1531

Juengel, J.L., Garverick, H.A., Johnson, A.L., Youngquist, R.S., Smith, M.F. (1993) Apoptosis during luteal regression in cattle. Endocrinology 132 (1), 249-254

Juengel, J.L., Melner, M.H., Clapper, J.A., Turzillo, A.M., Moss, G.E., Nett, T.M., Niswender, G.D. (1998) Steady-state concentrations of mRNA encoding two inhibitors of protein kinase $\mathrm{C}$ in ovine luteal tissue. J Reprod Fertil 113 (2), 299-305

Kang, J.H. (2014) Protein Kinase C (PKC) Isozymes and Cancer. New J Sci

Keisler, D.H., Keisler, L.W. (1989) Formation and function of GnRH-induced subnormal corpora lutea in cyclic ewes. J Reprod Fertil 87 (1), 265-273

Kerr, J.F., Wyllie, A.H., Currie, A.R. (1972) Apoptosis: a basic biological phenomenon with wide-ranging implications in tissue kinetics. Brit J Can 26 (4), 239

Keyes, P., Gadsby, J., Yuh, K., Bill, C.r. (1983) The corpus luteum. Int Rev Physiol 27, 57-97

Kim, J., Kundu, M., Viollet, B., Guan, K.L. (2011) AMPK and mTOR regulate autophagy through direct phosphorylation of Ulk1. Nat Cell Biol 1 3(2), 132-141

Kindahl, H., Edqvist, L.E., Granstrom, E., Bane, A. (1976) The release of prostaglandin F2 $\alpha$ as reflected by 15 -keto-13, 14-dihydroprostaglandin F2 $\alpha$ in the peripheral circulation during normal luteolysis in heifers. Prostaglandins 11, 871-876

Kliem, H., Berisha, B., Meyer, H.H.D., Schams, D. (2009) Regulatory changes of apoptotic factors in the bovine corpus luteum after induced luteolysis. Mol Reprod Dev 76 (3), 220-230

Klionsky, D.J., Emr, S.D. (2000) Autophagy as a regulated pathway of cellular degradation. Science 290 (5497), 1717-1721

Knickerbocker, J.J., Wiltbank, M.C., Niswender, G.D. (1988) Mechanisms of luteolysis in domestic livestock. . Dom Anim Endocrinol 5 (2), 91-107

Ko, C., Gieske, M.C., Al-Alem, L., Hahn, Y., Su, W., Gong, M.C., Iglarz, M., Koo, Y. (2006) Endothelin-2 in Ovarian Follicle Rupture. Endocrinology 147 (4), 1770-1779

Kobayashi, S., Berisha, B., Amselgruber, W.M., Schams, D., Miyamoto, A. (2001) Production and localisation of angiotensin II in the bovine early corpus luteum: a possible interaction with luteal angiogenic factors and prostaglandin F2 alpha. $J$ Endocrinol 170 (2), 369-380 
Kotwica, J., Rekawiecki, R., Duras, M. (2004) Stimulatory influence of progesterone on its own synthesis in bovine corpus luteum. Bull Vet Inst Pulawy 48 (2), 139-146

Kotwica, J., Skarzynski, D. (1993) Influence of oxytocin removal from the corpus luteum on secretory function and duration of the oestrous cycle in cattle. J Reprod Fertil 97 (2), 411-417

Lee, J., McCracken, J.A., Banu, S.K., Arosh, J.A. (2013) Intrauterine Inhibition of Prostaglandin Transporter Protein Blocks Release of Luteolytic PGF2alpha Pulses Without Suppressing Endometrial Expression of Estradiol or Oxytocin Receptor in Ruminants. Biol Reprod 89 (2), 27

Legro, R., Barnhart, H., Schlaff, W., Carr, B., Diamond, M., Carson, S., Steinkampf, M., Coutifaris, C., McGovern, P., Cataldo, N., Gosman, G., Nestler, J., Giudice, L., Ewens, K., Spielman, R., Leppert, P., Myers, E. (2008) Ovulatory Response to Treatment of Polycystic Ovary Syndrome Is Associated with a Polymorphism in the STK11 Gene. J Clin Endocrinol Metabol 93 (3), 792-800

Legro, R. S., Barnhart, H. X., Schlaff, W. D., Carr, B. R., Diamond, M. P., Carson, S. A., Steinkampf, M. P., Coutifaris, C., McGovern, P. G., Cataldo, N. A., Gosman, G. G., Nestler, J. E., Giudice, L. C., Leppert, P. C. \& Myers, E. R. Clomiphene, Metformin, or Both for Infertility in the Polycystic Ovary Syndrome. N Engl J Med, 356, 551-566

Leridon, H. (2004) Can assisted reproduction technology compensate for the natural decline in fertility with age? A model assessment. Human Reprod 19 (7), 1548-1553

Lestavel, S., Fruchart, J.C. (1994) Lipoprotein receptors. Cell Mol Biol 40 (4), 461-481

Liptak, A.R., Sullivan, B.T., Henkes, L.E., Wijayagunawardane, M.P.B., Miyamoto, A., Davis, J.S., Rueda, B.R., Townson, D.H. (2005) Cooperative Expression of Monocyte Chemoattractant Protein 1 Within the Bovine Corpus Luteum: Evidence of Immune Cell-Endothelial Cell Interactions in a Coculture System. Biol Reprod 72 (5), 1169-1176

Liu, X., Chhipa, R.R., Nakano, I., Dasgupta, B. (2014) The AMPK Inhibitor Compound C Is a Potent AMPK-Independent Antiglioma Agent. Mol Can Therap 13 (3), 596-605

Liu, Y.X., Hsueh, A.J. (1986) Synergism between granulosa and theca-interstitial cells in estrogen biosynthesis by gonadotropin-treated rat ovaries: studies on the two-cell, twogonadotropin hypothesis using steroid antisera. Biol Reprod 35 (1), 27-36

Lucy, M.C., Stevenson, J.S., Call, E.P. (1986) Controlling First Service and Calving Interval by Prostaglandin F2 $\alpha$, Gonadotropin-Releasing Hormone, and Timed Insemination. J Dairy Sci $69(8), 2186-2194$

Mamluk, R., Chen, D., Greber, Y., Davis, J.S., Meidan, R. (1998) Characterization of messenger ribonucleic acid expression for prostaglandin F2 alpha and luteinizing hormone receptors in various bovine luteal cell types. Biol Reprod 58 (3), 849-856 
Mann, G.E., Lamming, G.E. (2006) Timing of prostaglandin ${ }_{\mathrm{F} 2 \alpha}$ release episodes and oxytocin receptor development during luteolysis in the cow. Anim Reprod Sci 93 (3), 328-336

Martin, G.G., Talbot, P. (1981) The role of follicular smooth muscle cells in hamster ovulation. $J$ Exp Zool 216 (3), 469-482

Martin, S.J., Green, D.R. (1995) Protease activation during apoptosis: death by a thousand cuts? Cell 82 (3), 349-352

Matsui, M., Miyamoto, A. (2009) Evaluation of ovarian blood flow by colour Doppler ultrasound: practical use for reproductive management in the cow. Vet $J 181$ (3), 232-240

McCracken, J.A. (1971) Prostaglandin F2 $\alpha$ and corpus luteum regression. Ann NY Acad Sci 180 (1), 456-469

McCracken, J.A., Custer, E.E., Eldering, J.A., Robinson, A.G. (1996) The central oxytocin pulse generator: a pacemaker for the ovarian cycle. Acta Neurobiol Exp 56 (3), 819-832

McCracken, J.A., Custer, E.E., Lamsa, J.C. (1999) Luteolysis: a neuroendocrine-mediated event. Physiol Rev 79 (2), 263-323

McNatty, K.P., Makris, A., Degrazia, C., Rapin, O., Ryan, K.J. (1979) The Production of Progesterone, Androgens, and Estrogens by Granulosa Cells, Thecal Tissue, and Stromal Tissue from Human Ovaries in Vitro. J Clin Endocrinol Metabol 49 (5), 687-699

Merrill, G., Kurth, E., Hardie, D., Winder, W. (1997) AICA riboside increases AMP-activated protein kinase, fatty acid oxidation, and glucose uptake in rat muscle. Amer J Physiol Endocrinol Metabol 273 (6), E1107-E1112

Milvae, R.A., Hansel, W. (1983) Prostacyclin, prostaglandin F2 alpha and progesterone production by bovine luteal cells during the estrous cycle. Biol Reprod 29 (5), 1063-1068

Miyamoto, A., Shirasuna, K., Wijayagunawardane, M.P.B., Watanabe, S., Hayashi, M., Yamamoto, D., Matsui, M., Acosta, T.J. (2005) Blood flow: a key regulatory component of corpus luteum function in the cow. Dom Anim Endocrinol 29 (2), 329-339

Morales, C., García-Pardo, L., Reymundo, C., Bellido, C., Sánchez-Criado, J.E., Gaytán, F. (2000) Different patterns of structural luteolysis in the human corpus luteum of menstruation. Human Reprod 15( 10), 2119-2128

Nagata, S. (1997) Apoptosis by death factor. Cell 88 (3), 355-365

Nett, T.M., McClellan, M.C., Niswender, G.D. (1976) Effects of Prostaglandins on the Ovine Corpus Luteum: Blood Flow, Secretion of Progesterone and Morphology. Biol Reprod 15(1), 66-78 
Neuvians, T.P., Schams, D., Berisha, B., Pfaffl, M.W. (2004) Involvement of Pro-Inflammatory Cytokines, Mediators of Inflammation, and Basic Fibroblast Growth Factor in Prostaglandin F2 $\alpha$-Induced Luteolysis in Bovine Corpus Luteum. Biol Reprod 70 (2), 473-480

Niswender, G., Nett, T. (1994) Corpus luteum and its control in infraprimate species. In 'The Physiology of Reproduction.' (Eds. E Knobil and JD Neil). (Raven Press: New York)

Niswender, G.D. (2002) Molecular control of luteal secretion of progesterone. Reproduction 123 (3), 333-339

Niswender, G.D., Juengel, J.L., Silva, P.J., Rollyson, M.K., McIntush, E.W. (2000) Mechanisms Controlling the Function and Life Span of the Corpus Luteum. Physiol Rev 80 (1), 1-29

O'Shea, J.D., Cran, D.G., Hay, M.F. (1979) The small luteal cell of the sheep. J Anat 128 (2), 239-251

Papadopoulos, V., Amri, H., Boujrad, N., Cascio, C., Culty, M., Garnier, M., Hardwick, M., Drieu, K. (1997) Peripheral benzodiazepine receptor in cholesterol transport and steroidogenesis. Ster 62 (1), 21-28

Park, S.H., Gammon, S.R., Knippers, J.D., Paulsen, S.R., Rubink, D.S., Winder, W.W. (2002) Phosphorylation-activity relationships of AMPK and acetyl-CoA carboxylase in muscle. $J$ Appl Physiol 92 (6), 2475-2482

Pate, J.L. (1988a) Regulation of prostaglandin synthesis by progesterone in the bovine corpus luteum. Prostaglandins 36 (3), 303-315

Pate, J.L. (1995) Involvement of immune cells in regulation of ovarian function. $J$ Reprod Fertil Supplement 49 365-377

Patton, P.E., and Stouffer, R.L. (1991) Current understanding of the corpus luteum in women and nonhuman primates. . Clini Obstet Gynecol 34 (1), 127-143

Peluso, J.J. (1997) Placing progesterone in the apoptotic pathway. Trends Endocrinol Metabol 8 (7), 267-271

Penny, L.A. (2000) Monocyte chemoattractant protein 1 in luteolysis. Rev Reprod 5(2), 63-66

Penny, L.A., Armstrong, D., Bramley, T.A., Webb, R., Collins, R.A., Watson, E.D. (1999) Immune cells and cytokine production in the bovine corpus luteum throughout the oestrous cycle and after induced luteolysis. J Reprod Fertil 115 (1), 87-96

Piper, P.J., Vane, J.R., Wyllie, J.H. (1970) Inactivation of prostaglandins by the lungs. Nature 225 (5233), 600-604

Pursley, J.R., Mee, M.O., Wiltbank, M.C. (1995) Synchronization of ovulation in dairy cows using PGF2 $\alpha$ and GnRH. Theriogenology 44 (7), 915-923 
Rao, C.V. (1974) Characterization of Prostaglandin Receptors in the Bovine Corpus Luteum Cell Membranes. J Biol Chem 249( 22), 7203-7209

Redmer, D.A., Reynolds, L.P. (1996) Angiogenesis in the ovary. Rev Reprod 1 (3), 182-192

Rendle, D.I., Rutledge, F., Hughes, K.J., Heller, J., Durham, A.E. (2013) Effects of metformin hydrochloride on blood glucose and insulin responses to oral dextrose in horses. Equine Vet J 45 (6), 751-754

Reynolds, L.P., Grazul-Bilska, A., Killilea, S., Redmer, D. (1994) Mitogenic factors of corpora lutea. Prog Growth Fact Res 5 (2), 159-175

Reynolds, L.P., Grazul-Bilska, A.T., Redmer, D.A. (2000) Angiogenesis in the corpus luteum. Endocrine 12 (1), 1-9

Roberts, R.M., Xie, S., Mathialagan, N. (1996) Maternal recognition of pregnancy. Biol Reprod 54 (2), 294-302

Robertson, J.E., Baker, R.D., (1969) Role of female sex steroids on possible regulation of oocyte maturation. Second Annual Meeting of the Society for the Study of Reproduction, University of California, Davis (Abstract 57)

Robinson, R.S., Hammond, A.J., Mann, G.E., Hunter, M.G. (2008) A novel physiological culture system that mimics luteal angiogenesis. Reproduction 135 (3), 405-413

Robinson, R.S., Nicklin, L.T., Hammond, A.J., Schams, D., Hunter, M.G., Mann, G.E. (2007) Fibroblast Growth Factor 2 Is More Dynamic than Vascular Endothelial Growth Factor A During the Follicle-Luteal Transition in the Cow. Biol Reprod 77 (1), 28-36

Robinson, R.S., Woad, K.J., Hammond, A.J., Laird, M., Hunter, M.G., Mann, G.E. (2009) Angiogenesis and vascular function in the ovary. Reproduction 138 (6), 869-881

Rodgers, R.J., Irving-Rodgers, H.F. (2010) Formation of the Ovarian Follicular Antrum and Follicular Fluid. Biol Reprod 82 (6), 1021-1029

Rothchild, I. (1981) The regulation of the mammalian corpus luteum Rec Prog Horm Res 37, 183-298

Rowson, L., Trevit, R., Brand, A. (1972) The use of prostaglandins for synchronizationof oestrus in cattle. J Reprod Fertil 29(145 (abstract))

Rueda, B., Hamernik, D., Hoyer, P., Tilly, J. (1997) Potential regulators of physiological cell death in the corpus luteum In 'Serono Symposia: Cell Death in Reproductive Physiology.'. (Eds. T JL, S J and T M) pp. 161-181. (Springer-Verlag New York, Inc.: New York ) 
Rueda, B.R., Hendry, I.R., Hendry, W.J., Stormshak, F., Slayden, O.D., Davis, J.S. (2000) Decreased Progesterone Levels and Progesterone Receptor Antagonists Promote Apoptotic Cell Death in Bovine Luteal Cells. Biol Reprod 62 (2), 269-276

Russell, D.L., Salustri, A. (2006) Extracellular matrix of the cumulus-oocyte complex. Sem Reprod Med 24 (4), 217-227

Sawyer, H.R., Niswender, K.D., Braden, T.D., Niswender, G.D. (1990) Nuclear changes in ovine luteal cells in response to PGF2 $\alpha$. Dom Anim Endocrinol 7 (2), 229-237

Scaramuzzi, R.J., Baird, D.T., Campbell, B.K., Driancourt, M.A., Dupont, J., Fortune, J.E., Gilchrist, R.B., Martin, G.B., McNatty, K.P., McNeilly, A.S., Monget, P., Monniaux, D., Viñoles, C., Webb, R. (2011) Regulation of folliculogenesis and the determination of ovulation rate in ruminants. . Reprod Fertil Dev 23, 444-467

Schams, D., Amselgruber, W., Einspanier, R., Sinowatz, F., Gospodarowicz, D. (1994) Localization and tissue concentration of basic fibroblast growth factor in the bovine corpus luteum. Endocrine 2: 907-912

Schuster, V.L. (1998) Molecular mechanisms of prostaglandin transport. Ann Rev Physiol 60 (1), $221-242$

Sen, A., Browning, J., Inskeep, E.K., Lewis, P., Flores, J.A. (2004) Expression and Activation of Protein Kinase C Isozymes by Prostaglandin F $\alpha$ in the Early- and Mid-Luteal Phase Bovine Corpus Luteum. Biol Reprod 70 (2), 379-384

Sen, A., Choudhary, E., Inskeep, E.K., Flores, J.A. (2005) Effects of Selective Protein Kinase C Isozymes in Prostaglandin $2 \alpha$-Induced $\mathrm{Ca} 2+$ Signaling and Luteinizing Hormone-Induced Progesterone Accumulation in the Mid-Phase Bovine Corpus Luteum. Biol Reprod 72 (4), 976984

Shah, D.K., Menon, K.M.J., Cabrera, L.M., Vahratian, A., Kavoussi, S.K., Lebovic, D.I. (2010) Thiazolidinediones decrease vascular endothelial growth factor (VEGF) production by human luteinized granulosa cells in vitro. Fertil Steril 93 (6), 2042-2047

Shapiro, S.S., Wilk, M.B. (1965) An Analysis of Variance Test for Normality (Complete Samples). Biometrika 52 (3/4), 591-611

Sheffel, C.E., Pratt, B.R., Ferrell, W.L., Inskeep, E.K. (1982) Induced Corpora Lutea in the Postpartum Beef Cow. II. Effects of Treatment with Progestogen and Gonadotropins. J Anim Sci 54 (4), 830-836

Shirasuna, K., Jiemtaweeboon, S., Raddatz, S., Nitta, A., Schuberth, H.J., Bollwein, H., Shimizu, T., Miyamoto, A. (2010) Rapid accumulation of polymorphonuclear neutrophils in the corpus luteum during prostaglandin F2 $\alpha$-induced luteolysis in the cow. PloS One 7 (1), e29054 
Short, R.V. (1962) Steroids in the follicular fluid and the corpus luteum of the mare. A 'two-cell type' theory of ovarian steroid synthesis. J Endocrinol 24(1), 59-63

Silvia, W.J., Lewis, G.S., McCracken, J.A., Thatcher, W.W., Wilson, L. (1991) Hormonal regulation of uterine secretion of prostaglandin F2 alpha during luteolysis in ruminants. Biol Reprod 45 (5), 655-663

Siperstein, M. (1970) Regulation of cholesterol biosynthesis in normal and malignant tissues. Curr Top Cell Reg 2, 65-100

Smith, G.D., Sawyer, H.R., Mirando, M.A., Griswold, M.D., Sadhu, A., Reeves, J.J. (1996) Steady-state luteinizing hormone receptor messenger ribonucleic acid levels and endothelial cell composition in bovine normal- and short-lived corpora lutea. Biol Reprod 55 (4), 902-909

Stevenson, J.S., Pursley, J.R. (1994) Use of Milk Progesterone and Prostaglandin F2 $\alpha$ in a Scheduled Artificial Insemination Program. J Dairy Sci 77(6), 1755-1760

Stewart, D.R., aVandevoort, C.A. (1997) Simulation of human luteal endocrine function with granulosa lutein cell culture J Clin Endocrinol Metabol 82 (9), 3078

Stouffer, R.L. (2003) Progesterone as a mediator of gonadotrophin action in the corpus luteum: beyond steroidogenesis. Human Reprod Update 9 (2), 99-117

Strott, C. A., Cargille, C. M., Ross, G. T. \& Lipsett, M. B. 1970. The Short Luteal Phase. J Clinc Endocrin Metabol, 30,246-251.

Sugino, N., Telleria, C.M., Gibori, G. (1997) Progesterone inhibits 20a-hydroxysteroid dehydrogenase expression in the rat corpus luteum through the glucocorticoid receptor. Endocrinology 138 (10), 4497-4500

Suzuki, T., Sasano, H., Kimura, N., Tamura, M., Fukaya, T., Yajima, A., Nagura, H. (1994) Physiology: Immunohistochemical distribution of progesterone, androgen and oestrogen receptors in the human ovary during the menstrual cycle: relationship to expression of steroidogenic enzymes. Human Reprod 9 (9), 1589-1595

Tanabe, T.Y., Hann, R.C. (1984) Synchronized Estrus and Subsequent Conception in Dairy Heifers Treated with Prostaglandin F2 $\alpha$. I. Influence of Stage of Cycle at Treatment. J Anim Sci 58 (4), 805-811

Tang, T., Lord, J., Norman, R., Yasmin, E., Balen, A. (2010) Insulin-sensitising drugs (metformin, rosiglitazone, pioglitazone, D-chiro-inositol) for women with polycystic ovary syndrome, oligo amenorrhoea and subfertility. Cochrane Database of Syst Rev 4

Tang, Y.C., Williams, B.R., Siegel, J.J., Amon, A. (2011) Identification of aneuploidy-selective antiproliferation compounds. Cell 144 (4), 499-512 
Tosca, L., Chabrolle, C., Uzbekova, S., Dupont, J. (2007) Effects of Metformin on Bovine Granulosa Cells Steroidogenesis: Possible Involvement of Adenosine 5' MonophosphateActivated Protein Kinase (AMPK). Biol Reprod 76 (3), 368-378

Tosca, L., Crochet, S., Ferré, P., Foufelle, F., Tesseraud, S., Dupont, J. (2006) AMP-activated protein kinase activation modulates progesterone secretion in granulosa cells from hen preovulatory follicles. $J$ Endocrinol 190 (1), 85-97

Tosca, L., Froment, P., Solnais, P., Ferré, P., F, F., Dupont, J. (2005) Adenosine 5'Monophosphate-Activated Protein Kinase Regulates Progesterone Secretion in Rat Granulosa Cells. Endocrinology 146 (10), 4500-45113

Townson, D.H., O'Connor, C.L., Pru, J.K. (2002) Expression of Monocyte Chemoattractant Protein-1 and Distribution of Immune Cell Populations in the Bovine Corpus Luteum Throughout the Estrous Cycle. Biol Reprod 66(2), 361-366

Tsai, S.J., Wiltbank, M.C. (1998) Prostaglandin F2alpha regulates distinct physiological changes in early and mid-cycle bovine corpora lutea. Biol Reprod 58 (2), 346-352

Viollet, B., Guigas, B., Sanz, G.N., J., L., Foretz, M., Andreelli, F. (2012) Cellular and molecular mechanisms of metformin: an overview. Clin Sci 122, 253-270

Walles, B., Gröschel-Stewart, U., Kannisto, P., Owman, C., Sjöberg, N.O., Unsicker, K. (1990) Immunocytochemical demonstration of contractile cells in the human ovarian follicle.

Experientia 46 (7), 682-683

Wiltbank, M.C., Belfiore, C.J., Niswender, G.D. (1993) Steroidogenic enzyme activity after acute activation of protein kinase (PK) A and PKC in ovine small and large luteal cells. . Mol Cell Endocrinol 97 (1), 1-7

Wiltbank, M.C., Diskin, M.G., Niswender, G.D. (1990) Differential actions of second messenger systems in the corpus luteum. J Reprod Fertil Supplement 43, 65-75

Wiltbank, M.C., Guthrie, P.B., Mattson, M.P., Kater, S.B., Niswender, G.D. (1989) Hormonal regulation of free intracellular calcium concentrations in small and large ovine luteal cells. Biol Reprod 41 (4), 771-778

Wiltbank, M.C., Ottobre, J.S. (2003) Regulation of intraluteal production of prostaglandins. Reprod Biol Endocrinol 1 (91)

Wiltbank, M.C., Shiao, T.F., Bergfelt, D.R., Ginther, O.J. (1995) Prostaglandin F2 alpha receptors in the early bovine corpus luteum. Biol Reprod 52 (1), 74-78

Wong, A., Howie, J., Petrie, J., Lang, C. (2009) AMP-activated protein kinase pathway: a potential therapeutic target in cardiometabolic disease. Clin Sci 116, 607-620 
Wright, M.F., Bowdridge, E., McDermott, E.L., Richardson, S., Scheidler, J., Syed, Q., Bush, T., Inskeep, E.K., Flores, J.A. (2014) Mechanisms of Intracellular Calcium Homeostasis in Developing and Mature Bovine Corpora Lutea. Biol Reprod 90 (3), 55

Yamamoto, D., Hayashi, M., Matsui, M., Miyamoto, A. (2004) PGF $_{2 \alpha}$ stimulates nitric oxide synthase (NOS) expression in endothelial cells co-cultured with luteinized, but not lutenizing granulosa cells: a possible implication of NO in acute blood flow increase during luteolysis. Biol Reprod 71142 (Abstract 218)

Yamashita, H., Kamada, D., Shirasuna, K., Matsui, M., Shimizu, T., Kida, K., Berisha, B., Schams, D., and Miyamoto, A. (2008) Effect of local neutralization of basic fibroblast growth factor or vascular endothelial growth factor by a specific antibody on the development of the corpus luteum in the cow. Mol Reprod Dev 75 (9), 1449-1456

Yoshioka, S., Abe, H., Sakumoto, R., Okuda, K. (2013) Proliferation of Luteal Steroidogenic Cells in Cattle. PLoS ONE 8 (12)

Zoller, L.C., Weisz, J. (1979) A quantitative cytochemical study of glucose-6-phosphate dehydrogenase and $\Delta 5$-3 $\beta$-hydroxysteroid dehydrogenase activity in the membrana granulosa of the ovulable type of follicle of the rat. Histochem 621 (2), 25-135 